University of Texas Rio Grande Valley

ScholarWorks @ UTRGV

Political Science Faculty Publications and

Presentations

8-17-2018

\title{
Industrial Structure and Political Outcomes: The Case of the 2016 US Presidential Election
}

Thomas Ferguson

Paul D. Jorgensen

The University of Texas Rio Grande Valley

Jie Chen

Follow this and additional works at: https://scholarworks.utrgv.edu/pol_fac

Part of the Political Science Commons

\section{Recommended Citation}

Ferguson T., Jorgensen P., Chen J. (2018) Industrial Structure and Political Outcomes: The Case of the 2016 US Presidential Election. In: Cardinale I., Scazzieri R. (eds) The Palgrave Handbook of Political Economy. Palgrave Macmillan, London. https://doi.org/10.1057/978-1-137-44254-3_11

This Article is brought to you for free and open access by the College of Liberal Arts at ScholarWorks @ UTRGV. It has been accepted for inclusion in Political Science Faculty Publications and Presentations by an authorized administrator of ScholarWorks @ UTRGV. For more information, please contact justin.white@utrgv.edu, william.flores01@utrgv.edu. 


\title{
INDUSTRIAL STRUCTURE AND POLITICAL OUTCOMES: THE CASE OF THE 2016 US PRESIDENTIAL ELECTION
}

\author{
Thomas Ferguson, Paul Jorgensen, and Jie Chen ${ }^{*}$
}

A version of this paper has appeared in I. Cardinale and R. Scazzieri (Eds.), The Palgrave Handbook of Political Economy, London, Palgrave Macmillan, 2018

\section{Introduction}

In early 2015, two scholars sat down to analyze the just completed 2014 Congressional elections. In contrast to mainstream commentators, they were not chiefly intrigued by the Republican gains in Congress or the widespread dissatisfaction with President Obama's economic policies that almost everyone agreed had helped cause that disaster for the president's party. ${ }^{1}$ Instead, after pouring over state by state election returns, they drew a radically different lesson: the American political system was coming apart at its seams.

The scholars knew that voter turnout typically falls off in mid-term elections. But the extent of the decline in 2014 astonished them. The major parties appeared to be breaking down as mass organizing vehicles:

2014 was fundamentally a democratic debacle. It likely heralds a new stage in the disintegration of the American political order....Focus on changes in turnout between presidential elections and the next off-year election. Across the whole sweep of American history, the momentous dimensions of what has just happened

\footnotetext{
* Thomas Ferguson is Professor Emeritus at the University of Massachusetts, Boston, Director of Research at the Institute for New Economic Thinking, and Senior Fellow at Better Markets; Paul Jorgensen is Assistant Professor of Political Science at the University of Texas Rio Grande Valley; Jie Chen is University Statistician at the University of Massachusetts, Boston.

The authors thank Roberto Scazzieri and Ivano Cardinale for their patience and friendly assistance. They are also very grateful to Francis Bator, Walter Dean Burnham, Robert Johnson, William Lazonick, Benjamin Page, Servaas Storm, Roger Trilling, and Peter Temin for many discussions and advice. They are particularly indebted to Page and Trilling for detailed editorial suggestions. Thanks also to the Institute for New Economic Thinking for support of data collection. Earlier versions of the paper were presented at the Institute for New Economic Thinking's conference in Edinburgh, Scotland, and published as Working Paper No. 66 of the Institute; and a conference organized by the Accademia Nazionale dei Lincei in Rome. It is worth emphasizing that the paper represents the views of the authors and not any of the institutions with which they are affiliated.
} 
stand out in bold relief. The drop off in voting turnout from the presidential election of 2012 to 2014 is the second largest of all time -24 percentage points...the decline is broad and to levels that boggle the mind - rates of voting that recall the earliest days of the 19th century, before the Jacksonian Revolution swept away property suffrage and other devices that held down turnout. Turnout in Ohio, for example, fell to 34 percent - a level the state last touched in 1814, when political parties on a modern model did not exist and it had just recently entered the Union. New York trumped even this: turnout in the Empire State plunged to 30 percent, almost back to where it was in 1798 , when property suffrage laws disenfranchised some 40 percent of the citizenry. New Jersey managed a little better: turnout fell to 31 percent, back to levels of the 1820s. Delaware turnout fell to 35 percent, well below some elections of the 1790s. In the west, by contrast, turnout declined to levels almost without precedent: California's 33 percent turnout appears to be the lowest recorded since the state entered the union in 1850. Nevada also hit a record low (28 percent), as did Utah at 26 percent (for elections to the House) (Burnham and Ferguson, 2014).

If there was any good news, it was decidedly bitter sweet: "[T]he sharp plunge in turnout elsewhere helped achieve a milestone of sorts: regional differences between the South and the rest of country just about vanished, for the first time since perhaps 1872, when the Union army still occupied much of the old Confederacy."

The Republicans seemed ascendant; they had just won back control of the Senate. But the analysts believed that the vacuum forming at the heart of the party system spelled big trouble for both major political parties: "though Republicans jubilate now, the trend is probably as threatening to them as it is to the Democrats. The reason is stark: Increasing numbers of average Americans can no longer stomach voting for parties that only pretend to represent their interests."

With an eye on Hillary Clinton's looming presidential candidacy, the scholars laid down a very specific caution, derived from their assessment of the Obama administration's economic record and the Party's top-heavy dependence on super rich megadonors.

Though some Democrats try to sugarcoat the dismal facts by focusing on changes since 2009, when the President assumed office, the truth is that the fruits of the recovery have gone lopsidedly to the very richest Americans. Wall Street and the stock market boom, but wages continue to stagnate, and unemployment remains stubbornly high...The administration's continuing efforts to court Wall Street, along with its reluctance to sanction even flagrant misconduct by prominent financiers just pour salt into these wounds....2014 suggests that the Democrats' ability to retain any mass constituency at all may now be in question. The facts of globalization, top-heavy income inequality, and the worldwide tendency toward austerity may just be too much for a party that is essentially dominated by segments of the 1 percent but whose legacy appeal is to average Americans... Right now Hillary Clinton's strategists appear to be pinning their hopes on firing up another ritualized big money-led coalition of minorities and 
particular groups instead of making broad economic appeals. That hope might perhaps prove out, if the slow and very modest economic recovery continues into 2016, or the Republicans nominate another Richie Rich caricature like Mitt Romney, who openly mocks the poorest $47 \%$ of the electorate. But exit surveys showed that in 2014 many women voters thought economic recovery and jobs were top issues, too (Burnham and Ferguson, 2014).

\section{The Trump Puzzle}

In 2016 the Republicans nominated yet another super-rich candidate - indeed, someone on the Forbes 400 list of wealthiest Americans. But pigeonholing him as a Romney-like Richie Rich was not easy. Like legions of conservative Republicans before him, he trash talked Hispanics, immigrants, and women virtually non-stop, though with a verve uniquely his own. He laced his campaign with barely coded racial appeals and in the final days, ran an ad widely denounced as subtly anti-Semitic. ${ }^{2}$ But he supplemented these with other messages that qualified as true blockbusters: In striking contrast to every other Republican presidential nominee since 1936, he attacked globalization, free trade, international financiers, Wall Street, and even Goldman Sachs.

"Globalization has made the financial elite who donate to politicians very wealthy. But it has left millions of our workers with nothing but poverty and heartache. When subsidized foreign steel is dumped into our markets, threatening our factories, the politicians do nothing. For years, they watched on the sidelines as our jobs vanished and our communities were plunged into depression-level unemployment."

In a frontal assault on the American establishment, the Republican standard bearer proclaimed "America First." Mocking the Bush administration's appeal to "weapons of mass destruction" as a pretext for invading Iraq, he broke dramatically with two generations of GOP orthodoxy and spoke out in favor of more cooperation with Russia. He even criticized the "carried interest" tax break beloved by high finance. His campaign's outreach to blue collar workers was so effective that it provoked Hillary Clinton into a gaffe about "deplorables" remarkably similar to Mitt Romney's famous outburst four years earlier. ${ }^{4}$

In the end, Donald Trump accomplished perhaps the greatest upset in American political history. With essentially all experts agreeing that he was politically dead, and many Republicans turning their backs on his campaign, he won more than half of all voters with a high school education or less (including $61 \%$ of white women with no college), almost two thirds of those who believed life for the next generation of Americans would be worse than now, and seventy-seven percent of voters who reported their personal financial situation had worsened since four years ago. ${ }^{5}$ As the stock market rocketed upward the next morning instead of tanking as virtually all talking heads in the media had predicted if Trump somehow prevailed, elites and many ordinary citizens around the world felt the ground slipping beneath their feet. On the heels of the United Kingdom's stunning vote in June to exit the European Union, which triggered another surprise short run economic upturn, it was all too much: some new and uncanny force seemed loose in the world. 
Given the new regime's stunning, at times almost hallucinatory, whirl of personnel switches, out of right field cabinet appointments, Oval Office tweets over the head of establishment media, loudly advertised breaks with precedent, and dramatic policy reversals, both real and claimed, the two scholars' conclusion that "the American political universe is being rapidly reshaped by economic and cultural crisis into something distinctly different" now seems almost trite (Burnham and Ferguson, 2014). But even a casual reading of the world press and the international scholarly discussion reveals an enormous divergence of views about the roots of this transformation as well as what actually happened in the 2016 election (Crotty, 2017).

Some of the perplexity arises from what at times amounts to a multiple personality disorder afflicting the new administration. A few incidents in the campaign foreshadowed this, but the syndrome became obtrusive as the new leader grasped the reins of power. Even in normal times, political coalitions in America are messy around their edges, because they are built up out of elements that rarely cohere completely. But we are not in normal times. The Trump campaign was born in singularity: a billionaire candidate whose fundamental economic strategy as he emerged from a succession of hairbreadth escapes from insolvency rested on transforming himself into a worldwide brand name and then franchising that, thus avoiding big capital commitments. In the crunch, however, as we will show, name recognition could not substitute for real money: first as he accepted the Republican nomination and then again in the late summer of 2016, his solo campaign had to be rescued by major industries plainly hoping for tariff relief, waves of other billionaires from the far, far right of the already far right Republican Party, and the most disruption-exalting corners of Wall Street.

The end of all vestiges of a one-man campaign had fateful consequences. The diverse investor blocs ranging themselves behind the new regime swelled but did not unify. Their only real point of agreement was that they preferred Trump to Hillary Clinton. After the election, the soaring stock market and influx of free market crusaders, including many former lobbyists, plumping for lower taxes, deregulation, and smaller government (aside, of course, from military expenditure) did win more admirers for the administration - for a time. An increasingly receptive business community, for example, showered record breaking amounts of cash on the inauguration festivities.

Yet even as financiers from the very same Goldman Sachs firm that Trump had so recently denounced flocked to senior White House slots, Trump himself continued to cling to notions of mobilizing blue collar workers. He put Steve Bannon, who championed this idea, in the White House and even, for a while, on the National Security Council. The incoming President electrified millions of Americans with tweets critical of Boeing, General Motors, and other giant businesses. He also organized meetings with union leaders. Spurning Democratic leaders' calls for all-out "Resistance," many trade union heads in construction, the electrical industry, and sectors of manufacturing hurt by free trade responded enthusiastically. Other more suspicious union chiefs felt boxed in by Trump's obvious popularity within their ranks. Democrats and even many Republicans feared that his much talked about pledges to boost infrastructure spending might become the basis of a new political realignment in which traditional Democratic constituencies played key roles. ${ }^{6}$ 
The ghost of Juan Peron, however, vanished almost as fast as it appeared. Forced to make a choice, the President opted to nominate a fast food executive with a notoriously anti-union record as the next Secretary of Labor. The nominee gushed enthusiastically about rolling back the Obama administration's rules - which, in contrast to so much else it did in the field of economic regulation, represented real, effective measures to protect low wage workers against wage theft and violations of minimum wage laws. The resulting scrutiny led to a pitched battle and an embarrassing withdrawal by the nominee. His replacement was less controversial, but the credibility of any courtship of labor was in tatters (Block, 2017).

Similar zig-zags marked many other areas of policy, as internationally oriented business groups battled the champions of economic nationalism. The President repudiated the Trans-Pacific Trade Agreement and another accord under negotiation with Europe, but he moved slowly on the North American Free Trade Agreement (NAFTA). He also took his time implementing proposals for tariffs, though every small step he and his advisors took in that direction sent shockwaves around the world. The same slow motion shuffle befell his campaign's signature proposal for a wall on the Mexican border: there was talk, but little action. On NATO, policy toward the Middle East, Russian, Iran, and US alliances with Pacific area countries such as Japan and Korea, the administration was plainly at war with itself, to the consternation of many U.S. allies, who were dismayed to discover that whatever "America First" meant, the taxi meter was running and they would have to ante up more for defense. As Steve Bannon exited the White House, amid a storm of controversy in the wake of the Charlottesville street clashes, the President reversed his own long held personal views, accepted the advice of his internationalist advisers, and decided to stay in Afghanistan.

More fatefully, the administration's initial efforts to block immigration by executive order were rejected by the courts and roused widespread indignation. They disgusted many Americans, who were repelled by what they perceived as arrant prejudice and barely disguised racism. Executives from many high tech companies, long reliant on steady streams of inexpensive foreign engineers, protested, as did other prominent business figures.

The administration slid deeper into trouble when it caved in to pressure to make repealing the Obama administration's Affordable Care Act its first priority instead of swiftly passing legislation on infrastructure or broader tax reform. That opened enormous fissures between insurers and hospitals on one side and the Koch-led conservatives whose priority was lower taxes, and who had heavily bankrolled Congressional Republicans. It also directly threatened vast numbers of voters, whose lives sometimes literally depended on the program. When the Senate refused to go along, the whole effort collapsed abjectly.

The President quarreled in public with Republican Congressional leaders. He shocked even some of them when he insisted that all the contending protest groups in Charlottesville occupied the same moral level. After he pardoned a former Arizona sheriff who had boasted about his harsh treatment of immigrants, an eerie chill set in between the President, Capitol Hill Republicans, and even some members of the Cabinet and White House staff. Then, all of a sudden, the President started talking to Democratic leaders about a deficit deal, to the astonishment of everyone concerned. But that, too, 
turned out to be a mirage, as the administration quickly turned to Republican-only tax "reform" aimed at helping corporations and the wealthy.

\section{Election Shapers? Comey and the Russians}

A record of campaigning and governing as crazy quilted as Trump's guarantees that reasonable people will assess some facts differently. But virtually from the moment Trump squeaked through on election night, all discussion turned highly partisan. ${ }^{7}$ Hillary Clinton and other leading Democrats called for all out "Resistance" amid waves of grass roots protests to the new regime. As they sounded the tocsin, they pressed two explosive theories of her narrow loss alongside their criticism of the media's preoccupation with her emails. The first traced it to Russian hacking efforts that led to the publication (by WikiLeaks) in the run up to the Democratic Convention of embarrassing Democratic National Committee (DNC) emails and later, in October, emails from top Clinton adviser John Podesta and the Center for American Progress that he had founded. ${ }^{8}$

The second pinned the reversal on the October $28^{\text {th }}$ announcement - just days before the election - by then Federal Bureau of Investigation Director James Comey that the Bureau was reopening its earlier investigation into Clinton's use of a private email server while Secretary of State. Although Comey subsequently informed Congressional leaders that his original decision not to prosecute would stand, Clinton and many other analysts contend that the announcement fatally damaged her credibility (Clinton, 2017).

Discussions of possible Russian attempts to influence the election had figured in a few news reports media since the late spring of 2016. But within weeks after the election both the Comey and the Russian stories were swept up into a much bigger and far more ideologically charged narrative that soon resounded around the world. The allegations about Russian influence dramatically broadened. A wave of leaks from unnamed national security personnel suggested that key people in Trump's entourage, including incoming National Security Adviser Daniel Flynn, a former Army Lieutenant General whom President Obama had fired as head of the Defense Intelligence Agency, had improperly cooperated with the Kremlin, possibly even violating the law. Stories also appeared relating how Republican Congressional leaders had resisted efforts by senior Obama administration officials to publicize allegations about the ties to Russia before the election. ${ }^{9}$

In early January the Office of the (outgoing) Director of National Intelligence released a declassified version of a secret evaluation drafted and coordinated by the FBI, the Central Intelligence Agency (CIA), and the National Security Agency (NSA). Its title page bore the legend "ICA Intelligence Community Assessment." document was widely heralded as representing the unanimous view of the entire American intelligence establishment. But this was not true. The report was in fact the product of a specially assembled team of analysts from the three agencies whose work was not circulated to the rest of the intelligence community. ${ }^{11}$ Almost a third of the document concentrated on broad brush criticism of "Russian TV," whose audience in the US is minuscule. The NSA, which controls the equipment used for electronic 
eavesdropping and thus should enjoy a uniquely authoritative position, was less confident than the CIA and the FBI, but agreed with the report's conclusion that a Russian campaign "aspired to help President elect Trump's chances of victory."12

The new conclusion represented a quantum escalation in claims; as late as October 31, "F.B.I. and intelligence officials" maintained that the DNC hacking "was aimed at disrupting the presidential election rather than electing Mr. Trump" (Lichtblau and Meyers, 2016).

Ever more extraordinary revelations cascaded on top of one another. New leaks revealed that the copy of the report given to the President contained a two-page summary of sensational claims about links between the Russian government and Trump that the intelligence chiefs admitted they could not verify. A "dossier" said to have been compiled by a former British intelligence agent who was a key source for many of those allegations quickly appeared in the press, touching off a worldwide firestorm. Not for many months did it become clear that the dossier actually had grown out of a research project originally commissioned by Republican opponents of Trump in the primaries; this was at first financed by a news site supported by Paul Singer, a prominent Wall Street financier, before being taken over by lawyers representing the Clinton campaign and the Democratic National Committee (Vogel and Haberman, 2017). Other claims said to derive from other European intelligence services were added to the mix, along with reports that DNC personnel had sought derogatory information on Trump from sources in Ukraine. $^{13}$

Several Congressional committees and at least one federal grand jury are currently investigating these matters. We see no reason to try to anticipate their conclusions, though the revelation that the Clinton campaign and the Democratic National Committee payed for part of the dossier must inevitably raise many new questions (Entous et al., 2017a). For this paper, only a few key points require notice. Firstly, that great powers mix in politics and elections in other countries should not be news. Both the US and many other countries have plainly done this many times - one thinks, for example of the now well documented US interventions in Italy, France and other countries in the early days of the Cold War. This sort of thing is now virtually institutionalized among the major powers. Indeed, several of the social media companies which played major roles in the Republican campaign are known to have sought and sometimes obtained contracts from the US or UK to work on elections or public opinion abroad, while many pollsters affiliated with the Democrats also work around the world, in the past including even elections in Russia. ${ }^{14}$ Many, though not all, such operations garner support from various government agencies, sometimes backstage but often quite in the open. ${ }^{15}$

Secondly, the use of internet and social media to reach across borders was virtually inevitable as soon as the technology developed to do it. The utility of these new forms of communication to bypass establishment media in the United States and some other countries (such as Italy and the UK) is now well documented, if variously assessed. That technology mostly developed alongside the rise of giant "platform" companies, such as Google and Facebook; it is mostly Made in America and centered heavily in Silicon 
Valley, though other countries, including Russia and China, certainly have also built up formidable capabilities. This is a point we shall return to below.

We note that some language of the original NSA, FBI, and CIA report is intriguingly guarded. It alludes to a campaign that "aspired" to help the Trump campaign to victory. ${ }^{16}$ That language brings to mind Robert Browning's famous line about the difference between a man's reach and his grasp. Whatever hopes Vladimir Putin or any oligarch may have entertained, the Russians had no special insight not reflected in American polls or betting markets (which are now widely accepted as good guideposts to conventional wisdom about election probabilities). ${ }^{17}$ Trump's win came as a worldwide shock; on Election Day his own polls showed him a likely loser, as did betting markets (Green, 2017). Like everywhere else, television networks in Russia had been preparing audiences for a Clinton victory. ${ }^{18}$ Whatever Flynn, Jared Kushner, or anyone else said to Russian officials before or after the election, any outside power meddling in the election could at best only have been picking up an option on defeating Clinton that was monumentally out of the money.

Throughout the campaign Trump consistently trailed Hillary Clinton in the polls, usually by substantial margins. In Paul Manafort's brief stint as Trump's campaign manager, save for the usual momentary bounce after the Republican Convention, the campaign's fortunes went from bad to worse, admittedly often for reasons that could hardly be laid at Manafort's door. When Steve Bannon, Kellyanne Conway, and the bloc of celebrated far right investors we discuss below jumped in to salvage things in midAugust, 2016, the campaign looked doomed. The most likely outcome any outside force could reasonably expect at that time was to embarrass (and seriously rile up) the prohibitive favorite, Hillary Clinton.

The dueling narratives about Putin and Comey, however, require some comments. First of all they do not cohere very well. Indeed, they come close to contradicting each other. There is plenty of material on the record, for example, to show that Comey knew of the misgivings of the other intelligence agencies when he dropped his October $28^{\text {th }}$ bombshell. But the Director of the FBI was certainly not in league with Vladimir Putin. We look forward to the investigating committees' explanations of why he breached the long-standing protocol that the FBI did not comment on investigations as elections approach, while declining to publicize the developing investigation into ties between the Trump campaign and Russia. We are equally curious about the many reports of dissension within the FBI and agents' complaints to senior Republican politicians advising Trump. These are especially troubling given John Podesta's public suggestion that elements within the Bureau may have hoped to elect Trump and Rudolph Giuliani's suggestive remarks on several occasions. ${ }^{19}$ The inquiry also needs to consider the broader process of politicization at work within the US intelligence community, since - most unusually - former agency heads issued clashing public endorsements of the major party candidates.

We think, however, that the evidence that either Comey or the Russians (or both) clearly cost Clinton the election is less clear-cut than often asserted. Moreover, no matter how one assesses these possibilities, focusing excessively on them misses the most important questions about the election. 
All versions of the Russian story, for example, seem inconclusive, though one the claims about internet trolling - is extremely difficult to assess, since virtually all data has been withheld from the public and leaked selectively by obviously interested parties. Let us set aside all arguments about the hackings themselves and focus first on the effects of the major email leaks. In March, Wikileaks had put on line a searchable file of Hillary Clinton's emails from her private email server while serving as Secretary of State. Those had been obtained via Freedom of Information requests. Later Julian Assange had trumpeted a forthcoming series of revelations regarding Clinton. Stories had also appeared about Russian efforts to penetrate Democratic National Committee emails. Some emails leaked into the press in mid-June; a source claiming to be "Guccifer 2.0" claimed credit, though another mysterious website, DC Leaks, also began posting documents. ${ }^{20}$ But the main drops came a month later. WikiLeaks began unveiling DNC emails in large numbers on July $22^{\text {nd }}$, just after the Republican Convention and immediately ahead of the Democratic conclave. Trump's modest post-convention bounce quickly melted away and Clinton kept going up in the polls for weeks. Her ascent was so marked that many observers, including, eventually, Donald Trump, concluded that unless his campaign drastically changed course, the election was all but over. That her ascension may have owed more to Trump's own bizarre campaign tactics than anything she did is irrelevant. The point is, she rose. By the time October rolled around, the earlier wave of emails was very old news for most voters. They cannot have turned the tide in favor of Trump.

By contrast, the release of the bulk of the Podesta emails at least comes closer to the moment Clinton flamed out. They were let go on a rolling basis starting on October $7^{\text {th }}$. But several major stumbling blocks stand in the way of the notion that they played a major role in turning the election around.

Older voting research typically argued that most voters making up their minds at the last minute came from the ranks of those paying the least attention to news and campaigns and with little interest in politics. This view is now increasingly contested, but more late deciders than not appear to resemble the older stereotype (Brox and Giammo, 2009). This makes strong claims somewhat problematic right off the bat. There is a real question about the sheer news value the story had for most Americans. For sure, within the Beltway and the Clinton campaign, the messages and doings of John Podesta and his lobbyist brother, along with the unvarnished opinions of Clinton's campaign managers about their candidate, ranked as a towering story. But outside of Washington, D.C., it is not obvious that that these details engrossed many voters, particularly in the battleground states.

Possibly any controversy that mentioned emails made problems for Clinton, but the point about attention is still material. The day the story broke, the competition for attention was ferocious: the infamous audio hit the airwaves in which Trump boasted about vulgar tactics he used to approach some women who interested him. The firestorm that triggered went on for days; indeed, in some sense, it has not died down to this day. We think it is likely that Trump's remarks on that subject intrigued far more voters than either the emails or a fresh claim about the Kremlin favoring Trump that also cracked the 
news that day. Most voters probably had never heard of either Podesta brother and likely cannot recognize them even today.

This claim is testable, albeit quite imperfectly, along with the closely related contention of some commentators that the destructive force of the stories derives from their cumulative effects over the month. Google Trends allows one to compare the relative volume of searches on topics by state and time. Tests would be sharper with access to absolute measures of interest rather than proportional scales and if one could easily separate out searches on Clinton from searches on her emails. But even the relative data indicate raise doubts. Searches on the "Podesta emails" and a few closely related search terms certainly do increase across the nation when the story breaks. In the US as a whole, there is a spike, followed by a steep and rapid decay. But the spike is hardly uniform. By far the largest happens - surprise - in the District of Columbia. Interest elsewhere is more modest, even in neighboring Virginia, though it ran higher there than in many other states. In the three non-southern consensus battleground states of Michigan, Wisconsin, and Pennsylvania, where Trump eked out crucial wins, it is substantially less: Relative scores are markedly lower, with interest in Wisconsin particularly anemic (41 against the Washington, D.C. top of 100), which is hard to square with claims that some emails had exceptionally powerful effects there. ${ }^{21}$ Interest in Florida and North Carolina, two other states that the Trump campaign also regarded as battleground states at least after mid-August (see below) was also modest and particularly anemic in areas in both that in the end broke relatively heavily for Trump. That Hillary Clinton's lead in the national polls was higher nine days after the Podesta emails story broke does not surprise us and confirms our misgivings.

In the final days of the campaign Trump did interject more references to the emails into his speeches. Interest revived modestly (in tandem, Google Trends suggests, with searches on Trump and women, which we believe likely dominated again). The flurry rises to about half the level of the earlier peaks - but the pattern of relatively lower interest in most battleground states persists, though the complexities of distinguishing between general searches on Clinton, on her emails, and on Podesta's make drawing firm conclusions impossible. By then, as will become clearer in a minute, many other things were happening that seem far more likely to impress large numbers of voters.

The assertions about Russian internet trolling and bots (trolls are alive; the bots are automatized) are harder to evaluate. They have never really been systematically detailed. In the strongest version, the Russians assisted the admittedly well organized and highly professional Trump internet campaign (or, in some tellings, the Republican National Committee) by flooding battleground states with fake news and messages relayed via internet "bots" - internet sites that automatically amplify by bouncing campaign messages, even though they may not even be located in the United States. Depending on who's talking, the aim was to identify likely Trump voters or discourage turnout on the Democratic side by means of negative messages. Less extreme accounts simply allege unspecified Russian internet support. ${ }^{22}$

We will return to this topic later in the paper, but a brief discussion can clarify issues that could otherwise cause trouble. Firstly, we concur that Russian capabilities in so-called "organic" internet messaging are well developed. It is also clear that the US and 
Russian intelligences services have been dueling for a long time, so that it would be surprising if Russian agencies or their cutouts working in this area simply sat out the US election. $^{23}$

But the central point is understanding how Trump could reach so far into traditional Democratic territory. And here we think the decisive factor is that the real masters of these black arts are American or Anglo-American firms. These compete directly with Silicon Valley and leading advertising firms for programmers and personnel. They rely almost entirely on data purchased from Google, Facebook, or other suppliers, not Russia. American regulators do next to nothing to protect the privacy of voters and citizens, and, as we have shown in several studies, leading telecom firms are major political actors and giant political contributors (Ferguson et al., 2013) (Ferguson et al., 2017). As a result, data on the habits and preferences of individual internet users are commercially available in astounding detail and quantities for relatively modest prices even details of individual credit card purchases.

The American giants for sure harbor abundant data on the constellation of bots, I.P. addresses, and messages that streamed to the electorate. But they have been very coy about releasing that data or making it available to independent researchers. It now seems reasonably clear that Facebook recognized that something unusual might be afoot in June of 2016 and, in contrast to the Democratic National Committee, went immediately to the FBI with the news. ${ }^{24}$ The company's subsequent public disclosures have clearly been grudging and piecemeal, with few details offered, though we now know that prominent Democrats repeatedly implored the firm to investigate and stop dismissing notions that nothing significant could have occurred (Entous et al., 2017b). The firm left it to other researchers to point out that the total "reach" of any effort undertaken by Russian actors should not be measured by the number of times Americans looked at the ads Facebook finally turned over to Congressional committees. Their sites also posted content, which users could share with their friends and acquaintances.

Testimony by tech company executives at a hearing before the Senate Intelligence Committee suggested that as many as 126 million Americans might have come into web contact with various ads on Facebook while another 20 million people may have been reached via Instagram. ${ }^{25}$ Another study that examined only a sliver of such sites suggested that literally millions of pages of content might in fact have been shared by users (Albright, 2017a). These numbers, however, need to be put in context: They represent a tiny fraction of the "33 trillion posts Americans saw in their Facebook news feeds between 2015 and 2017 ...Facebook reported that a quarter of the ads were never seen by anyone. And - with the average Facebook user sifting through 220 news-feed posts a day - many of the rest were simply glanced at, scrolled past and forgotten" (Ruffini, 2017).

In the absence of data transparency, we are reserved about all claims by Facebook, Twitter, Google, or anyone else about what ads they did or did not sell or the uses of the sites; we have trouble understanding why several Congressional committees were so slow to require full public disclosure of exact information, especially once the companies admitted that the ads already ran in public. For the same reason, we are cautious about assertions by Trump campaign workers that they did not find Twitter very 
useful, though that assertion is potentially very telling, since so many more bots are keyed to Twitter, rather than Facebook (LoBianco, 2017).

We take much more seriously the findings of empirical studies of overall election communication patterns by independent researchers who gathered their own data. Jonathan Albright has attempted to map the "ecology" of both left and right networks in several recent studies. His work emphasizes the unusually dense, ramified character of the right wing messaging networks that developed over the last few years: "to put it bluntly, 'right-wing' news is everywhere: Twitter accounts, Facebook pages, small issuebased websites, large news websites, Wordpress blogs, Google Plus (?), Pinterest pages, Reddit threads, etc." (Albright, 2016).

A Harvard study of the internet in the 2016 presidential election makes a similar point: "Our clearest and most significant observation is that the American political system has seen not a symmetrical polarization of the two sides of the political map, but rather the emergence of a discrete and relatively insular right-wing media ecosystem whose shape and communications practices differ sharply from the rest of the media ecosystem, ranging from the center-right to the left. Right-wing media were centered on Breitbart and Fox News, and they presented partisan-disciplined messaging, which was not the case for the traditional professional media that were the center of attention across the rest of the media sphere" (Faris et al., 2017).

Such studies suggest that stories hyping "the sophistication of an influence campaign slickly crafted to mimic and infiltrate U.S. political discourse while also seeking to heighten tensions between groups already wary of one another" by the Russians miss the mark. (Entous et al., 2017c). By 2016, the Republican right had developed internet outreach and political advertising into a fine art and on a massive scale quite on its own (Faris et al., 2017) (Albright, 2016). Large numbers of conservative websites, including many that that tolerated or actively encouraged white supremacy and contempt for immigrants, African-Americans, Hispanics, Jews, or the aspirations of women had been hard at work for years stoking up "tensions between groups already wary of one another." ${ }^{, 26}$ Breitbart and other organizations were in fact going global, opening offices abroad and establishing contacts with like-minded groups elsewhere. Whatever the Russians were up to, they could hardly hope to add much value to the vast Made in America bombardment already underway. Nobody sows chaos like Breitbart or the Drudge Report, as the New York Times documented in one Idaho town (Dickerson, 2017).

Some firms could add value though, but every one of them was as American as apple pie. With no publicity, the tech giants - Google, Facebook, Twitter - were all trying to muscle in on the richly rewarding arena of campaign consulting. Their aim was not to "weaponize" internet ads, in the ominous sounding term that analysts of Russian internet now throw around - their interest lay in monetizing them, just as they have restlessly tried to do in everything they engage in. Two scholars who analyzed these efforts describe how the companies went about this: "For example, these firms offer an extensive array of campaign services - including advising campaigns on everything from the content of ads and other communications to the specific groups they might benefit most from targeting, and how best to reach them... all three of these firms have 
dedicated partisan teams that work with campaigns. Staffers work with campaigns to guide advertising buys, boost engagement around online ads, and shepherd the use of their platforms" (Kreiss and McGregor, 2017).

The researchers" assessment that such services "were far more consequential in terms of the election outcome," with a "far greater reach than Russian bots and fake news sites" strikes us as spot on (Kreiss and McGregor, 2017). As Albright cautioned in an earlier study, "before we keep pointing fingers at specific countries and tweeting about companies "hacking the election," as well as to solve the scourge of "fake news," it might be good to look inward. By this, I mean we should start the quest for transparency in politics with a few firms based in New York City and Silicon Valley." ${ }^{27}$ We are confident that it will eventually become clear that Russian efforts were distributed over many platforms besides Facebook, making total expenditures appreciably higher. But they will still pale beside those of the US Alt Right networks and the Trump campaign's own investments, which were at once gigantic and carefully targeted (Gold and Dwoskin, 2017).

The notion that Republican vote suppression campaigns needed Russian assistance is particularly silly. It is almost laughable given the barely disguised pronouncements of so many Republican election officials in Michigan, Pennsylvania, Wisconsin, North Carolina and other states and - until efforts to smother turnout became controversial - the unguarded comments of Trump's own campaign (Wines, 2016) (Bump, 2017) (Barajas, 2016). ${ }^{28}$ Suggestions that internet campaigning was responsible for Clinton's poor showing in the crucial Detroit area are particularly difficult to accept, since about $40 \%$ of the city's population has no internet access, because they are too poor to interest the local telecom oligopoly (Rogers, 2017).

Not surprisingly, the evidence revealed thus far does not support strong claims about the likely success of Russian efforts, though of course the public outrage at outside meddling is easy to understand. The speculative character of many accounts even in the mainstream media is obvious. Several, such as widely circulated declaration by the Department of Homeland Security that 21 state election systems had been hacked during the election, have collapsed within days of being put forward when state electoral officials strongly disputed them (Greenwald, 2017), though some mainstream press accounts continue to repeat them. ${ }^{29}$ Other tales about Macedonian troll factories churning out stories at the instigation of the Kremlin, are clearly exaggerated. When reporters from Wired and CNN showed up to check, the major inspiration turned out to be Adam Smith and the spirit of free enterprise: out of work locals had discovered that they could monetize clicks on advertising sites. More than a few had tried out several candidates before discovering that Trump ads generated more clicks than anyone else's. ${ }^{30}$

The paid ads Facebook has disclosed were hardly on the scale one would expect for an all-out effort $(\$ 100,000)$, though (as noted above) their reach can be vastly extended by individual sharing and we expect more action on other platforms will turn up. A more serious problem for strong claims is timing, since the buys were scattered through 2015, 2016 and 2017 and across states, and appear to have focused often on states that had no chance of ever tipping in favor of Clinton. Subsequent revelations by Facebook underscore the importance of this issue, since more than half of its ads are 
admitted to have run after the election (Isaac and Shane, 2017). The Senate Intelligence Committee hearings produced truly microscopic numbers for putative Russian efforts directed at the key battleground states of Wisconsin, Pennsylvania, and Michigan: For Wisconsin, $\$ 1,979$, with all but $\$ 54$ dollars of this spent during the primary. Russian Facebook spending in the other two was even more minuscule: Pennsylvania absorbed all of \$823 and Michigan \$300 (Madrigal, 2017) (Ruffini, 2017). Unless Facebook discloses some vast new trove, the conclusion has to be that this was no full court press.

The few individual cases that have so far become public only increase one's skepticism. One episode in Texas ballyhooed as a direct effort to affect the election proves on examination to be flimsy indeed. This involved a series of rallies called in late October and early November, 2016 in favor of Texas Independence and against immigrants and Hillary Clinton (Bertrand, 2017). But the idea that such a campaign could help move a pro-Clinton state into Trump's column can only be described as harebrained: Texas was already solidly for Trump. The project's influence can be easily tested with Google Trends (and the election results in Texas); it made no discernible impact at all. ${ }^{31}$ Another widely touted case in Florida fails the same tests, though there at least a battleground state was involved (Collins et al., 2017).

These are all admittedly individual cases. More systematic assessments are hobbled by the slowness of American authorities and the Silicon Valley giants to release much data and by the entrance into the debate of various groups with obvious foreign policy axes to grind (Greenwald, 2017). More than a few studies have given up sifting through the welter of internet news and commentary in favor of resting identifications of sites as "Russian" or "Russian influenced" on the basis of views discussed that the analysts find politically distasteful. This leads to inflated measures of Russian influence that count websites that are plainly not Russian inspired at all, but simply nonmainstream or even, sometimes, it appears, simply critical of Likud Party interpretations of Israeli interests.

One careful and comprehensive assessment of internet messaging in the final ten days of the campaign has appeared, however, and its findings are eye-opening. The researchers attempted to measure the targeting of individual states by "tweets with junk news, links to unverified WikiLeaks pages, or links to Russian content (such as Russia Today or Sputnik)." They suggest that "when links to Russian content and unverified WikiLeaks stories are added to the volume of junk news, fully $32 \%$ of all the successfully catalogued political content was polarizing, conspiracy driven, and of an untrustworthy provenance." Then they deliver what they think is their punch line: "Average levels of misinformation were higher in swing states than in uncontested states, even when weighted for the relative size of the user population in each state"(Howard et al., 2017).

This study is instructive on several accounts. As the authors recognize, its measure of fake news clearly embraces far more than Russian sourced material; in all likelihood, most of what it counts is coming from the far right, mixed perhaps with some content originating from far left sources with no links to Russia. But what stands out is the quantitative evidence of how poorly all this content was actually targeted on swing states. The test the study performs is extremely weak: a comparison of the numbers of 
swing states above and below the US average. It finds somewhat more swing states rank above average in fake news.

A stronger test supports a strikingly different conclusion: As the figures quoted above in the Senate Intelligence Committee hearings suggest, in fact any targeting was very poorly executed. Swing states were not difficult to identify: many polls and news stories, not to mention the presidential campaigns themselves, talked of little else. If we lay aside quibbles about how many states really qualified as "swing" states and simply accept the study's measures, then a much more revealing test is easy to apply. Were targeting perfect, all the states identified as swing should stand at the very top of the fake news ranking. To the extent non-swing states crowd those states out, would-be targeters have missed their mark. In fact the essay's Table 2 testifies to a gang that can't shoot straight: the state with by far the heaviest dose of fake news was West Virginia, which was a lock for Trump. Most other states in the top rankings are also non-swing. By contrast, Wisconsin and other crucial states show near the bottom. The conclusion has to be that targeting was very poor; if you treated the question as a special case of an exam in American studies, then only 7 of the 16 swing states were correctly identified - a failing grade by most standards.

So much for Twitter. No comparably broad survey of Facebook has so far been published. What has been selectively leaked about isolated swing states on Facebook raises suspicions of cherry picking; serious targeting using Facebook, like Twitter, could not focus simply on one or two states. Doubts are increased by a carefully documented study of a sliver of the known sites. The author rightfully draws attention to the defects of simply using views of the ads, and his analysis of the sharing of various page contents is illuminating. But his time graph also shows a very large part of the effort came after the election. As he notes, the pattern suggests that many of the pre-election ads may indeed have attempted to influence voters, but the broader record he presents is consonant with the indifferent targeting revealed in the Twitter study (Albright, 2017a) (Timberg, 2017). Efforts to distort elections have to precede or coincide with Election Day; afterward the horse has left the barn.

Strong claims about the potency of relatively small-scale and poorly targeted internet appeals and propaganda also fit badly with the known facts of how political advertising reaches voters. In 2016 television, not the internet, was still the main source of campaign news for Americans. Several studies have attempted to compare the effectiveness of television ads versus internet advertising; in all of these, the amount of repetition necessary on average to change minds seems very high; the fact that as many as ten million Americans might have seen one or another ad sounds impressive but it is anything but conclusive (Allcott and Gentzkow, 2017) (Isaac and Shane, 2017). Even without making strong assumptions about rates of repetition, on the evidence thus far it seems likely that the number of minds changed or immobilized by any Russian trolls could not have been large by comparison with all the other sources bombarding voters.

The internet trails well behind TV, not just in use, but in effective influence. Surveys suggest that only $4 \%$ of American adults who use the web trust the information they get from social media "a lot"; a mere 30\% trust it even "some" (Mitchell et al., 2016). It is worth emphasizing that no matter how often one hears that the internet has 
divided Americans into single minded camps walled off from other points of view, much empirical evidence points in the opposite direction. The echo chamber claim overlooks the range and number of alternative views that retweets and messages from friends and acquaintances expose Americans to. In addition, the biggest increases in political polarization over the last decades occurred in the segments of the electorate that are least connected to the internet. ${ }^{32}$

One can always riposte that in an election this close, any feather tossed on the scales could prove decisive. That response makes more mathematical than practical sense, however. In the campaign's final days, feathers were flying everywhere - and virtually none were imported.

\section{The Comey Intervention.}

The initial evidence, for example, that Comey tipped the scales looked very compelling and continues to be widely repeated: A striking graph seemed to show Clinton's support collapsing immediately after his announcement. Some studies of Trump and Clinton's campaign echo this judgment. Eventually, however, it transpired that Clinton's polls started falling in surveys taken before but mostly not released until after the announcement (Cohn, 2016). Skeptics also observed that a highly publicized October $24^{\text {th }}$ notice of sweeping price hikes for health care insurance under President Obama's Affordable Care Act appeared to fit the data even better - and that this, too, was a development that Trump seized upon in his campaigning. Curiously, post-campaign studies devote virtually no attention to this health care setback, though Bill Clinton himself had gone off script earlier out of anxiety about the issue's potential importance. ${ }^{33}$

Since then much of the argument has been conducted in terms of how best to aggregate polls that did indeed appear to be turning before Comey spoke out. The problem is easy to state but hard to assess concretely. Evaluating individual polls is difficult and time-consuming (and often impossible, because their sponsors often reveal so little). Many analysts therefore simply average them all. But if you insist on aggregating polls on a rolling basis over several days, recognizing real turning points inevitably is very difficult. After their claims were challenged, some analysts who originally blamed Comey agreed that in principle some adjustments were necessary. Then they proposed "corrections" that reinstated, almost miraculously, their original conclusions. By contrast, a committee of the American Association of Public Opinion Research reached a negative verdict: It concluded that Comey's announcement "had an immediate, negative impact for Clinton on the order of 2 percentage points. The apparent impact did not last, as support for Clinton tended to tick up in the days just prior to the election" (Ad Hoc Committee, 2017).

The argument rages still. Our sympathies are firmly with the skeptics. Though no single indicator is likely to resolve such issues, it is striking that the price of winner-takeall contracts on a Trump victory doubled in the days ahead of Comey's announcement - a strong indicator that somebody's sentiment was changing. ${ }^{34}$ But we also believe that 
discussions of the election's final days have ignored a raft of other potentially important complicating factors.

Save for Clinton's own memoir and a handful of other discussions, most accounts blaming Comey are importantly skewed: Implicitly they assume the mass media were passive relay devices. That hardly does justice to the quantitative evidence of the media reaction: Empirical studies suggest that the media piled on when the news came out. Stories about Clinton's credibility and character crowded out all other themes related to her candidacy for more than a week (Patterson, 2016a).

This should put a different face on matters: Mass media hype of a dubious pronouncement by an FBI Director raises questions of another order. If the major media manufactured a mountain out of a hill, we would like to know why. A key question should be the balance struck between questions about each of the protagonists. In theory, the media could have lavished more attention on Comey's departure from FBI norms than old questions about Clinton. The stories bubbling up about discord within the FBI could have received more attention, instead of being virtually buried. These would inevitably would have raised questions about partisan intent, likely weakening whatever influence the episode had.

\section{Beyond the Russians and Comey}

An obvious background factor - that the Clinton campaign emphasized candidate and personal issues and avoided policy discussions to a degree without precedent in any previous election for which measurements exist - adds further complexity (Fowler et al., 2016). It pushes the inquiry back one critical stage: Why did the campaign say so little about policy, when articulated positions on appealing issues could have provided a base to fall back upon in adversity? We believe this question has a clear answer discussed below, and it has nothing to do with the FBI.

But the lame Clinton campaign and even its now-famous refusals to campaign in Wisconsin or buy earlier advertising in Michigan are not the only factors that likely helped Trump burst through the sound barrier at the end. The poll analysts who lovingly chronicle every twist and turn in surveys have mostly been strangely uninterested in exploring the extent to which vote suppression figured in the battleground states and some others where outcomes ran close, notably North Carolina. The omission is particularly odd given, as mentioned above, the disarming candor of key Republican election officials in so many states.

Analysts have also closed their eyes to another factor that surely had major effects on Democratic prospects in all three key non-southern battleground states that Clinton lost by a hairsbreadth -- Wisconsin, Michigan, and Pennsylvania. Each was the site of sweeping and successful anti-union drives led by employers and Republican politicians. As Table 1 indicates, all three rank at or near the very top of states showing declines in unionization rates between 2008 and 2016 - cliff-like drops that occurred while a Democratic President sat in the White House, controlling both the Labor and the Justice 
Departments. We do not find it mysterious that blue collar workers in those states might be a tad less enthusiastic about what many described as an Obama "third term" or perhaps even wonder what the Clinton Foundation was doing as the only institutions that protected their livelihood were destroyed or vastly weakened.

Table I About Here

Pundits and scholars alike have also closed their eyes to even the grossest facts about political money in the final days. Many campaign accounts implicitly repeat Trump's own nostrum that he was not dependent on outside money and take it for granted that he was running a lean campaign. We will show below that by October this was campaign hype, pure and simple.

\section{Follow the Money}

What happened in the final weeks of the campaign was extraordinary. Firstly, a giant wave of dark money poured into Trump's own campaign - one that towered over anything in 2016 or even Mitt Romney's munificently financed 2012 effort - to say nothing of any Russian Facebook experiments. The gushing torrent, along with all the other funds from identifiable donors that flowed in in the campaign's final stages should refocus debates about that period. (See Figure 1, below.) Maybe all that happened is that money talked, not least in the famous last ad invoking Soros, Blankfein, and Yellin apparently focused on the battleground states.

Figure 1 About Here

Bolstering suspicions that a wave of last minute money might actually be the most basic explanation for the Clinton collapse is a fact that virtually no analysts have reflected upon: Her late October fall in the polls was not unique. Democratic chances of taking the Senate unraveled virtually in lock step.

This was no accident, and here one can trace a clear green thread. Earlier in October, when Trump's case still appeared hopeless, Senate Republican Majority Leader Mitch McConnell and his entourage started pitching many famous businessmen and 
women. Hillary Clinton in the White House, ran their argument, would be awful, but losing control of the Senate would be Armageddon. McConnell, like most politicians, had a history of crying wolf, but by mid-October, polls and betting odds alike suggested that chances of the Republicans losing control of the Senate were excellent (Troyan and Schouten, 2016, Blumenthal, 2017, Isenstadt, 2016).

Nixon's Attorney General, John Mitchell, once famously quoted an old adage that when the going gets tough, the tough get going. In 2016, the tough, or at least the super-affluent, certainly got going. Our data show that yet another gigantic wave of money flowed in from alarmed business interests, including the Kochs and their allies, who were not actively supporting Trump. ${ }^{35}$ Officially the money was for Senate races, but our observation is that late-stage campaigning for down-ballot offices often spills over on to candidates for the party at large. It is much easier to cooperate with state and national party organizations and push the whole ticket, whatever poses individual Republican Senate candidates were striking. Statistically sorting out the joint impact of these two ocean swells is not possible given existing data, but one fact is very telling. For the first time in the entire history of the United States, the partisan outcome of Senate races coincided perfectly with the results of every state's presidential balloting (Enten, 2016).

The dual unravelling of the Democrats is apparent in polls and Iowa market contract prices. Figure 2 graphs the Iowa Electronic Market prices for winner-take-all presidential contracts against the prices of a contract on the combination of a Republican House and a Democratic Senate. Because almost nobody believed the Democrats could win back the House by then, variation in the Congressional contract reflects changes in perceptions of Democratic Senate prospects. The two declines very closely track each other, with the difference that Clinton, who had proportionately more money than many hapless Democratic Senate candidates, was able to scramble back.

Figure 2 About Here

The notion that Comey or even the Russians could be responsible for both collapses is outlandish. Something else must in large part have driven both outcomes. ${ }^{36}$ Parallel waves of money is the obvious explanation and our data show that both occurred precisely in the relevant time period. 


\section{Posing the Right Questions}

In an election as close as that of 2016, one could debate forever how all these factors played out, especially since big, nationally representative voter surveys are likely to mirror only imperfectly the peculiarities of a few battleground states. In the spirit of Sir Peter Medawar's dictum that science involves the art of the soluble, accordingly, we think that a far more fruitful approach is to alter the question.

It is time to focus on the dominating fact that became visible in the 2014 congressional elections: that American politics has strayed into some strange new Twilight Zone - and try to understand how this sovereign fact shaped the shocking outcome of the presidential election.

This task, in our view, requires framing clear answers to three questions. The first is what drove the Republican primaries so badly off script. At the start, for most observers, the dominant narrative was crystal clear: Jeb Bush would once again summon the legendary Golden Horde that had powered the campaigns of his brother and father and float to victory on a tidal wave of money. The Kochs and other well-heeled interests would promote challengers even further to the right, but in the end the "Kochtopus" would close ranks with the rest of the party after Jeb! won. Champions of the religious right and libertarians would also dip their toes into the water and try to fire up their supporters. They would shake, rattle, and roll and then, as they ran out of money, they would bow out with more or less grace. With surging hopes for a cabinet position or a slot on Fox News they would fall in with the great Republican Crusade against a Second Coming of the Clintons.

Obviously most of this never happened, though it is interesting to see how some of the also rans, notably the evangelicals, found paths to endorsing a nominee whose public comments about women suggested he was likely much more comfortable with Mary Magdalen 1.0 than the Virgin. ${ }^{37}$

The second question concerns the stunning course of the Democratic campaign. This is every bit as rivetingly mysterious as the Trump phenomenon: Anyone who predicted as the campaign got underway that a professed democratic socialist would win more than 13 million votes running against Hillary Clinton, would openly attack Wall Street's headlock on the Democratic Party on prime time TV, and actually win primaries in big industrial states like Michigan while sweeping through western caucuses, would have been laughed off the stage. The Sanders phenomenon needs a searching examination. We suspect it is every bit as important for the future as the outcome on the Republican side.

Finally comes the most immediate mystery of all: what explains the roller coaster course of the Trump campaign? How the real estate magnate breezed past the rest of the Republican field merits a closer look than it has so far received. Was his early success truly all owed to his celebrity candidacy or were other factors important? Did he really pay for the whole campaign himself, as he kept saying? And did he run on a shoestring? Are the oft-repeated claims that he enjoyed little support in Silicon Valley aside from Peter Thiel really true? 
Once he won the nomination, the main questions are two: Firstly, how much of the party consolidated around him and how did that affect the financing of the campaign? Was his candidacy still mostly self-financed or did Trump, Inc., begin selling shares? If so, who purchased them? Secondly, how did the Trump campaign climb out of the crater that it had dug itself into by midsummer? As late as August 14, 2016, Trump's chances appeared almost hopeless: you could buy a contract that would pay a hundred dollars in the event he won for twenty-two dollars on the Iowa Trading Markets Exchange.

But then something eerie happened. Conservative billionaire daughter Rebekah Mercer personally buttonholed Trump at a fundraiser. She advised him to stay in the race, but to fire Paul Manafort and turn over direction of the campaign to Steve Bannon and Kellyanne Conway (Green, 2017). Trump took her advice, and the rest is history. But what exactly did that dynamic duo do to bring about perhaps the greatest turnabout in American electoral history? If it wasn't just the Russians or Comey, what exactly was the recipe? A data processing miracle conjured up by Cambridge Analytica, the mysterious data firm at least partly owned by the Mercers that worked alongside Giles-Parscale, the Dallas digital outfit that had long worked for Trump? ${ }^{38}$ Or were there more fundamental flaws in Clinton's campaign that Bannon and Conway's strategy exploited - besides the confusion and restless infighting emphasized in some excellent post-election studies (Allen and Parnes, 2017) (Brazile, 2017)? Most importantly, did other powerful but less heralded forces work in the background with the new leadership to provide the campaign with the racer's edge? Forces that perhaps still figure importantly in the new administration?

\section{The Twilight Zone}

All efforts to grapple with these questions quickly run into a striking paradox one that betrays a revealing clue about the nature of the 2016 shock. In 2014, signs of a dramatic departure from business as usual could be read off voting returns, albeit in a very unconventional way: To perceive them, one had to look past the details of the partisan split and changes in seats to focus on voting turnout in a long term historical perspective.

2016 is very different. We agree with analysts who suggest that a finely textured analysis of the presidential vote can detect some far-reaching changes in the attitudes of some voters. But these alterations are mostly subtle. No matter how anyone slices and dices the election returns, it would be a stretch to claim that they add up to anything momentous enough to account for the stunning political shifts that are happening right in front of everyone's eyes. Neither turnout nor the partisan division of the vote at any level looks all that different from other recent elections. As several political scientists quickly proclaimed after the dust settled, signs of major change are virtually non-existent by the standards of election markers that conventional political science relies on. Indeed 2016's alterations in voting behavior are so minute that the pattern is only barely differentiated from 2012. If one considers only aggregate returns, the election that produced Trump and Sanders looks like a "remarkably ordinary election outcome, primarily reflecting partisan patterns familiar from previous election cycles" (Bartels, 2016) 
We think this is like trying to make sense of the last days of Pompeii while resolutely ignoring Mt. Vesuvius. So where is the decisive evidence of historic upheaval? This question has a simple answer in our view: Stop focusing simply on voting patterns and analyze the election in terms of the investment approach to political parties that we normally employ.

Essentially a method for investigating how industrial structures and social conflicts figure in political outcomes, this approach developed out of the broader literature on industrial structure fitfully advanced over several generations by such scholars as Gerschenkron, Kehr, Rosenberg, and Kurth. ${ }^{40}$ Its starting point is the acknowledgment that in most modern countries, political action is far more costly in terms of both time and money than classical democratic theories imagined (Ferguson, 1995a). As a consequence, popular control of the state depends on the extent to which ordinary citizens can bear those costs. Nothing metaphysical is implied here: to control the state citizens need to be able to share costs and pool resources easily. In practical terms, this requires functioning organizations - unions, neighborhood organizations, cooperatives, etc. - in civil society that represent them without enormous expenditures of time and money. There is one and only one guarantee of this: those organizations have to be controlled by and financially dependent on them. If existing parties are not controlled by voters, then they have to undertake the comparatively expensive process of running candidates of their own. To the extent that "secondary" organizations flourish, or the population directly invests its own resources in candidates, popular control of the state and effective mass political movements will flourish (Ferguson, 1995a).

Where investment and organization by average citizens is weak, however, power passes by default to major investor groups, which can far more easily bear the costs of contending for control of the state. These normally align in distinctive blocs arising out of historically specific patterns of industry structures (where "industry" embraces finance, mining, agriculture, and services alike). In most modern market-dominated societies (those celebrated recently as enjoying the "end of History"), levels of effective popular organization are generally low, while the costs of political action, in terms of both information and transactional obstacles, are high. The result is that conflicts within the business community normally dominate contests within and between political parties the exact opposite of what many earlier social theorists expected, who imagined "business" and "labor" confronting each other in separate parties. Few indeed are the labor movements today that can realistically expect to control parties of their own (Ferguson, 1995a).

Analyzing elections, accordingly, should begin with at least an implicit assessment of the state of mass organization. But the next step is a careful assessment of the industrial structure, particularly of large firms, followed by the application of the fundamental principle of the investment theory of partisan competition. Only candidates and positions that can be financed can be presented to voters. As a result, in countries like the US and, increasingly, Western Europe, political parties are first of all bank accounts. With certain qualifications, one must pay to play. Understanding any given election, therefore, requires a financial X-ray of the power blocs that dominate the major parties, with both inter- and intra- industrial analysis of their constituent elements. 
Such analysis normally embraces both institutional and personal factors. It brings into play a much broader "spectrum of political money" than just formal campaign spending (Ferguson, 2014a). In the US and some other developed countries, however, that last category bulks so large that breaking it down sheds real light on political dynamics. Indeed, the US may be in a class by itself in this regard.

We are the first to admit that analyzing campaign financing is astonishingly difficult, despite the surface transparency of the records. In federal elections in the US, two different streams of contributions are reported to two different government agencies - the Federal Election Commission and the Internal Revenue Service. Each of these agencies uses a different reporting system with radically different formats and disclosure deadlines (Ferguson et al., 2013). Almost the only thing the two bureaucracies have in common is their low level of zeal for ensuring that the money they track is reported with all the basic information required by law. That nonchalance and the lack of standardization makes scrutiny of the data absurdly difficult.

Contributors, for example, routinely employ different forms of their names and combinations of initials for different donations. They often list different addresses and depending on their situations - inconsistently report occupations and employers. Business executives who chair giant corporations, for example, will sometimes cheekily list their occupations as "retired" or assign any of several firms they have relationships with as their employer of record. On occasion active bankers report working in units long ago gobbled up by some other giant. Corporations employ a raft of similar (mostly legal) dodges, especially with subsidiaries. And that is before one gets to the now famous category of "dark money," where the true source of the financing is shrouded by streaming the lucre through faux "charities" that are not required to disclose donors.

We have developed complex statistical routines to pierce most of these veils and identify contributors, including assigning them appropriate industry codes. We discuss these methods in more detail in (Ferguson et al., 2013) and (Ferguson et al., 2016). ${ }^{41}$

Proceeding in this way yields many insights that are simply not available if one looks only at voting patterns. The results make is easy to specify precisely what is distinctive about the 2016 election. We can also explain very simply what brought about the dramatic changes that we identify and provide real answers to the three questions about the course of the election posed above.

We consider each of these issues one after the other. We tackle first the question of what made 2016 so extraordinary, then explain the factors driving the change, before presenting our answers to the three sets of questions posed earlier.

\section{What Changed}

Tables 2 and 3 display some statistics that show directly what was so remarkable about the 2016 election. They testify to the entry of dramatic new forces into the political system - eruptions of a kind that are extremely rare in American history. 
The first compares small donations (less than \$200 in total from donors, the threshold for FEC reporting) for the Democratic and Republican presidential candidates in 2016. For comparison, Table 3 displays comparable figures for 2012 major party candidates. The totals are of real interest in their own right, but the relative proportions large and small contributors are what is telling. 2016 almost perfectly inverts the pattern of the earlier election. In 2016, Donald Trump attracted a higher percentage of small contributions than President Obama did in 2012.

Tables 2 and 3 About Here

Fully comparable data for earlier elections does not exist, in part because price changes have gradually lowered the value of contributions below the legal threshold, which hasn't changed since 1979 (thus rendering more recent donations truly "small") and also due to drastic regulatory changes earlier in the seventies. We thus have to be cautious. But we believe that the 2012 pattern is representative of essentially all presidential elections since the New Deal, with the possible exception of 1964, when so many big businesses and wealthy Americans deserted Barry Goldwater, the Republican nominee, for President Lyndon Johnson (Ferguson and Rogers, 1986). Normally in general elections, the Democratic candidate attracted more small money. Trump shattered this pattern, which we regard as the equivalent of forcing water suddenly to flow up hill. Failed Republican primary candidates, especially Evangelicals, have often attracted relatively high percentages of small funds, but that reflects their inability to secure larger donations - compare the discussion of 2012 in (Ferguson et al., 2013). The striking novelty here is the massive weight of small contributions in a campaign that brought in really large amounts of money.

With respect to the Sanders campaign, these tables show something we are confident is without precedent in American politics not just since the New Deal, but across virtually the whole of American history, waiving the dubious case of the legendary 1896 election: a major presidential candidate waging a strong, highly competitive campaign whose support from big business is essentially zero. ${ }^{42} \mathrm{We}$ are hardly the first to notice this fact, but like many other others, we had trouble believing our eyes. Thus we checked carefully. Sanders stands out not only for the high percentage of small contributions, but the minuscule totals of large contributions in the aggregate. Later in this essay, when we consider the sectoral breakdown of contributions, we will see that the handful of small donations scattered among our counts of big business contributions to Sanders clearly derive from many lower level employees, not top management. The few large contributions arise from aggregated contributions from a handful of unions (the official union leadership of most unions supported Hillary Clinton, see below). In 2016, Bernie Sanders was sui generis - not at all comparable to Ron Paul, whose 2012 
campaign was hoisted aloft in part by a Super PAC funded by Peter Thiel and other mega-donors (Ferguson et al., 2013). He was exactly what he appeared to be, something truly new under the American sun.

The similarity in the voting patterns of 2012 and 2016, then, is deceiving. Behind the similarities lurk dramatic changes in patterns of political investment, testifying to the mobilization of powerful new forces into the political arena. The obvious next question is why they occurred in 2016.

\section{Misery in a Dual Economy}

To the question why such big changes in 2015 , our answer is straightforward: The mass movements that formed behind Trump and Sanders are consequences of the development of a dual economy in America.

The theory of a dual economy is best regarded not as a fully elaborated set of propositions, but as an evolving set of facts that various researchers have uncovered in the course of ongoing research. At the start, a word of warning: The scholars working in

this area depart from different standpoints and use various methods, so their treatments of certain issues can differ sharply. Several whose work is clearly relevant, do not use the term "dual economy" at all. But they spotlight a set of facts that is crucial to understanding how American politics passed into the Twilight Zone. Here our intent is not to exhaustively survey the whole body of work, but to outline what matters most for understanding 2016.

Peter Temin crystallized the discussion (Temin, 2015) (Temin, 2016). His starting point was the now well-documented extreme polarization of income and wealth over the last generation in the US and many other developed countries, even while real earnings for most workers stagnated. Temin looked beyond distribution to consider the evolution of the structures of industry and work that generate the disparities. He adapted a famous model developed by W. Arthur Lewis for the analysis of countries in what was then known as the Third World and applied it to the contemporary United States. He treated the US economy as consisting of two sectors. The first, the "primary" or "core" sector, embraces about "thirty percent of the population" (Temin, 2015) (Temin, 2016). It is dominated by finance, technology, and electronics (FTE, in Temin's shorthand) and "consists of skilled workers and managers who have college degrees and command good and even very high salaries in our technological economy." The sector includes, in other words, the very rich and rapidly shrinking middle classes.

The other "secondary" or "peripheral" sector he saw as populated by "low-skilled workers who are suffering the ills of globalization in its various aspects." He often refers to this other part of the economy as the "low-wage sector," and highlights the role of politics and technology in reducing the demand for semi-skilled workers (Temin, 2015).

Temin treats education as a source of both human capital in a Neoclassical sense, but also (along with families and neighborhoods) "social" capital. He views education as the passport that allows its holder to transit from one sector to the other. 
Refreshingly, Temin flatly rejects median voter models of the political system and accepts the investment approach to analyzing politics. He notes that primary sector workers, especially the very richest Americans whose income has grown the most, now champion low taxes. The resulting dismantling of public education and attack on the welfare state relies heavily on racial politics for political cover. The result is that chances are vanishing for most Americans of any race to enjoy a middle class standard of living.

Servaas Storm arrives at broadly similar views by a different path. He examines how bad macroeconomic policy - the unwillingness in the 1980s and after to pursue Keynesian policies of full employment - paved the way for the tendency for dual economies to develop not just in the US, but plant roots in economies all over the developed world. Storm is highly critical of mainstream macroeconomists for failing to recognize that their measures of potential output (used to define "full" employment) fail to reflect the true extent of the shortfall in aggregate demand because they simply track actual output with lags. Lower demand reduces income, which soon leads to lower estimates of potential output (Storm, 2017). ${ }^{43}$

Prolonged demand weakness, Storm argues, is more than many enterprises can resist. It tempts them to rely on low wage labor. This depresses measured productivity in many sectors in which it formerly grew, consigning productivity increases to a handful of industry branches in which rapid technological change dominates. Storm traces how over time many workers are steadily pushed out of the primary sector into the low wage sector. The stream of workers into the low wage sector accelerates the fall in sectoral productivity: Turnover is too high for many workers to sensibly invest in firm-specific skills and if there is any incentive for them to learn anything, it is mostly general skills that will make them attractive to the next employer, whom they can be sure they will soon be encountering.

Like Temin, Storm does not see the flow of workers out of the primary into the low wage sector as arising from a single factor. The flow varies by context, driven alternately by foreign trade, technological change, immigration, foreign direct investment, labor market regulation, and attacks on trade unions, as well as the business cycle.

Two other analysts do not couch their analyses explicitly in terms of a dual economy, but describe economic processes that are plainly integral to its workings. William Lazonick has shown how the rise of start up firms like Cisco and Microsoft propelled sweeping changes in the structure of American business. These boisterous infants of the "New Economy" faced the problem of attracting personnel with the right mix of technical knowledge and skills. Managers and technical workers in older firms could reasonably look forward to rewarding careers inside one firm. To encourage workers to move, the New Economy firms offered stock options on a vast scale (Lazonick, 2009) (Lazonick, 2017) (Lazonick, 2016).

For New Economy firms the stock market was vital, both as a way for venture capital to exit and take profits and as a way to confer value on the stock options, not as a source of initial funding. But the spectacle of financiers and managers becoming megarich almost overnight turned heads in the rest of the corporate economy. With Drexel 
Burnham Lambert promoting leveraged buyouts via the junk bond revolution and thus upending Wall Street's traditional relations with industry, top managements of older firms found the new ideology of shareholder value irresistible. They piled on stock options for themselves and dismantled older career ladders that provided scaffolding for long term commitments to the firm by workers and managers. They cut back on R\&D and other overhead expenses that only made sense for firms intent on producing a new generation of innovative products and concentrated instead on getting their stock prices up. Firms increasingly used their internal funds to buy back their stock instead of making continuing investments in their products and processes. Stock buybacks were a crucial factor in the stupendous rise of top management compensation relative to average workers rewards. In certain crucial sectors such as pharmaceuticals and electronics, firms often sustain themselves by appropriating technologies and inventions developed in government supported laboratories (typically at nominal costs) and gobbling up smaller competitors (Lazonick, 2009) (Lazonick, 2016).

Older notions of a career spent mostly inside one firm become increasingly obsolescent for many other workers besides managers, technical personnel, and scientists. But not because they were all luxuriating in stock options. David Weil has demonstrated in painstaking detail that as top managers of large firms ladled out stock options to themselves, they also reorganized their production processes by contracting out more and more labor - a strategy that allowed them not only to reduce the wages and benefits of ordinary workers they retained, but remove themselves from legal responsibility for monitoring how their lower wage client firms treated their workers. This strategy of "fissuring" the workforce led to enormous reductions in the number of permanent workers in primary sector firms and swelled the number of jobs in the low wage sector. As Weil shows in an especially perceptive discussion, the process creates powerful incentives for low margin firms under pressure in the low wage sector to skirt laws on wages and hours, including the theft of employee wages. Large firms can then plead that any resulting legal problems are the responsibility of the contractors, not them, and point to economic theories that claim that wage theft cannot be a viable long term business model as proof they can't be pursuing such a strategy (Weil, 2017).

\section{Why Upheaval in 2016?}

This in broad outline is how the dual economy has developed over several decades in the United States. But if one accepts the reality of structural changes of this sort, then an obvious question requires an answer: How does a long term process suddenly come to figure so dramatically in the recent election?

Part of the answer is implicit in the earlier discussion of 2014: we do not believe that the upheavals of 2016 marked the first time the dual economy affected US elections. Though we cannot fully discuss the issue here, we are confident that a close study of recent elections would reveal traces of the dual economy's influence, sometimes in ways that are not so obvious as in 2014. But our basic answer is that the 2016 eruptions constitute a tipping point - a moment when the many pressures that had been squeezing voters for a long time cumulated to a point where, quite literally, daily existence for many 
had become close to unlivable. There is strong evidence that many citizens were searching desperately for ways out of what looked (and in fact are) dead-end situations. Many rebelled as they listened to commentators tell them that the US economy was really doing better than it had in many years and that they should be celebrating America's exit from the Great Recession. They were unmoved by the chorus of conventional politicians trying to sell old nostrums that by 2014 were plainly obsolete for them in their communities. Empty slogans no longer appealed, they just disgusted or enraged. When two politicians broke through the big money cartels that dominate both major parties, popular enthusiasm surged almost overnight to seismic levels, shocking elites in both parties and flummoxing the entire American establishment.

With the same caution as before - that we have room here only for sketches - let us briefly consider how the dual economy weighed down so many Americans, making them desperate for relief.

First, there is the obvious: the grinding reality of continuous, unyielding low pay over many years that Storm, Temin, and other analysts place at the center of their analyses. By 2016, this had been going on for a full generation. For workers in the low wage sector, chances of sustained improvements in well being were remote - roughly comparable to the odds of winning one of the lotteries that have spread like a flu virus through fiscally pressed states. This put many stresses placed on workers are impossible to inventory here. But we would single out the record over time of children living at or near poverty levels. This is almost beyond belief and characterized by especially grotesque racial and ethnic disparities. ${ }^{44}$

Assessing the discontent of different groups of workers is difficult, because few reliable behavioral statistical indicators exist. Strike levels, for example, have been low for decades. That, however, is likely a result of the costs of mounting strikes and the dismal prospects for success. In a world in which capital is far more mobile than workers, and where employers are routinely able to violate labor laws with impunity, corporate America is simply too strong. The fatal weakness of "exit, voice, and loyalty" models that they do not incorporate an explicit cost function - are visible here for all to behold (Hirschman, 1970). The same holds for measures of labor union strength. They have been in steady decline in the US and many other developed countries for many years. ${ }^{45} \mathrm{An}$ interesting indicator suggestive of a possible tipping point, however, may be the expressed interest in minimum wages. Agitation for minimum wage increases, of course, reflects not only bottom up dissatisfaction but specific support from various activist and elite philanthropic organizations along with policymaking circles concerned about social unrest. Still, it is striking that a Google Trends analysis for the US shows steadily rising interest in minimum wages. This is likely related to the waves of protest about inequality that have broken out worldwide since the Occupy movement exploded into the headlines in 2011, (with, like the minimum wage discussion, important early encouragement from more liberal policymakers and business groups (Ferguson, 2014b)).

In the U.S., however, indices pointing to literally unendurable situations have been flashing red for almost two decades. Recently, as some have exploded, they have finally attracted attention. The best known studies are those of Anne Case and Angus Deaton. Their basic argument is that "after decades of improvement, all-cause mortality 
rates among white Non-Hispanic men and women in middle age stopped falling in the US and began to rise." Although "mid-life mortality continued to fall in other rich countries, and in other racial and ethnic groups in the United States, white Non-Hispanic mortality rates for those aged 45-54 increased from 1998 to 2013". (Case and Deaton, 2017).

This rise in mortality, which contrasts so glaringly with patterns in other wealthy countries and inevitably brings to mind comparisons with the former Soviet Union, chiefly affects white workers and their spouses with low levels of education and wages. In their efforts to frame explanations, Case and Deaton caution that "we are still far from a smoking gun or a fully developed model." But they propose a "preliminary but plausible story" of how "cumulative disadvantage over life, in the labor market, in marriage and child outcomes, and in health, is triggered by progressively worsening labor market opportunities at the time of entry for whites with low levels of education" (Case and Deaton, 2017). Shannon Monnat and other researchers, including Case and Deaton in their recent work, have explored how experiences of persisting pain has contributed to the wave of opioid use roiling so many communities in recent years (Monnat and Brown, 2017).

Everyone studying these matters recognizes that no one sort of locale has a monopoly on these dismal conditions. They are found everywhere, if one looks, from large cities to rural hamlets. But Monnat and others have drawn attention to the role place plays in the process.

A growing literature in mainstream economics and urban studies celebrates the role cities and especially "world cities" are said to play in stimulating economic growth in the age of globalization (Glaeser, 2011). But the United States and many other countries are today dotted with ruins of once-great industrial or mining areas that have never recovered from hammerings they received from the flood of competing imports or the relocation of their production centers that also followed from economic globalization. For all the brave talk by mainstream economists, foundations, and politicians about "Pareto improvements," "comparative advantage," and the "income-augmenting" role of international trade, in many places economic activity has never recovered. (Autor et al., 2016). Older mining and industrial plants stretch like Halloween skeletons over desolate, slowly depopulating landscapes. Younger people leave for cities, as aging residents, with little prospects in the New Economy, struggle to get by on disability or Social Security, as they or their children often turn to opioids and other drugs.

In the US, the collapse of the housing bubble compounded these problems; home values in many of these communities left behind have not recovered, leaving individual home owners - those who still have their dwellings, that is - close to underwater or actually insolvent (Zonta et al., 2016). We note, grimly, that surveys that track only incomes miss much of the action that matters here, which concerns liabilities as much as assets. ${ }^{46}$ And we are not surprised that economically sensitive analysts who take the time to sort out effects by place find that big surges in imports, such as those that hit both Germany and the United States in the last generation, led to striking political changes (Autor et al., 2016) (Autor et al., 2017) (Dippel et al., 2015). We think it is inevitable that citizens living for long periods in immobile economic and social circumstances will increasingly find that large chunks of the "common sense" of other, more globally 
oriented parts of the country grate on them, and indeed, come to seem almost meaningless or downright perverse. The realities of life in the contrasting prosperous areas - which scatter across individual countries like islands in archipelagos, not giant territorial blocks, diverge too much. Behind all the talk of increasing demographic division in the US, in other words, we suspect are some real but less-mentioned divisions by place that provide the raw material with which demagogues and politically oriented commentaries go to work. The tendency toward growing isolation, (thanks to sheer facts of income imbalances and a rapidly differentiating media environment), plus some hard work and a lot of money can make it seem as though each side lives in a bubble, because they do.

But alas, the miserable incomes and precarious life conditions that dual economies generate for more and more citizens define only part of the problem. The thousand natural shocks that workers in the low wage sector are heir to are multiplied many times by the decay of educational opportunities and the welfare state.

Let us start with education, which, as Temin observes, is the royal road to the middle class, if hardly the $1 \%$. As he shows, the incessant drumbeat for lower taxes, which echoed in both (investor-driven) parties since the mid-1970s, led to drastic declines in funding for public education. Many state university systems today have withered away to an astonishing extent. Often state support provides a third or less of total revenues. Public K-12 education has been hammered in virtually all major cities and, increasingly, even in suburbs.

The collapse of state support closes off college to many low-income students. That is terrible and demoralizing in itself. But the mixed public and private US system has come up with a partial solution that is uniquely pathological: it struggles to make up the public shortfall by encouraging massive private borrowing (Cillufo, 2017). There is little doubt that investment in education has high social rates of return. The social rate of return on government grants and lending at low rates to students who can do the work should therefore be high (with one qualification noted below.) Instead, most Republicans and some Democrats - encouraged by handsome campaign contributions from private lenders - have done their best to bottle up governments at all levels from acting.(Swann, 2017) This forces many students to turn to private financiers, who often lend at double digit rates or higher, even after the 2008 crash when interest rates fell to historically low levels. The hideous practice of students trying desperately to mortgage streams of their future income to individual private lenders - a modern form of debt peonage - is now appearing, as trapped would be borrowers desperately seek escape from dead end jobs in the low wage sector.

The mountain of student debt that has built up now competes with credit card and auto debt and ranks respectably even against housing debt. ${ }^{47}$ Since the Great Recession, however, a more subtle and deadly effect has appeared. In part this arises from the austerity policies that nearly all major developed countries have pursued since the 2008 collapse. But a portion of it is a direct consequence of the growth of the dual economy that the mainstream literature has yet to spotlight: The primary sector cannot shrink consistently over time, without impacting the demand for professionals and trained personnel. A widening dual economy, that is, implies a slowly building crisis in the 
professions and managerial and technical training as students come out the other end of the education system and find the pool of available positions constrained.

This problem - which is separate from, but in practice compounded by, offshoring of middle class work made possible by improvements in telecommunications - shows up in many countries besides the United States. As so often, however, the incentives for individual institutions in the sprawling US system make everything worse: institutions, public and private, use every means at their disposal to herd paying students through. Many lower their standards and encourage students to borrow. The result, increasingly, is a race to the bottom, a macabre confirmation of convergence of developed economies with many developing countries that inspired the Lewis model: a proliferation of increasingly meaningless degrees whose holders emerge with heavy debts but only remote prospects for middle class positions.

The tendency to try to use private debt to plug holes in individual lives left by the retraction of a desperately squeezed public sector produces many other pathologies. One is particularly important: health care.

The basic problem of the U.S. medical care system - its fabulous costs and wretched outcomes relative to health care in most of the rest of the world (including all of the developed world) is well documented (Ferguson and Johnson, 2011). The Obama administration's Affordable Care Act brought some real improvements, but it did not solve the most basic problem facing average citizens: that serious medical problems capable of bankrupting them can strike almost anyone, anytime, even high up in the middle class. Too many issues with coverage and charges, especially so-called "balance billing," were left unresolved. The Affordable Care Act also did not go very far to actually make medical care affordable; large numbers of American are forced to go without food or medicines that they need, especially when they are sick, and the public demand for limits on the costs of medical care is strong (DiJulio et al., 2017). For political reasons, the Obama administration, the Clinton campaign, and a vast number of allied analysts sought to downplay the harsh realities during the 2016 election, but on one occasion in early October, Bill Clinton slipped off message. To the consternation of the campaign (which immediately muzzled him), he told the truth: "You've got this crazy system where all of a sudden 25 million more people have health care and then the people who are out there busting it, sometimes 60 hours a week, wind up with their premiums doubled and their coverage cut in half...It's the craziest thing in the world".(Allen and Parnes, 2017).

In the money-driven US political system, regulatory policy rarely helps ordinary Americans, as millions of homeowners bitterly discovered when the housing bubble burst. In the long run up to the financial crisis, major financial regulators like the Securities and Exchange Commission, the Commodity Futures Trading Commission, and the Federal Reserve - not to mention the Treasury - acted like textbook examples of industry-captured vehicles. Before the crash, only one state attorney general - Eliot Spitzer - ever mounted a challenge with real teeth, while isolated activist regulators, notably Brooksley Born, were rolled by the massive weight of industry political power (Epstein and Montecino, 2016) (Ferguson and Johnson, 2009a) (Ferguson and Johnson, 2009b). After the crash, no major financiers went to jail, while first the Republicans and 
then the Democrats bailed out Wall Street but not Main Street. Citibank and other institutions kept piling on leverage and thinning out their capital but then were rescued, while losses to pensions and housing values of ordinary Americans were never made good - as many Americans certainly still recalled in 2016. Monopolistic practices in telecommunications cost consumers hundreds of millions of dollars, with (at best) mild checks - no matter which party is in power, thanks in major share to the power of political money (Cooper, 2016) (Ferguson et al., 2017). No regulator does much to protect consumer privacy. Virtually the only thing one can trust about anti-trust policies is that authorities in charge are far more likely to have qualms about, say, cement companies than real giants whose charges for cable or wireless service come almost miraculously close to each other.

\section{Republican Orthodoxy is Disrupted}

As the presidential race began in earnest in 2015, the chances of any candidate seriously addressing the issues thrown up by the dual economy looked slim indeed. Most observers expected a rerun of a movie everyone had seen before: a battle between representatives of the two political dynasties that had dominated American public life for most of the period in which the dual economy took root: The Bush and Clinton families.

That prospect turned off an indefinite number of Republicans, especially conservatives. It also gave rise to a whispering campaign that occasionally broke into the open suggesting that Jeb Bush might really be a much weaker candidate than his predecessors and could be vulnerable. But at the outset the shape of the political coalition that seemed destined to dominate looked set. It was a twenty-first century version of the older Republican establishment bloc dominated by multinational finance, oil, and other globally oriented industries that had carried two earlier Bushes to victory (Ferguson and Rogers, 1986) (Ferguson, 2005). ${ }^{48}$ In such an alignment it was foreseeable - and actually did happen - that as the campaign started, Jeb Bush would unveil a gigantic war chest that was plainly designed to overawe both the media and any challengers who might be tempted to critically evaluate his proposals and past record.

The next step in the grand design would then be a series of debates as highly choreographed as a Japanese tea ceremony. Endorsements and accolades from party leaders would cascade down on the Anointed One, along with yet more money. According to a popular academic theory of nominations (one that we have never embraced, since it fails to recognize the critical role of political money, both direct and indirect) the resulting consensus of party leaders would make Bush's triumph inevitable. $^{49}$

As Bush and the doomed also-rans slogged through the primaries, it could be confidently forecast that the range of issues they would discuss would be astonishingly narrow. To many spectators the truncated range would sound eerie, as though everyone on stage in the debates was in the iron grip of some powerful force blocking normal human speech. This, of course, was because they were: The investment approach to party competition emphasizes the decisive role of political money in conditioning political 
appeals. No matter how many Americans want to preserve Social Security, pursue economic policies that target rising wages, or close off the possibility of personal bankruptcy due to medical expenses (to take three issues on which the direction of public opinion even in many Republican primaries is fairly clear) only appeals that can be financed have any prospect of making it into the political arena (Ferguson, 1995a).

From this standpoint, candidates' messages in the Republican Party were almost as predictable as eclipses. You just needed to put them in the context of their donor base(s). This major media sites that reveled in complex voting statistics somehow never managed to do.

In Bush's case, everyone knew what he stood for before he said it, indeed, even if he sometimes hesitated to say it, out of calculated discretion. He, like his father and brother, favored free trade, including the Trans-Pacific Partnership; multilateralism; the traditional structure of U.S. alliances; close relations with both Israel and Saudi Arabia; a huge worldwide military; and all the wars waged during the various Bush presidencies. He did not like Iran, but his criticisms of the nuclear accord negotiated by Obama were formal and not entirely credible. The best guess was that James A. Baker, who had served his father and rescued his brother in the Florida imbroglio, and other like-minded establishment types, would prevail when push came to shove. A Bush administration would find some way to live with the deal, which even Baker was on record as halfheartedly opposing.

On Ukraine, Syria, and other issues, Bush would be dependably anti-Russian without being hyper-shrill. Like the rest of his family, he believed close relations with China were vital to preserving world order, while also being completely committed to maintaining the American Seventh Fleet as a bedrock of the American alliances with Australia, Japan, and - very carefully - Taiwan. He opposed Obamacare and network neutrality, both red lines for Republicans, and claimed to be suspicious of climate change, though many in the GOP suspected he might be more flexible on the last. Virtually everyone realized that, like his brother George W., he really would like to trim Social Security and replace it with private investment schemes administered by Wall Street, but the logic of not making a big point of that in the campaign was apparent. Of course he could be relied upon to cut taxes yet again and further deregulate industry.

Those positions dovetailed with the mammoth business coalition that enlisted behind Bush. Table 4 breaks out the financing for all Republican primary candidates in terms of industries (including Trump up to May 4, when Ted Cruz, his last serious challenger, withdrew following a disastrous loss in the Indiana primary). ${ }^{50}$ The Bush bloc was anchored in multinational banking and finance, with strong representation - meaning hundreds of thousands of dollars raised - from all major banks, many private equity and hedge funds, insurance companies, and other financial houses. ${ }^{51}$ But the coalition also embraced many sectors with historical ties to the Bush family, including oil and chemical companies of all sizes, along with firms and investors in coal, mining, paper, and other sectors that have traditionally battled regulations designed to limit the dangers of climate change (Ferguson et al., 2013). Big firms in telecommunications, notably the descendants of the old Bell operating companies and major cable firms providing access to consumers that strongly oppose network neutrality (since they run the networks that the measure 
would crimp) were also heavily represented. ${ }^{52}$ Transportation, Big Pharma, and the entire private health care industry, including insurers, were also abundantly present. It looked like the Golden Horde was reincarnating, just like in the old days - almost.

Table 4 About Here

A business base of such dimensions of course complicated all mass appeals. Many measures the coalition supported, such as the trade deals, were very unpopular. The Party also represented employers first and foremost; neither in its higher nor its lower circles was there any space whatever for unions or, typically, even minimum wages, a measure intensely disliked by most smaller firms in the low-wage sector. The question of how the Republicans could appeal to blue- or grey-collar workers was thus highly fraught. The party had been grappling with this problem for more than a generation, especially since its discovery in the Goldwater campaign of 1964 that free markets roused little mass enthusiasm, but appeals on crime and moral decay did resonate (Phillips-Fein, 2009) (Ferguson, 1995a) (Ferguson and Rogers, 1986)

By 2015, the laboriously erected scaffolding that connected the Republican establishment with the specialized segments of the wider public that the party had any chance of attracting on these grounds had grown thin indeed. As a former governor of Florida, married to the Mexican-American daughter of a migrant worker, Bush was adept at picking his way along that tricky path. He was opposed to abortion, though not aggressively promoting still more restrictive legislation. True believers suspected he would, like his father and brother, sell them out once in power. The former governor professed to consider hunting sacrosanct and opposed gun control. Where he stepped most tentatively and carefully was on immigration. He radiated confidence that immigration was a good thing and indicated that he might be open to some kind of grand bargain on immigrants and "Dreamers," (the children of illegal immigrants born in the United States, who in many cases knew no other country) though this came steel-encased in rhetoric about border security.

The strategies of the other contenders for the nomination - all but one -- are also easy to understand in light of Table 4 . They faced the challenge of attracting enormous sums of money from a potential donor base that heavily overlapped Bush's. As Table 2 showed, save for the candidates appealing directly to evangelicals - Carson, Huckabee, and (with some major qualifications) Cruz and Fiorina - and the special case of Rand Paul, all the candidates depended heavily on contributions of a thousand dollars or more. The plain fact, however, was that appealing only to small donors in a Republican primary was akin to trying to paddle a canoe in the face of an oncoming tidal wave. Many candidates, unsurprisingly, appear to have made virtually no appeal to small donors. They floated mainly on contributions above $\$ 10,000$, as Table 4 indicates. But no matter where candidates beat the bushes for money, this was a Republican primary. No one who hoped 
to attract big business support could reasonably expect to succeed who did not walk in lockstep with most of the cardinal tenets of the Bush campaign: free trade, multilateralism, vast spending on defense, endless wars, etc.

In all likelihood, a substantial number of the minor candidates who threw their hats into the ring, including Huckabee, Gilmore, Pataki, and Jindal really aspired to cabinet positions or slots on the Fox Network. Christie, Fiorina, and Rubio were likely running for Vice President. They and any others who entertained hope that lightening would strike if Bush stumbled could be sure that their chances would not be enhanced by bolting from Republican orthodoxy, especially on the urgency of cutting taxes.

The likely also-rans thus pursued strategies that strikingly resembled canonical models of imperfect competition in microeconomics. They first hit up such patrons as they had developed and interests they knew from their days in power. Though we lack the space to detail individual cases, such contributions figure among the large donations to most of the various campaigns. It is tempting to describe these top-heavy patterns as industrial versions of the "friends and neighbors" voting much studied by electoral analysts. Fiorina's case is particularly clear cut, as she had headed up a major telecommunications company, but several of the governors also provided obvious examples. From their various bases, each candidate then experimented with offering slightly differentiated versions of essentially the same product as Bush, adding bells and whistles that might appeal to different audiences of investors and different segments of the likely Republican electorate. Then they hoped for the best.

All the contenders, for example, claimed they were pro-life, including several who had to clumsily walk back past positions that were less intransigent. Many candidates added wrinkles to the basic "no": they staked out more extreme positions on modifying existing laws to make abortions even harder to obtain or to throw still more roadblocks in the way of Planned Parenthood. Carly Fiorina directly promoted overturning Roe vs. Wade; others pushed limiting abortions after 20 weeks, etc. Almost everyone professed to doubt that human activity affected climate change, though Fiorina at times made noises that humans might actually affect the climate but that governments could not do anything about it. No one apart from Bush made many friendly gestures to Muslims. Neither did anyone speak up for network neutrality, which would have been anathema to the telcos.

Marco Rubio and Carly Fiorina both aspired to the multinational mainstream on economics - Fiorina had run Hewlett Packard - but they competed to see who could be more convincingly bellicose toward Iran and Russia. The ranks of their donors reflected these moves, along with their local economic bases. Rubio resembled a rightward tilting Bush and garnered wide support from various multinational banks and industrial firms. But his vehement pose on Iran drew proportionately heavier applause from outspoken critics of establishment foreign policy, such as the financier Paul Singer (who had for some years helped subsidize an alternative foreign policy forum), prominent defense contractors, some oil companies, Neoconservative critics of Obama's policies in eastern Europe and the Middle East, and American champions of the Likkud Party's interpretation of Israeli interests. Fiorina, along with Scott Walker (the Governor of Wisconsin) proposed arming Ukrainians resisting the Russian supported separatists with 
advanced weapons. She also cheered the idea of increasing the number of American troops in Europe.

Other candidates pursued different niches. Ted Cruz's main appeal was as defender of Libertarianism who detested government and taxes and strongly promoted free trade, but whose father had converted from Roman Catholicism to become an evangelical preacher. He experimented with some low key criticisms of China, which was just then emerging as a larger problem for US firms operating there and for Silicon Valley enterprises increasingly alarmed by what might be termed the "supply side mercantilism" that the Chinese government practices in favor of its indigenous industries in high tech and other advanced sectors. A graduate of Princeton and Harvard Law, whose wife worked for Goldman Sachs, Cruz also garnered some contributions from Wall Street and from oil companies in and around his own state of Texas.

Chris Christie, Governor of New Jersey, received over a quarter of a million dollars from executives of Public Service Electric and Gas, the giant utility that that sells in much of his state. Then he struck off boldly ("courageously" as many newspaper accounts styled it) in a different direction. He promised to trim Social Security and cut "entitlements" as legions of tax-averse investors in both political parties have incessantly demanded. This brought him substantial contributions from Wall Street hedge fund managers and investors, accounting executives, and a fairly broad cross-section of mostly eastern-centered large firms, including some who were outspoken proponents of cutting entitlements. His was a campaign that relied especially heavily on truly large contributions.

So it was that in the very earliest days of the race, the script appeared to be holding up. Money rained down on Bush. The rest of the field gasped for air (money) and plugged away to differentiate themselves enough to reach the minimum poll levels they knew sponsors of the Republican debates would require.

On June 16, 2015, something took place that was not in the script. A member of the Forbes 400, whose reality TV show had made him a household name to millions of Americans, announced that he was joining the race. Unlike the other candidates, he did not have to think a long time to find a suitably impressive location to kick off his campaign. He simply walked down a staircase in the high tower in New York City that bore his name and met the press.

That Donald Trump might jump into the race had been rumored for a while; it was an open secret that he had toyed with the idea several times before. For more than four years, he had been fanning suspicions about where President Obama was really born and whether he was a closet Muslim. But the political establishment had always scorned Trump, and refused to take him seriously this time, either. The idea that he would run for president excited more laughter than anything else (Green, 2017) (Blair, 2015) (Kranish and Fisher, 2016).

But the apparently off-the-cuff remarks that he made at that announcement resounded like thunder across the United States and in Mexico: "When Mexico sends its people, they're not sending their best. They're not sending you. They're not sending you. 
They're sending people that have lots of problems, and they're bringing those problems with us. They're bringing drugs. They're bringing crime. They're rapists. And some, I assume, are good people" (Staff, 2016). On the heels of his announcement Trump gave an exclusive interview to a Breitbart News reporter, so that the vast network built up by Steve Bannon and the Mercers could not miss the message.

His promise to build a wall along the border horrified Republican elites, who after the 2012 election had sought to repair the Party's relations with Latinos. It also appalled millions of Americans who considered it out-and-out racism. But after Trump flew to Laredo, Texas, in July, ostensibly in response to an invitation from a local of the Border Patrol union and promised both a Wall and jobs as part of his program to "Make America Great Again," he shot up in the polls. ${ }^{53}$

Republican primary voters are anything but random samples of the American electorate. They are considerably older, richer, whiter, and far more conservative than the general electorate (Ferguson and Page, 2017). Trump's presence rather clearly spurred turnouts, but they remained very small in absolute size - about $17 \%$ of the total potential electorate in both parties (Desilver, 2016). In a field with more than a dozen candidates, Trump's usual, but not invariable, pole position for much of the race was an enormous strategic advantage. It meant that Bush and the rest of the field had to battle each other to stay in the debates while trying to keep up with him.

Later, as the dazed Republican establishment licked its wounds and sought to come to terms with what was happening to it, the legend grew up that Trump's triumph really showed that money didn't really matter in politics. Trump won, the argument went, because of all the free publicity the mass media afforded him. We have more to say about that subject below, when we analyze the crises that threatened Trump's campaign in the late summer of 2016. But for now there is a simple response. Yes, Donald Trump was well-known from his television show. But what gave him the freedom to jump into the race and trash-talk the other candidates into oblivion was the fact that he was a billionaire. He didn't need the money of the Bush Golden Horde or the many 1-percent fans of Marco Rubio, Scott Walker, and the rest. Or the Kochs. Or the defense and aerospace industry.

In a normal election year, anyone who talked like Trump in the GOP primaries might hope to shuttle around some early small states and make a brief splash, before being swamped by a wall of money in big multi-state primaries on some Super Tuesday later in the campaign.

Not Trump - he was never going to run out of money in the primary as long as he was willing to open his own wallet, and everyone knew it. His money gave him both the means and the confidence to break the donors' cartel that until then had eliminated all GOP candidates who didn't begin by saluting the Bush family for starting the Iraq War, incessantly demanding cuts in Social Security and Medicare, and managing the economy into total collapse via financial deregulation. He could even mock the carried-interest tax loophole and sneer at Wall Street. He could say whatever he wanted as he flashed around in his own private jet with an almost presidential entourage of guards, schedulers, and advisers that other campaigns had to pay dearly for. He could make charitable 
contributions to veterans' organizations and other groups whose timely support could be helpful and which would not show up in any campaign finance tabulation. And anyone who did a favor for his campaign could be confident they were helping someone who would be around for a long time, no matter how the campaign turned out - indeed someone who seemed intent on setting up some kind of a network or mass movement if somehow he didn't win (Barajas, 2016).

The effect of Trump's freedom to talk, along with the apparent credibility his membership on the Forbes list conferred on him when he talked about jobs and foreign trade, and his attacks on immigrants, highly publicized quarrels with women political commentators, and demands for "America First" in foreign policy was electrifying - like throwing open a tomb that had been sealed for ages. Next to the struggling wraiths who toiled in the Republican primary, he looked like Shakespeare's Julius Caesar, who "doth bestride the narrow world like a colossus." The political establishment couldn't comprehend what was happening, or why even people suspicious of him couldn't take their eyes off him. Trump just laughed at the other candidates' shibboleths and their stuttering incapacity to say anything to any real person or address the issues pressing so hard on Americans living in a dual economy.

In analyzing the Trump vote, the published exit polls conducted by media consortia are only modestly helpful. Their displays include only a few controls. The American National Election Survey data can be much more useful, if carefully done. Because of the importance of the spatial inequalities that the dual economy produces, for example, we suspect that normal controls for income are less useful than in the past. The key issue is likely long-term stagnation in places where respondents live, which year-toyear measures will not catch. One should be cautious, therefore, in pointing to voting data from the 2016 election. Still it is striking that in the Republican primaries, early analyses suggest that Trump ran especially well in counties with heavy concentrations of poor whites who had relatively low levels of education - exactly what one would expect from the earlier analysis of the dual economy (Guo, 2016). The pull of the promise of "making America great again" was intense: Even in Iowa, where Trump narrowly lost, evangelicals, presumably one of the last groups one would expect to be attracted to a loose-talking and loose-living figure like Trump, deserted their pastors in substantial numbers. As the Republican campaign wore on, the flow turned into a torrent, leaving Ted Cruz, Ben Carson, and other candidates who courted the evangelicals out in right field.

\section{The Democratic Earthquake}

On the Democratic side, just like the Republicans,' a consensus script existed for the primaries. The Democratic counterpart to Jeb Bush was Hillary Clinton, who was supposed to cruise more or less effortlessly to the nomination. As a lawyer with a distinguished career in her own right, a very involved First Lady, U.S. Senator, and then Secretary of State under President Obama, she could hardly be faulted for lack of experience or credentials. The prospect of becoming the first woman President lent her 
candidacy an extra layer of dignity and importance, though, obviously, it also stimulated various attacks that in many cases were less than good-willed or even in good faith.

Not everyone, however, was entranced by all parts of her record. It was no secret that Hillary had played an active-behind-the scenes role in her husband's presidency. Bill Clinton's enthusiasm for financial deregulation was well known; it was during his presidency that milestone deregulatory legislation had been enacted, such as the final abolition of the Glass-Steagall Act that used to separate investment banking from commercial banking. Many of the biggest battles in the long fight by the banks to keep derivatives from being regulated had also taken place during his administration, with Robert Rubin, Lawrence Summers, and other key Clinton appointees (together with some Republicans like Phil and Wendy Gramm) driving that policy as both Clintons looked on benignly.

Hillary Clinton's record as Senator from New York in regard to financial deregulation was consistent with this arc. Before the collapse in 2008, she lagged far behind many other Democrats in efforts to restrain Wall Street (Linskey, 2016). After staunchly supporting the key free trade initiatives of her husband, including the landmark North American Free Trade Agreement (NAFTA), she hewed to the same line in the Senate. Records disclosed during the 2016 campaign showed that as Secretary of State Clinton enthusiastically supported the Trans-Pacific Partnership that the Obama administration hoped to push across. Only after leaving office did she finally come out against the TPP during the campaign (Allen and Parnes, 2017).

As Secretary of State Clinton had worked closely with many big American firms, especially Google, which promoted a global vision of countries linked by worldwide telecommunications markets dominated by lightly regulated giants like themselves (Assange, 2014). In Asia, this support for free trade came accompanied by a hawkish stance toward China. It was during her tenure as Secretary of State that one of her subordinates discovered that the US mutual defense treaty with Japan covered an island that the US officially was not sure even belonged to Japan.

Like Bill Clinton in the nineties, Hillary Clinton also strongly promoted NATO expansion. In 2008, as a Senator, she had cosponsored a resolution to bring both Georgia and Ukraine into NATO, which was guaranteed to produce in Russia roughly the same sensation as a Russian pact with Canada would in the US (Sachs, 2016). She continued down this path as Secretary of State. Her Assistant Secretary of State for European and Eurasian Affairs, Victoria Nuland, played a key role in the US effort to squeeze Ukraine into choosing between Europe and Russia (to paraphrase the rueful description by the then German Vice Chancellor, after the plan miscarried) (De Ploeg, 2017) (Behrakis, 2014). Clinton also pushed to challenge the Russian backed regime in Syria and strongly promoted changes in Egypt and other Arab regimes, including, most fatefully, Libya. As discussed below, a Clinton tilt toward the Neoconservatives became more pronounced as she left the administration to prepare for her presidential campaign.

Years of fending off vitriolic conservative attacks had left the Clintons wary; they certainly appreciated the value of institutional resources, including money. But many observers, including (as an email disclosed by WikiLeaks revealed) Colin Powell, and 
some top officials of Hillary Clinton's own campaign, had qualms about the lengths the Clintons were prepared to go to build a war chest (Geller, 2016). The Clinton Foundation's pursuit of donations from regimes in central Asia and the Persian Gulf that were anything but models of democracy attracted attention, especially when clumsy efforts to conceal them through screens were exposed. The Washington Post reported that between 2001 and 2013, the Clinton Foundation had raised almost \$2 billion dollars from "a vast global network that includes corporate titans, political donors, foreign governments and other wealthy interests" (Helderman et al., 2015). Eventually the Foundation and its financing became the target of a book commissioned by Steven Bannon in advance of the 2016 election (Schweitzer, 2015). The Foundation, however, hardly exhausted the Clinton's efforts to shake the money tree. CNN reported that between February 2001 and May 2015, (when Hillary Clinton declared for the presidency) the Clintons had received more than $\$ 153$ million in speaking fees. Almost eight million dollars of that came from just a handful of giant banks, including Goldman Sachs, UBS, Bank of America, Citigroup, and Deutsche Bank (Yoon, 2016).

When queried about all this largesse, Clinton's answers were often less than reassuring. In the campaign she flatly refused to make public the text of speeches she made for Goldman Sachs after leaving the Department of State, which was widely interpreted as a strong signal to the financial community. At times she challenged questioners to name a vote she had switched for money, implicitly dodging questions about her long support for policies that 2008 had clearly shown to be disastrous. Asked after the campaign had ended why she kept chasing so much money, she dismissed the question by responding that the companies paid such fees to men all the time (Marcus, 2017). In the meantime, money poured into her campaign not only from Wall Street, but from a broad cross-section of American big business, as Table 5 shows.

Table 5 About Here

Neither Martin O'Malley nor James Webb, two hopefuls who also entered the race, posed any challenge to Clinton in regard to fundraising or anything else. Like the Republican also-rans, each started from a small base of big donors that they then could not expand, though Webb - a vaguely populist defense hawk - also attracted some small donations. Both quickly dropped out.

In the face of Bernie Sanders' onslaught, however, Clinton's responses to questions about her relations to Wall Street looked lame in indeed. Written off as quixotic when he announced, Sanders's meteoric rise stunned everyone. The avowed Socialist from Vermont did not rely on the usual coterie of Democratic insiders on corporate and foundation retainers for advice on policy and the economy. In sharp contrast to the 
Clintons, Sanders had long supported labor unions, not simply by talking with (some of) their leaders, but actually showing up on picket lines to support campaigns to organize workers. Unlike Clinton, who claimed that she went to Iowa to "listen" to voters and excelled in spelling out the wonkish details of particular programs, Sanders forthrightly addressed the central problems that the dual economy creates for ordinary Americans. Unionization was part of his answer to low pay. Increasing aggregate demand by taking aggressive action to guarantee full employment and fund major public projects was another. In front of millions of people who probably had never heard anyone press such issues before, Sanders argued for implementing single-payer health care and getting big money out of politics. He also tackled the college debt problem head on, saying that the first two years of college should be free and proposed a plan to forgive student debt.

The response was overwhelming. A genuine mass movement, the Sanders campaign followed a wild grass-roots logic of its own that the central staff had no hope of fully controlling. The surge unnerved not only the Clinton camp, but the entire American establishment. Major media outlets that happily afforded Trump waves of free coverage were far more grudging toward Sanders. Many stories in the Washington Post and other media did not even attempt to be even-handed, though in the latter stages of the campaign his press coverage improved. ${ }^{54}$ But it didn't seem to matter. When Sanders responded to Clinton in a debate that no one on Wall Street ever offered him six-figure fees for speeches one could almost hear the TV audience collectively suck in its breath. Likewise when he reminded Clinton of her husband's role in the financial deregulation that destroyed the world economy and reproached Clinton, who claimed to be the experienced foreign-policy hand, for simply swimming with the tide in the run-up to the invasion of Iraq. While Clinton claimed Henry Kissinger as a mentor and praised his foreign policy acumen, Sanders bluntly declared that he was proud to say that Kissinger was not his friend and that he would not take advice from him (Harris, 2016).

Sanders clearly connected with the concerns of many listeners, especially with young people. To many in the generations who had grown to maturity after the Cold War, Sanders' proposals sounded like common sense, not pie in the sky. They and millions of their elders appreciated his proposals on student debt and his forthright discussion of economic inequality, health care, Wall Street, and labor markets. And he waged his campaign on a broadly inclusive basis, stigmatizing bankers, not racial, religious, or sexual minorities. Most astonishing of all, though, was how Sanders financed his effort. This was the real secret of his "revolution": Money just kept pouring in from small contributors. We have checked carefully to see if Sanders, like Obama in both 2008 and 2012, perhaps received large sums delivered in small doses from big donors (Ferguson et al., 2013). He did not. The entries for big business in Table 5 come from scattered small contributions from firms where large numbers of individuals contributed. There were essentially no big ticket contributions from top executives and, a fortiori, no Super PACs. (Younger workers, who in some cases were quite vocal about the absurdly skewed pay levels in their industry, show up especially heavily in Silicon Valley and other high tech locales.) The handful of relatively large contributions arose from summed donations of a few unions (most unions, if much less clearly union members, supported Clinton). ${ }^{55}$ 
The Clinton campaign had always believed that her long time ties to the Black community would tide her through any rough patches (Allen and Parnes, 2017). Although by the end of the race young African Americans were coming over to Sanders in substantial numbers, that calculation was basically right. Sanders kicked off his campaign for the presidency in the aftermath of the protests in Baltimore over the death of a young black male in police custody. Had he gone there to make the announcement, as some younger members of the campaign staff favored, perhaps things might have been different. But he took the advice of his more experienced advisers and did not. In the end, Sanders won millions of votes, including a shocking upset in the Michigan primary, and swept through many western state caucuses like a prairie fire. But the Clinton campaign's care and feeding of the Democratic Party Super-delegates, her control of the Democratic Party machinery, and the enormous advantages she started with proved just enough to secure her victory.

\section{Big Money and the Triumph of Trump}

On May 3, Trump won the Indiana primary. Senator Ted Cruz, one of his last two remaining opponents, dropped out of the race. The next day Ohio Governor John Kasich, whose campaign had won some support from portions of Wall Street (including some investors who had also supported Chris Christie) suspended his campaign. Trump's nomination now appeared inevitable. Nevertheless, speculation and rumors about schemes to prevent his nomination by members of the Republican establishment ran rife in the media.

Well before then Trump had started enlarging his campaign entourage. In March, he had brought in Paul Manafort to bring order to the campaign's pursuit of convention delegates (Sherman, 2016). A veteran Republican operative who had helped coordinate Ronald Reagan's 1980 southern campaign strategy before becoming a lobbyist and adviser to a string of authoritarian leaders in the Philippines, Zaire, Angola, Somalia, and (as all the world now knows) Ukraine, Manafort began by trying to tone down some of Trump's campaign rhetoric (Sturgis, 2017). As pressure intensified to conciliate as many Republicans as possible in order to rivet down the nomination and secure support in the general election, Manafort's role widened. By mid-June, amid brutal infighting, he took over leadership of the campaign (Green, 2017).

As our Table 4 above showed, Trump had largely financed his primary campaign with small contributions and loans from himself. As late as mid-May, he remained convinced that his success in using free media and his practice of going over the head of the establishment press directly to voters via Twitter would make it unnecessary for him to raise the " $\$ 1$ billion to $\$ 2$ billion that modern presidential campaigns were thought to require" (Green, 2017).

As the convention approached, however, the reality of the crucial role of major investments in political parties started to sink in. Some of the pressure came from the Republican National Committee and related party committees. Their leaders intuitively grasped the point we demonstrated in a recent paper: that outcomes of most congressional 
election races in every year for which we have the requisite data are direct ("linear") functions of money (Ferguson et al., 2016). The officials could safely project that the pattern would hold once again in the 2016 Congressional elections (as it did - see Figure 3). ${ }^{56}$ But the Trump campaign, too, began to hold out the tin cup on its own behalf with increasing vehemence. As we noted earlier, small donations had been flowing steadily into its coffers. Unlike most previous Republican efforts, these added up to some serious money. But in the summer it became plain that the sums arriving were not nearly enough. In many senses, Trump was no Bernie Sanders.

We have combined federal records from different sources to create a day-by-day picture of the Trump campaign's incoming cash flow (including "outside money" supposedly uncoordinated with the campaign - see Figure 4). We are able to source the revenues to individual big businesses and investors and aggregate them by sector (Table 6) and also by specific time intervals. Our data reveal aspects of the campaign's trajectory that have received almost no attention. It is apparent that Trump's and Manafort's efforts to conciliate the Republican establishment initially met with some real success. The run up to the Convention brought in substantial new money, including, for the first time, significant contributions from big business. Mining, especially coal mining; Big Pharma (which was certainly worried by tough talk from the Democrats, including Hillary Clinton, about regulating drug prices); tobacco, chemical companies, and oil (including substantial sums from executives at Chevron, Exxon, and many medium sized firms); and telecommunications (notably AT\&T, which had a major merge merger pending) all weighed in. ${ }^{57}$

Money from executives at the big banks also began streaming in, including Bank of America, J. P. Morgan Chase, Morgan Stanley, and Wells Fargo. Parts of Silicon Valley also started coming in from the cold. Contrary to many post-election press accounts, in the end contributions from major Silicon Valley firms or their executives would rank among Trump's bigger sources of funds, though as a group in the aggregate Silicon Valley tilted heavily in favor of Clinton. Just ahead of the Republican convention, for example, at a moment when such donations were hotly debated, Facebook contributed $\$ 900,000$ to the Cleveland Host Committee. In a harbinger of things to come, additional money came from firms and industries that appear to have been attracted by Trump's talk of tariffs, including steel and companies making machinery of various types (Table 6). ${ }^{58}$ The Trump campaign also appears to have struck some kind of arrangement with the Sinclair Broadcast Group, which owns more local TV stations than any other media concern in the country, for special access "in exchange for broadcasting Trump interviews without commentary (Anne, 2017)."

Figure 4 and Table 6 About Here 
But our data and various press accounts also indicate that some important developments widely reported in the media took some time to mature. Many campaign accounts suggest that when Ted Cruz folded, the Mercers, Steve Bannon, and Kellyanne Conway went over to Trump, with whom Bannon had been intermittently working for a long time. This is just close enough to the truth to be potentially misleading. At the time, the Mercers were running an anti-Hillary Clinton Super Pac that had extended support to Ted Cruz, and Rebekah was having friendly discussions with the campaign and especially with the Trump family (Kushner and Ivanka Trump) (Gold, 2016). Robert Mercer made a large contribution to the anti-Hillary Super Pac, but few others did (Green, 2017).

In 2015, the Trump campaign had rejected an overture from Cambridge Analytica, reportedly because it believed the firm charged too much (Vogel and Samuelsohn, 2016). In May, however, with Cruz out, negotiations to bring Cambridge Analytica into the campaign began again. After Steve Bannon introduced Alexander Nix, the head of the firm, to the Trump campaign people, Nix made another approach (Ballhaus and Bykowicz, 2017). The evidence suggests that Cambridge was enthusiastic, but the Trump camp was divided. In early June, before any agreement had been reached, Cambridge sent a "small team" to work with the campaign's Texas-based digital operation (Ballhaus and Bykowicz, 2017). Brad Parscale, a principal in the latter, served as Trump's digital director. Parscale reportedly favored striking an arrangement with Cambridge, but Paul Manafort did not (Vogel and Samuelsohn, 2016).

Nevertheless, as Politico reported "in GOP finance circles, hiring Cambridge Analytica is widely seen as a way to increase the likelihood of winning support from the Mercers" (Vogel and Samuelsohn, 2016). On June 13, Cambridge reportedly dispatched a contract to the campaign, which Nix and someone representing Cambridge signed on June 23 (Ballhaus and Bykowicz, 2017). At the end of June, with the gender makeup of Trump's mostly male entourage clearly emerging as an issue, Conway came aboard as a campaign operative working under Manafort (Sullivan, 2016).

In the meantime, the process of reconciling with the rest of the party bogged down. By late July, the campaign's cash inflows were plainly lagging behind the levels of Romney in 2012, Obama in 2008, or Hillary Clinton in 2016. Sheldon Adelson and many other donors who were reported in the press to be close to Trump or considering supporting him were not actually contributing or had contributed only modest amounts (e.g., Carl Icahn). The Kochs were not enlisting, and never would. Contributions from defense and aerospace firms lagged well behind levels typical of past Republican presidential efforts. Describing the campaign's financing as collapsing would be excessive; but it was not on track to deliver what was the campaign plainly would need. Some of the slow progress almost certainly traced to doubts among traditional Republican-inclined industries and investors put off by Trump's continuing outbursts and friendly comments about Russia.

The campaign eventually responded by launching another highly publicized push for funds from small donors, with promises of a match from Trump (Kaye, 2016). That brought in some money, but nothing like what was needed. (In the final weeks of the campaign, small contributions actually tailed off.) 
In mid-August, as Trump sank lower in the polls, the crisis came to a head. Rebekah Mercer had her fateful conversation with Trump at a fundraiser. Manafort, already under pressure from a string of reports about his ties with the Ukraine and Russia, was first demoted and then fired. Steve Bannon took over direction of the campaign and Kellyanne Conway was promoted to campaign manager (Green, 2017).

Bannon's confidence that "If the left is focused on race and identity, and we go with economic nationalism, we can crush the Democrats" became famous only after the election (Kuttner, 2017). But within hours after Bannon and Conway took over, press accounts reported that "Bannon and Conway have decided to target five states and want to devote the campaign's time and resources to those contests: Florida, North Carolina, Virginia, Ohio and Pennsylvania. It is in those states where they believe Trump's appeal to working-class and economically frustrated voters has the best chance to resonate." (Costa et al., 2016). Their strategy clearly evolved to embrace a few other states, but this retargeting had a vital counterpart on the financial side.

The focus on the old industrial states attracted more money from steel, rubber, machinery, and other companies whose impulses to protection figured to benefit from this focus. But the bigger story over the next few weeks was the vast wave of new money that flowed into the campaign from some of America's biggest businesses and most famous investors. Sheldon Adelson and many others in the casino industry delivered in grand style for its old colleague. Adelson now delivered more than $\$ 11$ million in his own name, while his wife and other employees of his Las Vegas Sands casino gave another \$20 million. Peter Theil contributed more than a million dollars, while large sums also rolled in from other parts of Silicon Valley, including almost two million dollars from executives at Microsoft and just over two million from executives at Cisco Systems.

A wave of new money swept in from large private equity firms, the part of Wall Street which had long championed hostile takeovers as a way of disciplining what they mocked as bloated and inefficient "big business." Virtual pariahs to main-line firms in the Business Roundtable and the rest of Wall Street, some of these figures had actually gotten their start working with Drexel Burnham Lambert and that firm's dominant partner, Michael Milkin. Among those were Nelson Peltz and Carl Icahn (who had both contributed to Trump before, but now made much bigger new contributions). In the end, along with oil, chemicals, mining and a handful of other industries, large private equity firms would become one of the few segments of American business - and the only part of Wall Street - where support for Trump was truly heavy. ${ }^{59}$

In the final weeks of the campaign, a giant wave of dark money flowed into the campaign. Because it was dark the identity of the donors is shrouded. But our scrutiny of past cases where court litigation brought to light the true contributors suggests that most of this money probably came from the same types of firms that show up in the published listings. In our data, the sudden influx of money from private equity and hedge funds clearly began with the Convention but turned into a torrent only after Bannon and Conway took over. We are interested to see that after the election some famous private equity managers who do not appear in the visible roster of campaign donors showed up prominently around the President. An educated guess on the sources of some of that mighty wave is thus not difficult to make, though the timing of the inflow from the big 
private equity firms by itself is suggestive. In the end, total spending on behalf of Trump from all sources totaled about $\$ 1.2$ billion, not much less than the Clinton campaign's $\$ 1.4$ billion (including Super Pacs, etc.).

\section{The Failure of Clinton "Centrism": American Trasformismo}

Most accounts treat the Clinton campaign after the Democratic Convention as a study in confusion and infighting. We do not doubt there was plenty of both (Allen and Parnes, 2017) (Brazile, 2017). But our data suggest other lines of analysis, too. In particular, if one looks at the Clinton campaign's fundraising, it is immediately apparent that it was trying to run an American version of the famous "Trasformismo" system pioneered by a succession of center-right Italian politicians in the decades before World War I. The basic idea of that system was simple: put measured representatives of the left and right centers together against extremes, especially from the left.

We have already observed that the reconciliation between establishment Republicans and Trump around Convention time was only partial. Holdouts and skeptics were abundant. They were especially prominent among Neoconservatives and traditional internationalists who were appalled by Trump's talk of America First and his friendliness toward Russia. Many signed public letters and manifestos denouncing Trump, in some cases indicating they might be receptive to Clinton.

The Clinton campaign had been setting up an opening to the Neo-Conservatives and disenchanted Republicans for a long time (Karni, 2016). Throughout the campaign and in her post-election memoir, Clinton liked to portray herself to voters as continuing the legacy of President Obama. In foreign policy, this was something of a stretch. In fact she deliberately moved to the President's right on major security and foreign policy issues. As the situation in Syria became more and more intense, the campaign let it be known that their candidate differed from Obama's very careful stance against intervention. The possibility that substantial portions of the public might be tired of endless wars does not seem to have crossed anyone's mind (Kriner and Shen, 2017).

When Trump opened up on the Bush and Obama policies toward Iraq, Syria, Ukraine, Russia, and Afghanistan, Clinton's move to the right in these areas persuaded many so-called "Neo-Conservatives" that they should seriously consider supporting her. Her stalwart defense of Wall Street, and doubts that Trump could be trusted with command of nuclear weapons, along with the universal conviction she was the likely winner, enhanced her attractiveness to these groups and to many other business interests that normally leaned Republican. As our Table 7 shows, Trump trailed well behind Clinton in contributions from defense and aerospace - a lack of support that we consider extraordinary for a Republican presidential hopeful this late in the race (compare with the corresponding table for Romney in (Ferguson et al., 2013).

For Clinton's campaign the temptation was irresistible: Over time it slipped into a variant of the strategy Lyndon Johnson pursued in 1964 in the face of another candidate who seemed too far out of the mainstream to win: Go for a grand coalition with most of 
big business. Just as in 1964, this super-charged the campaign's finances - a temptation that the Clintons could rarely resist. But in contrast to 1964, when Johnson ran as the candidate of peace and prosperity, the gambit carried with it unrecognized electoral risks that the Trump campaign ultimately exploited, not only in regard to economics, but in foreign policy as well (Kriner and Shen, 2017). And, as will become clearer below, one fateful consequence of trying to appeal to so many conservative business interests was strategic silence about most important matters of public policy. Given the candidate's steady lead in the polls, there seemed to be no point to rocking the boat with any more policy pronouncements than necessary. When in the final days the campaign woke up to the fact that it was in the Twilight Zone, it was too late.

The campaign also quietly maintained relatively hard lines on economic policy, which advisers signaled by their choice of models that suggested the US would soon return to full employment, and by the economists who were given major access. (Indeed, after arguing strenuously throughout the campaign that the Fed should not raise interest rates, many Democratic economists switched gears within days after the election and started beating drums in favor of rate rises.) Misgivings of major contributors who worried that the Clinton campaign message lacked real attractions for ordinary Americans were rebuffed. The campaign sought to capitalize on the angst within business by vigorously courting the doubtful and undecideds there, not in the electorate. The result is evident in our Table 7, in which - with the possible exception of 1964 - the Clinton campaign looks like no other Democratic campaign since the New Deal. The Clinton campaign reached far into sectors and firms that have rarely supported any Democrat. The strong resemblance to the profile of the Romney campaign in 2012 in many (though not all) particulars is striking (see, again, Table 3, above and the industrial breakdowns presented in (Ferguson et al., 2013).

Table 7 About Here

This monetary breadth came at a cost: The effort to reach out to big business had no hope of success if the candidate vigorously promoted policies along the lines Sanders had proposed. The evidence suggests that the campaign realized this: Though it constantly complained that the media ignored its policy proposals, it also talked less about policy than any other campaign for which we have measurements. Instead, it stressed candidate qualifications (Fowler et al., 2016). Even in the final days, it deliberately deemphasized issues in favor of concentrating on what the campaign regarded as Trump's obvious personal weaknesses as a candidate. (Clinton, 2017).

It was a miscalculation of historic proportions. The evidence suggests that Bannon and Conway were right. On election night, as Democratic hopes for control of the Senate 
collapsed, the Clinton campaign fell victim to the American electoral counterpart of the Curse of Midas. In the electorate as a whole, the Trump campaign's racism and misogyny appears to have cost it some votes. But just enough voters were turned off by years of economic stagnation and painful wars to allow Donald Trump - despite finishing behind Clinton in the popular vote -to slip into the White House (Ferguson and Page, 2017) (Monnat and Brown, 2017).

\section{Conclusion: The Political Economy of a Collapsing Party System}

Business contributions to Donald Trump's inaugural celebration broke all records. In contrast to his campaign which, as we have seen, stimulated truly substantial amounts of small contributions, the inaugural donations were on average gigantic. As Table 8 shows, 93\% of them exceeded $\$ 100,000$, with an average value of almost $\$ 406,000 .^{60}$

Table 8 About Here

It is too clever by half to dismiss these sums worthy of the Gilded Age as misplaced investments simply because of the slow pace of Congressional legislation. Trump and his allies do not need Congressional action to send rivers of cash flowing to many supporters. A wide range of executive actions and deliberate shifts of institutional priorities is already benefiting enormous numbers of them.

But our analysis of the political economy of the 2016 campaign points to sharp limits on what Trump or any other political force now operating can hope to achieve. The emergence of a full blown dual economy means that the system no longer works for many Americans. Spatial imbalances in economic growth, the declining welfare state, and insistent pressures to cut expenditures to lower taxes on the rich throw enormous stresses on average Americans. Many realize that their wages and working conditions are deteriorating, and that the challenges facing their children are intense.

The result was the vast mobilizations against the establishments of both major parties that dominated the 2016 presidential struggle. Trump's triumph came over the bitter opposition of older Republican elites; while the Clinton campaign had to pull out all the stops to contain the wave of protests from millions of ordinary Americans who actively supported an insurgent candidate running openly as a democratic socialist. In both parties, the new energy coming into the system from ordinary Americans is obvious. It fills many in power now with dread.

We are extremely skeptical that there is any way to put these genies back in the bottle. Very early in Trump's tenure, he essentially lost control of most policy on national security and 
was forced to make appointments that represented quite different points of view on policy toward Russia and, with some qualifications, China. Tensions between Trump and Republican Congressional leaders clearly run deep; their donor universes are strikingly different, as we will show on another occasion.

Trump's own coalition is extremely unstable. Our analysis of how it developed over time reveals that it is made up of several layers of investor blocs with little in common other than their intense dislike of existing forms of American government. The world of private equity, intent on gaining access to the gigantic, rapidly growing securities markets of China and the rest of Asia or casinos dependent on licenses for their lucrative businesses in Macau are likely to coexist only fitfully with American industries struggling to cope with world overcapacity in steel and other products or facing twenty-first century mercantilist state targeting. ${ }^{61}$ Substituting Mike Pence for Donald Trump would not change any of this nor would it end the all-out war on the GOP establishment that Bannon and his allies are waging.

Within the Democratic Party, the desires of party leaders who to continue to depend on big money from Wall Street, Silicon Valley, health insurers, and other power centers collides head on with the needs of average Americans Party leaders claim to defend. On medical care, minimum wages, unionization, and many other issues, there is no consensus; only intense wrangling behind a cloud of opaque rhetoric and increasingly hollow "resist" slogans.

Meanwhile big finance and the telecom giants intensify their pushes to be free of deregulation, while traditional patterns of alliances dissolve as the relative position of the U.S. in the global system alters. Trump's triumph, with its powerful overtones of bait and switch, is a moment in the disintegration of a money-driven political system that is now appears trapped in a fatal circle of corruption and cynicism. 2016 showed that mass citizen involvement can dramatically reshape politics, but it also highlights the essential point of the investment approach to politics, which is the enormous advantages elites normally retain in political action. 
Table 1

Union Membership Decline 2008-16:

Three Non-Southern Battleground States That Clinton Narrowly Lost All Rank At or Near Top -- States in Italics

\begin{tabular}{|c|l|}
\hline Wisconsin & 6.9 \\
\hline Alaska & 5.2 \\
\hline Hawaii & 4.7 \\
\hline Nevada & 4.6 \\
\hline Michigan & 4.4 \\
\hline Arizona & 4.3 \\
\hline Massachusetts & 3.7 \\
\hline Pennsylvania & 3.4 \\
\hline
\end{tabular}

In Order From Top; National Average Decline: 1.70

Source: Calculated From Data in (Hirsch and Machpherson, 2017). 
Figure 1

The Last-minute Surge of Dark Money for Trump in 2016

Far Exceeded That for Romney in 2012

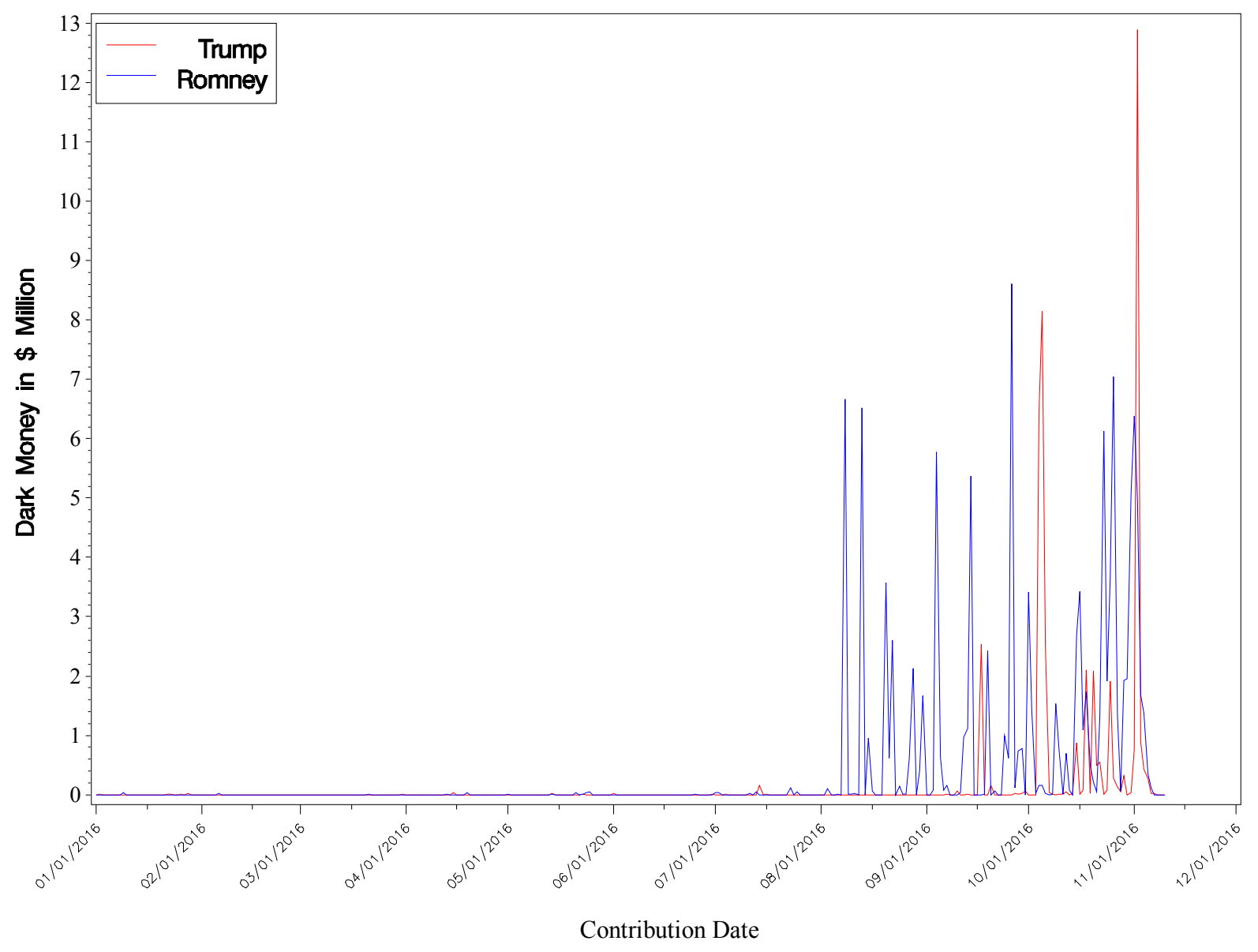

Source: Computed by Authors From FEC and IRS Data 
Figure 2

The Simultaneous Late October Fall of Democratic Senate Hopes With Clinton Decline

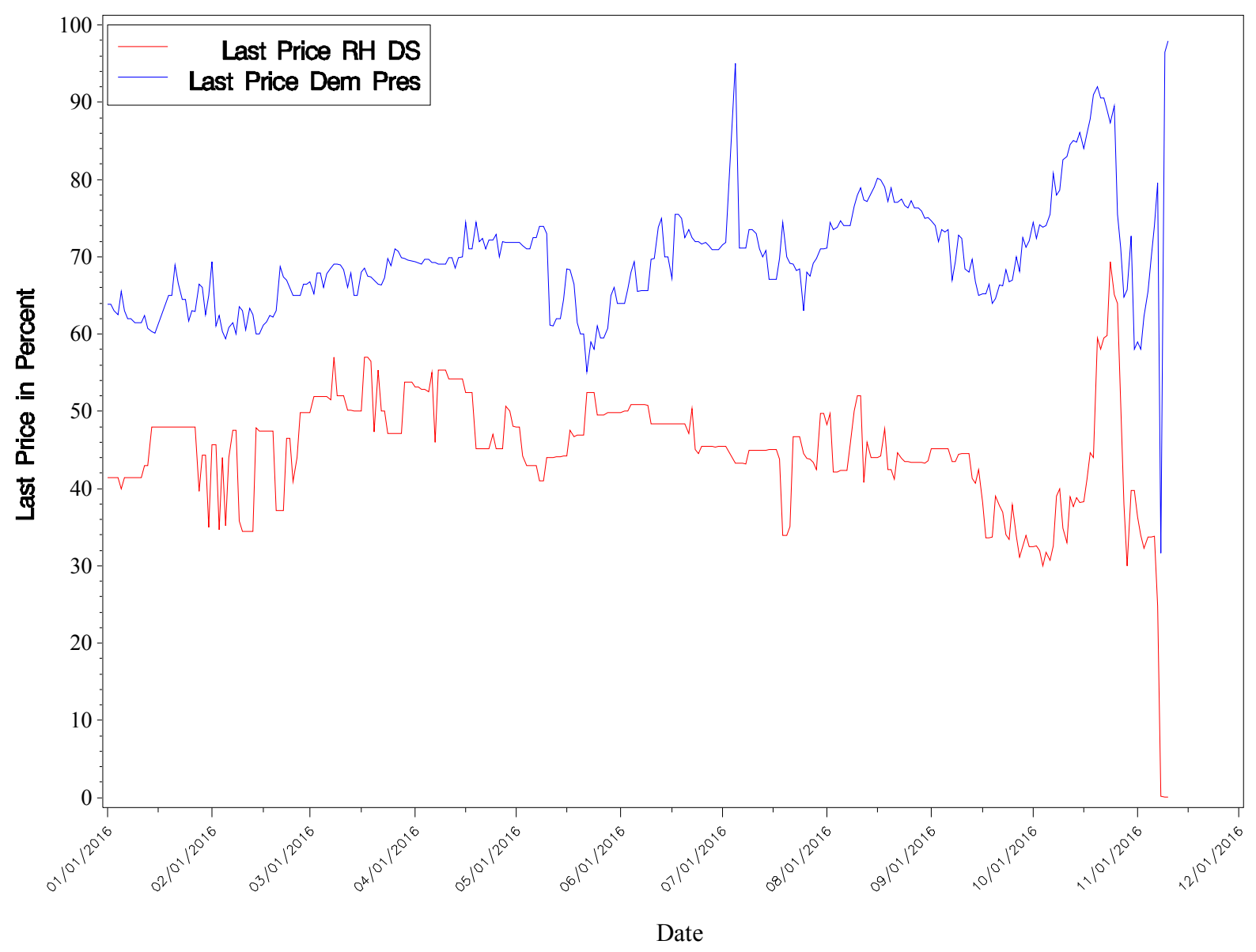

Iowa Electronic Market Prices for Clinton Presidency and for Republican House plus Democratic Senate

Source: Iowa Market Data, https://tippie.biz.uiowa.edu/iem/ 
Table 2

2016 Presidential Candidates

Breakdown of Contributions by Size, Grouped by "Firms." Includes Super PACs, Independent Expenditures, and Other Forms of Big Money (As \% of Total Contributions)

Democratic Candidates

Total Amount
$<200$ (UNITEMIZED)
$<=250$
$251-499$
$500-999$
$1000-9999$
$10000-99999$
$>=100000$

Clinton
17
2
2
3
16
13
48

Sanders
59
6
6
8
16
2
3

$\begin{array}{cc}\text { O'Malley } & \text { Webb } \\ 9.5 & 42.5 \\ 2 & 3.9 \\ .6 & 1 \\ 4.9 & 9 \\ 57.3 & 39.5 \\ 13.9 & 4.1 \\ 11.8 & 0\end{array}$

Republican Candidates

$\begin{array}{cccccc}\text { Total Amount } & \text { Trump } & \text { Bush } & \text { Carson } & \text { Christie } & \text { Cruz } \\ <200 \text { (UNITEMIZED) } & 37.56 & 1.7 & 57 & 1.6 & 27 \\ <=250 & 2.02 & .1 & 5 & .3 & 4 \\ 251-499 & 1.08 & .1 & 5 & .2 & 3 \\ 500-999 & 2.62 & .6 & 8 & .8 & 5 \\ 1000-9999 & 9.25 & 19.8 & 20 & 26.1 & 19 \\ 10000-99999 & 6.88 & 25.2 & 3 & 15.2 & 7 \\ >=100000 & 40.58 & 52.5 & 2 & 55.8 & 34 \\ \text { Total Amount } & \text { Fiorina } & \text { Gilmore } & \text { Graham } & \text { Huckabee } & \text { Jindal } \\ <200 \text { (UNITEMIZED) } & 27.2 & .9 & 2.8 & 27.4 & 2.3 \\ <=250 & 2.4 & .5 & .4 & 1.6 & .3 \\ 251-499 & 1.8 & .1 & .4 & 1 & .1 \\ 500-999 & 4.8 & 1.4 & 1.8 & 2.8 & .5 \\ 1000-9999 & 17.9 & 20.5 & 33.2 & 19.2 & 21.1 \\ 10000-99999 & 7.9 & 29.4 & 21 & 2.9 & 20.1 \\ >=100000 & 37.9 & 47.3 & 40.5 & 45.1 & 55.6 \\ & & & & & \\ \text { Total Amount } & \text { Kasich } & \text { Pataki } & \text { Paul } & \text { Perry } & \text { Rubio } \\ <200 \text { (UNITEMIZED) } & 5.7 & 1.5 & 22.1 & 3.1 & 10.4 \\ <=250 & 1 & 1 & 2.3 & .6 & .8 \\ 251-499 & .5 & .1 & 1.5 & .1 & 1.2 \\ 500-999 & 1.4 & 1.3 & 3.1 & 1 & 2.7\end{array}$




$\begin{array}{cccccc}1000-9999 & 14.1 & 27.5 & 14.7 & 28.8 & 23.2 \\ 10000-99999 & 8.2 & 55.4 & 9.1 & 18.5 & 6.2 \\ >=100000 & 69.2 & 13.1 & 47.1 & 47.9 & 55.5 \\ & & & & & \\ \text { Total Amount } & \text { Santorum } & \text { Walker } & & \\ <200 \text { (UNITEMIZED) } & 13.6 & 13.3 & & \\ <=250 & 1.6 & .7 & & \\ 251-499 & 1.2 & .6 & & \\ 500-999 & 3.5 & 2.4 & & \\ 1000-9999 & 37.5 & 19.5 & & \\ 10000-99999 & 9.3 & 18.6 & & \\ >=100000 & 33.3 & 45 & & \end{array}$

Source: Computed by Authors From FEC and IRS Data 
Table 3

Size Comparison of 2016 and 2012 Contributions

(Numbers Are Rounded)

Breakdown of All Itemized Contributions, Grouped by "Firms," Percentages of Totals Including Super PACs, Independent Expenditures, and Other Forms of Big Money by Size (in \% of All Contributions to Candidate)

$\begin{array}{ccccc}\text { Total Amount } & \text { Trump } 2016 & \text { Sanders } 2016 & \text { Obama } 2012 & \text { Romney } 2012 \\ <200 \text { (UNITEMIZED) } & 38 & 59 & 37 & 18 \\ <=250 & 2 & 6 & 2 & 1 \\ 251-499 & 1 & 6 & 2 & 1 \\ 500-999 & 3 & 8 & 3 & 3 \\ 1000-9999 & 9 & 16 & 15 & 17 \\ 10000-99999 & 7 & 2 & 21 & 23 \\ >=100000 & 41 & 3 & 20 & 36\end{array}$

$\begin{array}{cc}\text { Total Amount } & \text { Clinton } 2016 \\ <200 \text { (UNITEMIZED) } & 17 \\ <=250 & 2 \\ 251-499 & 2 \\ 500-999 & 3 \\ 1000-9999 & 16 \\ 10000-99999 & 13 \\ >=100000 & 48\end{array}$

Source: Computed by Authors From FEC and IRS Data 
Table 4

Industrial Structure and the GOP Race

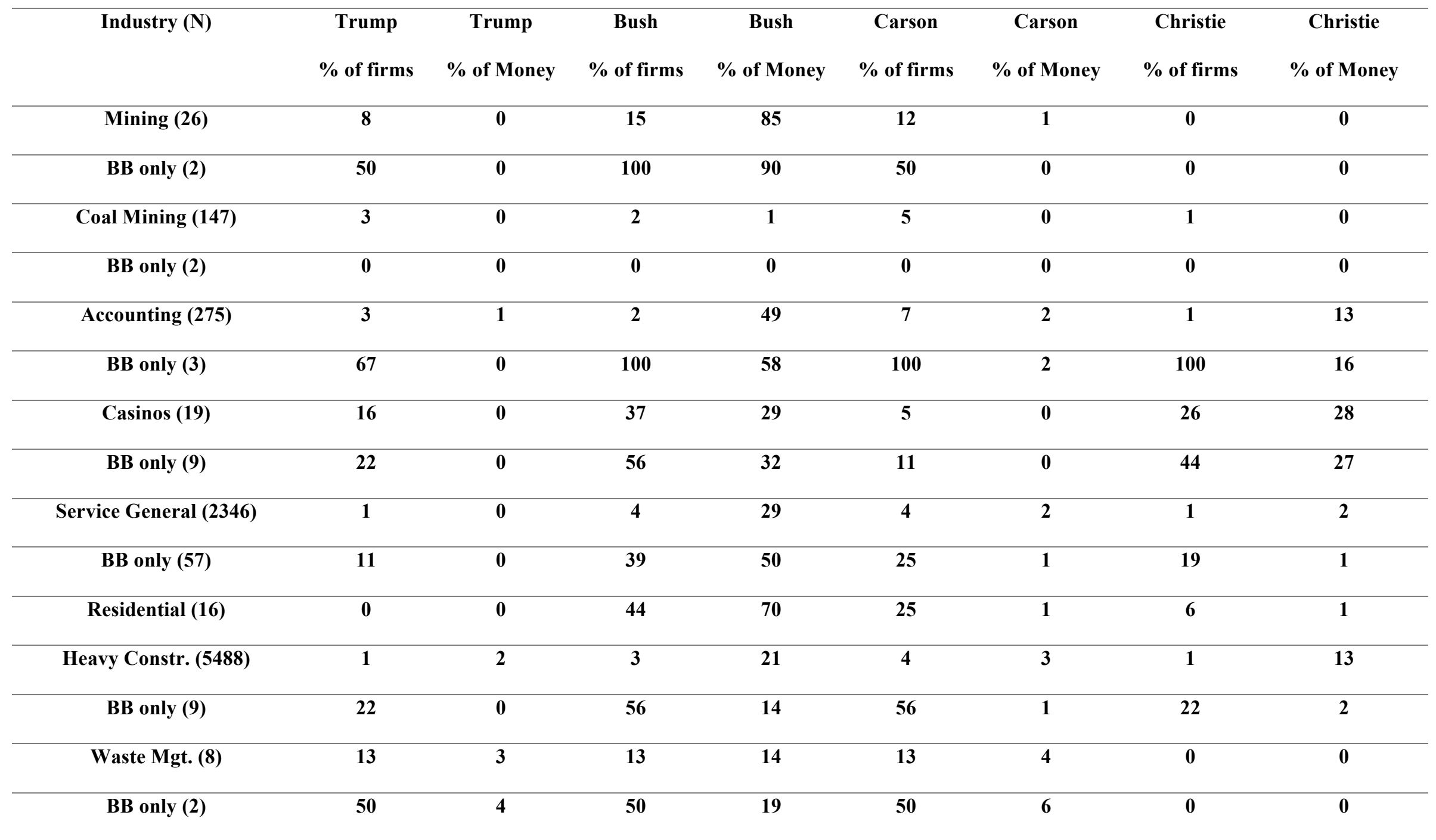




\begin{tabular}{|c|c|c|c|c|c|c|c|c|}
\hline Food (1668) & 1 & 1 & 3 & 48 & 4 & 3 & 1 & 9 \\
\hline BB only (34) & 12 & 1 & 29 & 62 & 32 & 2 & 15 & 4 \\
\hline Tobacco (15) & $\mathbf{0}$ & $\mathbf{0}$ & 20 & 31 & 20 & 4 & $\mathbf{0}$ & $\mathbf{0}$ \\
\hline BB only (3) & $\mathbf{0}$ & $\mathbf{0}$ & 67 & 23 & 100 & 5 & $\mathbf{0}$ & $\mathbf{0}$ \\
\hline Textiles (13) & 8 & $\mathbf{0}$ & $\mathbf{0}$ & $\mathbf{0}$ & 23 & 8 & $\mathbf{0}$ & $\mathbf{0}$ \\
\hline Apparel (23) & 4 & 1 & 22 & 9 & 9 & 1 & 9 & 1 \\
\hline BB only (5) & $\mathbf{0}$ & $\mathbf{0}$ & 60 & 3 & 40 & 1 & 40 & 1 \\
\hline Agribusiness (120) & 1 & $\mathbf{0}$ & 3 & 13 & 3 & 1 & 1 & $\mathbf{0}$ \\
\hline Paper (300) & 2 & $\mathbf{0}$ & 6 & 27 & 8 & 1 & 2 & 1 \\
\hline BB only (8) & 25 & $\mathbf{0}$ & 50 & 6 & 63 & 1 & $\mathbf{0}$ & $\mathbf{0}$ \\
\hline Printing and Pub (14) & 21 & 2 & 21 & 67 & 21 & 2 & $\mathbf{0}$ & $\mathbf{0}$ \\
\hline BB only (1) & 100 & 2 & 100 & 92 & 100 & $\mathbf{0}$ & $\mathbf{0}$ & $\mathbf{0}$ \\
\hline Chemical (695) & 3 & 2 & 5 & 39 & 8 & 4 & 1 & 1 \\
\hline BB only (16) & 19 & $\mathbf{0}$ & 50 & 49 & 50 & 6 & 13 & 3 \\
\hline Oil (3987) & 2 & $\mathbf{0}$ & 5 & 41 & 6 & 1 & 1 & 3 \\
\hline BB only (62) & 23 & $\mathbf{0}$ & 56 & 44 & 39 & 1 & 6 & 2 \\
\hline Rubber (318) & 3 & 1 & 2 & 18 & 8 & 10 & $\mathbf{0}$ & $\mathbf{0}$ \\
\hline BB only (1) & $\mathbf{0}$ & $\mathbf{0}$ & $\mathbf{0}$ & $\mathbf{0}$ & 100 & 12 & $\mathbf{0}$ & $\mathbf{0}$ \\
\hline
\end{tabular}




\begin{tabular}{|c|c|c|c|c|c|c|c|c|}
\hline Industry (N) & Trump & Trump & Bush & Bush & Carson & Carson & Christie & Christie \\
\hline & $\%$ of firms & \% of Money & $\%$ of firms & \% of Money & $\%$ of firms & \% of Money & $\%$ of firms & \% of Money \\
\hline Glass (339) & 2 & $\mathbf{0}$ & 1 & 62 & 6 & 16 & 1 & 4 \\
\hline BB only (2) & $\mathbf{0}$ & $\mathbf{0}$ & 100 & 97 & $\mathbf{0}$ & $\mathbf{0}$ & 50 & 3 \\
\hline Steel (1214) & 2 & 2 & 3 & 31 & 6 & 10 & $\mathbf{0}$ & 1 \\
\hline BB only (6) & 17 & 4 & 33 & 21 & 67 & 33 & 17 & 1 \\
\hline Cosmetics (16) & $\mathbf{0}$ & $\mathbf{0}$ & 31 & 17 & 13 & $\mathbf{0}$ & 6 & $\mathbf{0}$ \\
\hline BB only (9) & $\mathbf{0}$ & $\mathbf{0}$ & 44 & 19 & 22 & $\mathbf{0}$ & 11 & $\mathbf{0}$ \\
\hline Altern Energy (22) & 5 & 2 & $\mathbf{0}$ & $\mathbf{0}$ & $\mathbf{0}$ & $\mathbf{0}$ & $\mathbf{0}$ & $\mathbf{0}$ \\
\hline Electronics (121) & 12 & 1 & 10 & 8 & 28 & 7 & 5 & 5 \\
\hline BB only (13) & 23 & 1 & 38 & 14 & 62 & 7 & 15 & 3 \\
\hline Guns, Ammo (8) & 13 & 7 & 13 & 15 & 25 & 11 & $\mathbf{0}$ & $\mathbf{0}$ \\
\hline Machinery (222) & 4 & $\mathbf{0}$ & 8 & 13 & 15 & 3 & 3 & 12 \\
\hline BB only (14) & 29 & $\mathbf{0}$ & 36 & 13 & 57 & 5 & 36 & 30 \\
\hline Defense Prod and Serv (19) & $\mathbf{0}$ & $\mathbf{0}$ & 11 & 7 & 11 & 3 & 5 & 1 \\
\hline Autos (97) & 7 & 1 & 6 & 27 & 19 & 14 & 2 & 7 \\
\hline BB only (12) & 17 & 1 & 25 & 36 & 42 & 14 & 8 & 2 \\
\hline Aerospace (31) & 19 & 1 & 26 & 14 & 32 & 11 & 16 & 2 \\
\hline BB only (9) & 67 & 1 & 78 & 14 & 89 & 11 & 56 & 2 \\
\hline
\end{tabular}




\begin{tabular}{|c|c|c|c|c|c|c|c|c|}
\hline Pharma (587) & 3 & 2 & 6 & 20 & 8 & 3 & 3 & 31 \\
\hline BB only (18) & 28 & 1 & 61 & 28 & 56 & 4 & 22 & 5 \\
\hline Computers (41) & 20 & 1 & 27 & 20 & 32 & 4 & 15 & 35 \\
\hline BB only (17) & 24 & 1 & 41 & 21 & 29 & 3 & 18 & 38 \\
\hline Internet Mfgr (17) & 41 & 1 & 24 & 10 & 47 & 7 & 18 & 5 \\
\hline BB only (2) & 100 & 1 & 100 & 5 & 100 & 6 & 50 & 5 \\
\hline Software (138) & 15 & $\mathbf{0}$ & 19 & 6 & 22 & 1 & 9 & 2 \\
\hline BB only (30) & 20 & $\mathbf{0}$ & 30 & 4 & 27 & $\mathbf{0}$ & 17 & $\mathbf{0}$ \\
\hline Telecom (1552) & 2 & $\mathbf{0}$ & 4 & 11 & 5 & 1 & 2 & 2 \\
\hline BB only (49) & 20 & $\mathbf{0}$ & 43 & 9 & 29 & $\mathbf{0}$ & 20 & 1 \\
\hline \multirow[t]{2}{*}{ Industry (N) } & Trump & Trump & Bush & Bush & Carson & Carson & Christie & Christie \\
\hline & $\%$ of firms & \% of Money & $\%$ of firms & \% of Money & $\%$ of firms & \% of Money & $\%$ of firms & \% of Money \\
\hline Beverages (38) & 11 & 1 & 34 & 31 & 18 & 7 & 11 & 2 \\
\hline BB only (5) & 40 & $\mathbf{0}$ & 80 & 27 & 40 & 7 & 20 & $\mathbf{0}$ \\
\hline Health (29951) & 1 & 2 & 2 & 40 & 7 & 7 & 1 & 6 \\
\hline BB only (18) & 28 & 1 & 28 & 52 & 56 & 5 & 22 & 1 \\
\hline Health Insur. (23) & 30 & $\mathbf{0}$ & 48 & 48 & 52 & 5 & 26 & 5 \\
\hline BB only (10) & 50 & 1 & 100 & 48 & 90 & 5 & 60 & 6 \\
\hline
\end{tabular}




\begin{tabular}{|c|c|c|c|c|c|c|c|c|}
\hline Credit Reporting (10) & 10 & $\mathbf{0}$ & 60 & 75 & 60 & $\mathbf{0}$ & 10 & $\mathbf{0}$ \\
\hline BB only (2) & $\mathbf{0}$ & $\mathbf{0}$ & 100 & 92 & 100 & $\mathbf{0}$ & $\mathbf{0}$ & $\mathbf{0}$ \\
\hline Auto Dealers (3188) & 1 & $\mathbf{0}$ & 3 & 6 & 2 & 1 & $\mathbf{0}$ & 1 \\
\hline BB only (7) & $\mathbf{0}$ & $\mathbf{0}$ & 43 & $\mathbf{0}$ & 29 & $\mathbf{0}$ & $\mathbf{0}$ & $\mathbf{0}$ \\
\hline Transp, Trk, RR (1659) & 2 & 1 & 3 & 45 & 5 & 3 & $\mathbf{0}$ & $\mathbf{0}$ \\
\hline BB only (11) & 36 & $\mathbf{0}$ & 36 & 75 & 45 & 2 & $\mathbf{0}$ & $\mathbf{0}$ \\
\hline Airlines (14) & 43 & 2 & 36 & 11 & 50 & 16 & 29 & 1 \\
\hline BB only (4) & 100 & 3 & 75 & 5 & 100 & 17 & 75 & 1 \\
\hline Utilities (2582) & 1 & 1 & 2 & 51 & 5 & 3 & 1 & 12 \\
\hline BB only (19) & 42 & $\mathbf{0}$ & 63 & 61 & 79 & 1 & 37 & 14 \\
\hline Commun (14) & 7 & $\mathbf{0}$ & 29 & 5 & 14 & $\mathbf{0}$ & 14 & 37 \\
\hline BB only (5) & 20 & $\mathbf{0}$ & 40 & 4 & 20 & $\mathbf{0}$ & 40 & 37 \\
\hline Mortg and Non-Bk Lending (136) & 1 & $\mathbf{0}$ & 11 & 18 & 8 & $\mathbf{0}$ & 3 & 49 \\
\hline BB only (5) & $\mathbf{0}$ & $\mathbf{0}$ & 60 & 1 & 40 & $\mathbf{0}$ & 20 & 64 \\
\hline Real Estate (12451) & 1 & 4 & 3 & 37 & 4 & 3 & 1 & 7 \\
\hline BB only (36) & 3 & $\mathbf{0}$ & 25 & 22 & 6 & 1 & 11 & 2 \\
\hline Insurance (4927) & 1 & 1 & 3 & 34 & 3 & 5 & 1 & 3 \\
\hline BB only (35) & 46 & 1 & 63 & 46 & 71 & 10 & 34 & 3 \\
\hline Comm Banking (3971) & 1 & 2 & 4 & 46 & 5 & 2 & 1 & 1 \\
\hline
\end{tabular}




\begin{tabular}{|c|c|c|c|c|c|c|c|c|}
\hline BB only (18) & 56 & 3 & 72 & 49 & 50 & 1 & 50 & 1 \\
\hline Invest and Hedge Funds (285) & 4 & 1 & 21 & 11 & 4 & $\mathbf{0}$ & 5 & 8 \\
\hline BB only (47) & 9 & 2 & 40 & 15 & 6 & $\mathbf{0}$ & 15 & 14 \\
\hline Priv Equity (14880) & 1 & 1 & 7 & 33 & 3 & 1 & 1 & 8 \\
\hline BB only (38) & 3 & $\mathbf{0}$ & 21 & 22 & 3 & $\mathbf{0}$ & 5 & 1 \\
\hline Brokers, Mut Fd (43) & 21 & $\mathbf{0}$ & 28 & 53 & 33 & 2 & 12 & 4 \\
\hline BB only (6) & 33 & $\mathbf{0}$ & 67 & 91 & 33 & 2 & 17 & $\mathbf{0}$ \\
\hline Retailing (195) & 10 & $\mathbf{0}$ & 21 & 20 & 28 & 1 & 8 & 5 \\
\hline BB only (68) & 21 & $\mathbf{0}$ & 40 & 17 & $\mathbf{5 0}$ & 1 & 10 & 5 \\
\hline 100 Small Bus nec (512364) & 1 & 2 & 1 & 27 & 3 & 4 & $\mathbf{0}$ & 6 \\
\hline \multirow[t]{2}{*}{ Industry $(\mathbf{N})$} & Cruz & Cruz & Fiorina & Fiorina & Gilmore & Gilmore & Graham & Graham \\
\hline & \% of firms & $\begin{array}{c}\text { \% of } \\
\text { Money }\end{array}$ & \% of firms & $\begin{array}{c}\text { \% of } \\
\text { Money }\end{array}$ & \% of firms & \% of Money & $\%$ of firms & $\begin{array}{c}\text { \% of } \\
\text { Money }\end{array}$ \\
\hline Mining (26) & 35 & 9 & $\mathbf{0}$ & $\mathbf{0}$ & $\mathbf{0}$ & $\mathbf{0}$ & $\mathbf{0}$ & $\mathbf{0}$ \\
\hline BB only (2) & 50 & 7 & $\mathbf{0}$ & $\mathbf{0}$ & $\mathbf{0}$ & $\mathbf{0}$ & $\mathbf{0}$ & $\mathbf{0}$ \\
\hline Coal Mining (147) & 11 & 12 & 3 & 3 & $\mathbf{0}$ & $\mathbf{0}$ & 1 & $\mathbf{0}$ \\
\hline BB only (2) & $\mathbf{0}$ & $\mathbf{0}$ & $\mathbf{0}$ & $\mathbf{0}$ & $\mathbf{0}$ & $\mathbf{0}$ & $\mathbf{0}$ & $\mathbf{0}$ \\
\hline Accounting (275) & 9 & 5 & 3 & 1 & $\mathbf{0}$ & $\mathbf{0}$ & 1 & 1 \\
\hline BB only (3) & 100 & 4 & 100 & 1 & $\mathbf{0}$ & $\mathbf{0}$ & 100 & 1 \\
\hline
\end{tabular}




\begin{tabular}{|c|c|c|c|c|c|c|c|c|}
\hline Casinos (19) & 37 & 14 & 5 & 13 & $\mathbf{0}$ & $\mathbf{0}$ & 11 & 7 \\
\hline BB only (9) & 56 & 13 & 11 & 15 & $\mathbf{0}$ & $\mathbf{0}$ & 22 & 8 \\
\hline Service General (2346) & 8 & 4 & 2 & 1 & $\mathbf{0}$ & $\mathbf{0}$ & 1 & $\mathbf{0}$ \\
\hline BB only (57) & 26 & 3 & 16 & $\mathbf{0}$ & $\mathbf{0}$ & $\mathbf{0}$ & 12 & 1 \\
\hline Residential (16) & 44 & 1 & $\mathbf{0}$ & $\mathbf{0}$ & $\mathbf{0}$ & $\mathbf{0}$ & $\mathbf{0}$ & $\mathbf{0}$ \\
\hline Heavy Constr. (5488) & 8 & 25 & 1 & 2 & $\mathbf{0}$ & $\mathbf{0}$ & $\mathbf{0}$ & 2 \\
\hline BB only (9) & 56 & 76 & 33 & 1 & $\mathbf{0}$ & $\mathbf{0}$ & 22 & 3 \\
\hline Waste Mgt. (8) & 63 & 41 & 13 & 16 & $\mathbf{0}$ & $\mathbf{0}$ & $\mathbf{0}$ & $\mathbf{0}$ \\
\hline BB only (2) & 100 & 22 & 50 & 22 & $\mathbf{0}$ & $\mathbf{0}$ & $\mathbf{0}$ & $\mathbf{0}$ \\
\hline Food (1668) & 8 & 6 & 1 & 1 & $\mathbf{0}$ & $\mathbf{0}$ & 1 & 3 \\
\hline BB only (34) & 59 & 5 & 6 & 1 & $\mathbf{0}$ & $\mathbf{0}$ & 12 & 7 \\
\hline Tobacco (15) & 20 & 5 & $\mathbf{0}$ & $\mathbf{0}$ & $\mathbf{0}$ & $\mathbf{0}$ & 7 & 18 \\
\hline BB only (3) & 100 & 6 & $\mathbf{0}$ & $\mathbf{0}$ & $\mathbf{0}$ & $\mathbf{0}$ & 33 & 22 \\
\hline Textiles (13) & 15 & 7 & $\mathbf{0}$ & $\mathbf{0}$ & $\mathbf{0}$ & $\mathbf{0}$ & 15 & 47 \\
\hline Apparel (23) & 9 & $\mathbf{0}$ & 4 & $\mathbf{0}$ & $\mathbf{0}$ & $\mathbf{0}$ & 9 & 35 \\
\hline BB only (5) & 20 & $\mathbf{0}$ & $\mathbf{0}$ & $\mathbf{0}$ & $\mathbf{0}$ & $\mathbf{0}$ & 20 & 40 \\
\hline Agribusiness (120) & 3 & 4 & 2 & 1 & $\mathbf{0}$ & $\mathbf{0}$ & 2 & 15 \\
\hline Paper (300) & 13 & 3 & 2 & $\mathbf{0}$ & $\mathbf{0}$ & $\mathbf{0}$ & 1 & 21 \\
\hline BB only (8) & 50 & 1 & 25 & $\mathbf{0}$ & $\mathbf{0}$ & $\mathbf{0}$ & 13 & 30 \\
\hline
\end{tabular}




\begin{tabular}{|c|c|c|c|c|c|c|c|c|}
\hline Printing and Pub (14) & 36 & 7 & 14 & 1 & $\mathbf{0}$ & $\mathbf{0}$ & $\mathbf{0}$ & $\mathbf{0}$ \\
\hline BB only (1) & 100 & 5 & $\mathbf{0}$ & $\mathbf{0}$ & $\mathbf{0}$ & $\mathbf{0}$ & $\mathbf{0}$ & $\mathbf{0}$ \\
\hline Chemical (695) & 15 & 11 & 2 & 1 & $\mathbf{0}$ & $\mathbf{0}$ & 1 & 4 \\
\hline BB only (16) & 63 & 7 & 25 & 2 & $\mathbf{0}$ & $\mathbf{0}$ & 19 & 16 \\
\hline Oil (3987) & 14 & 12 & 2 & 5 & $\mathbf{0}$ & $\mathbf{0}$ & $\mathbf{0}$ & 4 \\
\hline BB only (62) & 63 & 9 & 27 & 5 & $\mathbf{0}$ & $\mathbf{0}$ & 10 & 5 \\
\hline Rubber (318) & 14 & 27 & 3 & 11 & $\mathbf{0}$ & $\mathbf{0}$ & $\mathbf{0}$ & 1 \\
\hline BB only (1) & 100 & 17 & $\mathbf{0}$ & $\mathbf{0}$ & $\mathbf{0}$ & $\mathbf{0}$ & $\mathbf{0}$ & $\mathbf{0}$ \\
\hline \multirow[t]{2}{*}{ Industry (N) } & Cruz & Cruz & Fiorina & Fiorina & Gilmore & Gilmore & Graham & Graham \\
\hline & $\%$ of firms & $\%$ of Money & $\%$ of firms & $\%$ of Money & $\%$ of firms & $\%$ of Money & $\%$ of firms & $\%$ of Money \\
\hline Glass (339) & 11 & 7 & 2 & 1 & $\mathbf{0}$ & $\mathbf{0}$ & 1 & 1 \\
\hline BB only (2) & $\mathbf{0}$ & $\mathbf{0}$ & $\mathbf{0}$ & $\mathbf{0}$ & $\mathbf{0}$ & $\mathbf{0}$ & $\mathbf{0}$ & $\mathbf{0}$ \\
\hline Steel (1214) & 12 & 22 & 2 & 2 & $\mathbf{0}$ & $\mathbf{0}$ & $\mathbf{1}$ & $\mathbf{1}$ \\
\hline BB only (6) & 67 & 21 & 17 & 1 & $\mathbf{0}$ & $\mathbf{0}$ & $\mathbf{0}$ & $\mathbf{0}$ \\
\hline Cosmetics (16) & 31 & 18 & 25 & 19 & $\mathbf{0}$ & $\mathbf{0}$ & $\mathbf{0}$ & $\mathbf{0}$ \\
\hline BB only (9) & 56 & 21 & 33 & 21 & $\mathbf{0}$ & $\mathbf{0}$ & $\mathbf{0}$ & $\mathbf{0}$ \\
\hline Altern Energy (22) & 9 & 18 & $\mathbf{0}$ & $\mathbf{0}$ & $\mathbf{0}$ & $\mathbf{0}$ & 5 & 31 \\
\hline Electronics (121) & 53 & 26 & 13 & 6 & $\mathbf{0}$ & $\mathbf{0}$ & 4 & 10 \\
\hline BB only (13) & 85 & 23 & 23 & 1 & $\mathbf{0}$ & 0 & 15 & 25 \\
\hline
\end{tabular}




\begin{tabular}{|c|c|c|c|c|c|c|c|c|}
\hline Guns, Ammo (8) & 25 & 19 & 13 & $\mathbf{0}$ & $\mathbf{0}$ & $\mathbf{0}$ & $\mathbf{0}$ & $\mathbf{0}$ \\
\hline Machinery (222) & 25 & 8 & 5 & 1 & $\mathbf{0}$ & $\mathbf{0}$ & 4 & 2 \\
\hline BB only (14) & 86 & 14 & 50 & 2 & $\mathbf{0}$ & $\mathbf{0}$ & 29 & 3 \\
\hline Defense Prod and Serv (19) & 16 & 26 & $\mathbf{0}$ & $\mathbf{0}$ & $\mathbf{0}$ & $\mathbf{0}$ & 11 & 34 \\
\hline Autos (97) & 34 & 27 & 6 & 1 & $\mathbf{0}$ & $\mathbf{0}$ & 3 & 2 \\
\hline BB only (12) & 58 & 26 & 17 & 1 & $\mathbf{0}$ & $\mathbf{0}$ & 17 & 3 \\
\hline Aerospace (31) & 45 & 27 & 26 & 3 & 3 & $\mathbf{0}$ & 29 & 16 \\
\hline BB only (9) & 89 & 27 & 67 & 3 & 11 & $\mathbf{0}$ & 67 & 16 \\
\hline Pharma (587) & 11 & 6 & 3 & 2 & $\mathbf{0}$ & $\mathbf{0}$ & 1 & 1 \\
\hline BB only (18) & 67 & 11 & 50 & 3 & $\mathbf{0}$ & $\mathbf{0}$ & 6 & $\mathbf{0}$ \\
\hline Computres (41) & 34 & 13 & 17 & 5 & $\mathbf{0}$ & $\mathbf{0}$ & 2 & $\mathbf{0}$ \\
\hline BB only (17) & 35 & 13 & 24 & 4 & $\mathbf{0}$ & $\mathbf{0}$ & 6 & $\mathbf{0}$ \\
\hline Internet Mfgr (17) & 71 & 18 & 24 & 2 & $\mathbf{0}$ & $\mathbf{0}$ & 6 & 13 \\
\hline BB only (2) & 100 & 14 & 100 & 3 & $\mathbf{0}$ & $\mathbf{0}$ & 50 & 17 \\
\hline Software (138) & 43 & 2 & 15 & $\mathbf{0}$ & 1 & $\mathbf{0}$ & 8 & 1 \\
\hline BB only (30) & 40 & 2 & 27 & $\mathbf{0}$ & $\mathbf{0}$ & $\mathbf{0}$ & 23 & 1 \\
\hline Telecom (1552) & 8 & 13 & 2 & 58 & $\mathbf{0}$ & $\mathbf{0}$ & 1 & 1 \\
\hline BB only (49) & 33 & 2 & 16 & 77 & $\mathbf{0}$ & $\mathbf{0}$ & 14 & 1 \\
\hline
\end{tabular}




\begin{tabular}{|c|c|c|c|c|c|c|c|c|}
\hline Industry (N) & $\begin{array}{c}\text { Cruz } \\
\% \text { of firms }\end{array}$ & $\begin{array}{c}\text { Cruz } \\
\text { \% of Money }\end{array}$ & $\begin{array}{c}\text { Fiorina } \\
\text { \% of firms }\end{array}$ & $\begin{array}{c}\text { Fiorina } \\
\text { \% of Money }\end{array}$ & $\begin{array}{l}\text { Gilmore } \\
\% \text { of firms }\end{array}$ & $\begin{array}{l}\text { Gilmore } \\
\text { \% of Money }\end{array}$ & $\begin{array}{l}\text { Graham } \\
\% \text { of firms }\end{array}$ & $\begin{array}{l}\text { Graham } \\
\text { \% of Money }\end{array}$ \\
\hline Beverages (38) & 29 & 10 & 16 & 1 & $\mathbf{0}$ & $\mathbf{0}$ & 11 & 1 \\
\hline BB only (5) & 60 & 2 & 20 & $\mathbf{0}$ & $\mathbf{0}$ & $\mathbf{0}$ & 40 & 1 \\
\hline Health (29951) & 7 & 22 & 1 & 1 & $\mathbf{0}$ & $\mathbf{0}$ & $\mathbf{0}$ & 1 \\
\hline BB only (18) & 56 & 6 & 22 & 1 & $\mathbf{0}$ & $\mathbf{0}$ & $\mathbf{0}$ & $\mathbf{0}$ \\
\hline Health Insur. (23) & 70 & 13 & 26 & 2 & 4 & $\mathbf{0}$ & 17 & 4 \\
\hline BB only (10) & 100 & 11 & 40 & 2 & 10 & $\mathbf{0}$ & 40 & 4 \\
\hline Credit Reporting (10) & 70 & 3 & 30 & 2 & $\mathbf{0}$ & $\mathbf{0}$ & 20 & $\mathbf{0}$ \\
\hline BB only (2) & 100 & 1 & 100 & 2 & $\mathbf{0}$ & $\mathbf{0}$ & 50 & $\mathbf{0}$ \\
\hline Auto Dealers (3188) & 5 & 3 & 1 & $\mathbf{0}$ & $\mathbf{0}$ & $\mathbf{0}$ & $\mathbf{0}$ & $\mathbf{0}$ \\
\hline BB only (7) & 71 & $\mathbf{0}$ & 14 & $\mathbf{0}$ & $\mathbf{0}$ & $\mathbf{0}$ & 14 & $\mathbf{0}$ \\
\hline Transp, Trk, RR (1659) & 13 & 31 & 1 & $\mathbf{0}$ & $\mathbf{0}$ & $\mathbf{0}$ & $\mathbf{0}$ & 2 \\
\hline BB only (11) & 64 & 8 & 18 & $\mathbf{0}$ & $\mathbf{0}$ & $\mathbf{0}$ & 27 & 5 \\
\hline Airlines (14) & 71 & 42 & 43 & 4 & $\mathbf{0}$ & $\mathbf{0}$ & $\mathbf{0}$ & $\mathbf{0}$ \\
\hline BB only (4) & 100 & 45 & 100 & 4 & $\mathbf{0}$ & $\mathbf{0}$ & $\mathbf{0}$ & $\mathbf{0}$ \\
\hline Utilities (2582) & 10 & 8 & 1 & $\mathbf{0}$ & $\mathbf{0}$ & 1 & 1 & 4 \\
\hline BB only (19) & 95 & 2 & 42 & $\mathbf{0}$ & 11 & 1 & 37 & 3 \\
\hline Commun (14) & 7 & $\mathbf{0}$ & $\mathbf{0}$ & $\mathbf{0}$ & $\mathbf{0}$ & $\mathbf{0}$ & $\mathbf{0}$ & $\mathbf{0}$ \\
\hline
\end{tabular}




\begin{tabular}{|c|c|c|c|c|c|c|c|c|}
\hline BB only (5) & 20 & $\mathbf{0}$ & $\mathbf{0}$ & $\mathbf{0}$ & $\mathbf{0}$ & $\mathbf{0}$ & $\mathbf{0}$ & $\mathbf{0}$ \\
\hline $\begin{array}{l}\text { Mortg and Non-Bk Lending } \\
\text { (136) }\end{array}$ & 10 & $\mathbf{0}$ & 1 & $\mathbf{0}$ & $\mathbf{0}$ & $\mathbf{0}$ & 1 & 1 \\
\hline BB only (5) & 40 & $\mathbf{0}$ & 40 & $\mathbf{0}$ & $\mathbf{0}$ & $\mathbf{0}$ & $\mathbf{0}$ & $\mathbf{0}$ \\
\hline Real Estate (12451) & 6 & 11 & 1 & 3 & $\mathbf{0}$ & $\mathbf{0}$ & $\mathbf{0}$ & 1 \\
\hline BB only (36) & 6 & 1 & 8 & 2 & $\mathbf{0}$ & $\mathbf{0}$ & 8 & 1 \\
\hline Insurance (4927) & 7 & 17 & 1 & 2 & $\mathbf{0}$ & $\mathbf{0}$ & $\mathbf{0}$ & 1 \\
\hline BB only (35) & 86 & 10 & 43 & 1 & 3 & $\mathbf{0}$ & 17 & 1 \\
\hline Comm Banking (3971) & 7 & 18 & 2 & 1 & $\mathbf{0}$ & $\mathbf{0}$ & $\mathbf{0}$ & 1 \\
\hline BB only (18) & 67 & 3 & 61 & 1 & 6 & $\mathbf{0}$ & 33 & 1 \\
\hline Invest and Hedge Funds (285) & 9 & 35 & 4 & $\mathbf{0}$ & $\mathbf{0}$ & $\mathbf{0}$ & 2 & $\mathbf{0}$ \\
\hline BB only (47) & 9 & $\mathbf{0}$ & 4 & $\mathbf{0}$ & 2 & $\mathbf{0}$ & 6 & $\mathbf{0}$ \\
\hline Priv Equity (14880) & 5 & 8 & 2 & 5 & $\mathbf{0}$ & $\mathbf{0}$ & 1 & 2 \\
\hline BB only (38) & $\mathbf{0}$ & $\mathbf{0}$ & 3 & 52 & $\mathbf{0}$ & $\mathbf{0}$ & 8 & 16 \\
\hline Brokers, Mut Fd (43) & 23 & 5 & 26 & 1 & $\mathbf{0}$ & $\mathbf{0}$ & 9 & 2 \\
\hline BB only (6) & 17 & $\mathbf{0}$ & 67 & 1 & $\mathbf{0}$ & $\mathbf{0}$ & 33 & $\mathbf{0}$ \\
\hline Retailing (195) & 41 & 2 & 10 & 1 & 1 & $\mathbf{0}$ & 3 & $\mathbf{0}$ \\
\hline BB only (68) & 53 & 2 & 16 & $\mathbf{0}$ & $\mathbf{0}$ & $\mathbf{0}$ & 4 & $\mathbf{0}$ \\
\hline 100 Small Bus nec (512364) & 5 & 15 & 1 & 2 & $\mathbf{0}$ & $\mathbf{0}$ & $\mathbf{0}$ & 1 \\
\hline
\end{tabular}




\begin{tabular}{|c|c|c|c|c|c|c|c|c|}
\hline Industry (N) & Huckabee & Huckabee & Jindal & Jindal & Kasich & Kasich & Pataki & Pataki \\
\hline & $\%$ of firms & \% of Money & $\%$ of firms & \% of Money & $\%$ of firms & \% of Money & $\%$ of firms & \% of Money \\
\hline Mining (26) & $\mathbf{0}$ & $\mathbf{0}$ & 4 & 2 & 8 & $\mathbf{0}$ & $\mathbf{0}$ & $\mathbf{0}$ \\
\hline BB only (2) & $\mathbf{0}$ & $\mathbf{0}$ & 50 & 2 & $\mathbf{0}$ & $\mathbf{0}$ & $\mathbf{0}$ & $\mathbf{0}$ \\
\hline Coal Mining (147) & $\mathbf{0}$ & $\mathbf{0}$ & $\mathbf{0}$ & $\mathbf{0}$ & 6 & 31 & $\mathbf{0}$ & $\mathbf{0}$ \\
\hline
\end{tabular}




\begin{tabular}{|c|c|c|c|c|c|c|c|c|}
\hline BB only (2) & $\mathbf{0}$ & $\mathbf{0}$ & $\mathbf{0}$ & $\mathbf{0}$ & $\mathbf{0}$ & $\mathbf{0}$ & $\mathbf{0}$ & $\mathbf{0}$ \\
\hline Accounting (275) & 1 & $\mathbf{0}$ & $\mathbf{0}$ & $\mathbf{0}$ & 3 & 15 & $\mathbf{0}$ & $\mathbf{0}$ \\
\hline BB only (3) & 33 & $\mathbf{0}$ & $\mathbf{0}$ & $\mathbf{0}$ & 100 & 5 & 33 & $\mathbf{0}$ \\
\hline Casinos (19) & $\mathbf{0}$ & $\mathbf{0}$ & $\mathbf{0}$ & $\mathbf{0}$ & 5 & $\mathbf{0}$ & 5 & $\mathbf{0}$ \\
\hline BB only (9) & $\mathbf{0}$ & $\mathbf{0}$ & $\mathbf{0}$ & $\mathbf{0}$ & 11 & $\mathbf{0}$ & 11 & $\mathbf{0}$ \\
\hline Service General (2346) & 1 & $\mathbf{0}$ & $\mathbf{0}$ & 6 & 3 & 22 & $\mathbf{0}$ & $\mathbf{0}$ \\
\hline BB only (57) & 12 & $\mathbf{0}$ & 4 & 4 & 18 & 1 & 2 & $\mathbf{0}$ \\
\hline Residential (16) & $\mathbf{0}$ & $\mathbf{0}$ & $\mathbf{0}$ & $\mathbf{0}$ & 13 & 23 & $\mathbf{0}$ & $\mathbf{0}$ \\
\hline Heavy Constr. (5488) & $\mathbf{0}$ & 1 & $\mathbf{0}$ & $\mathbf{0}$ & 1 & 18 & $\mathbf{0}$ & 1 \\
\hline BB only (9) & 33 & $\mathbf{0}$ & $\mathbf{0}$ & $\mathbf{0}$ & 44 & $\mathbf{0}$ & $\mathbf{0}$ & $\mathbf{0}$ \\
\hline Waste Mgt. (8) & $\mathbf{0}$ & $\mathbf{0}$ & 13 & 2 & 13 & 16 & $\mathbf{0}$ & $\mathbf{0}$ \\
\hline BB only (2) & $\mathbf{0}$ & $\mathbf{0}$ & $\mathbf{0}$ & $\mathbf{0}$ & 50 & 22 & $\mathbf{0}$ & $\mathbf{0}$ \\
\hline Food (1668) & $\mathbf{0}$ & $\mathbf{0}$ & $\mathbf{0}$ & 2 & 2 & 9 & $\mathbf{0}$ & $\mathbf{0}$ \\
\hline BB only (34) & $\mathbf{0}$ & $\mathbf{0}$ & $\mathbf{0}$ & $\mathbf{0}$ & 21 & 2 & $\mathbf{0}$ & $\mathbf{0}$ \\
\hline Tobacco (15) & $\mathbf{0}$ & $\mathbf{0}$ & $\mathbf{0}$ & $\mathbf{0}$ & 13 & 11 & $\mathbf{0}$ & $\mathbf{0}$ \\
\hline BB only (3) & $\mathbf{0}$ & $\mathbf{0}$ & $\mathbf{0}$ & $\mathbf{0}$ & 33 & 8 & $\mathbf{0}$ & $\mathbf{0}$ \\
\hline Textiles (13) & $\mathbf{0}$ & $\mathbf{0}$ & 0 & $\mathbf{0}$ & 8 & 37 & $\mathbf{0}$ & $\mathbf{0}$ \\
\hline Apparel (23) & 4 & 1 & 0 & $\mathbf{0}$ & 4 & 46 & $\mathbf{0}$ & $\mathbf{0}$ \\
\hline BB only (5) & $\mathbf{0}$ & $\mathbf{0}$ & $\mathbf{0}$ & $\mathbf{0}$ & 20 & 54 & $\mathbf{0}$ & $\mathbf{0}$ \\
\hline
\end{tabular}




\begin{tabular}{|c|c|c|c|c|c|c|c|c|}
\hline Agribusiness (120) & 1 & $\mathbf{0}$ & $\mathbf{0}$ & $\mathbf{0}$ & $\mathbf{0}$ & $\mathbf{0}$ & $\mathbf{0}$ & $\mathbf{0}$ \\
\hline Paper (300) & 1 & $\mathbf{0}$ & $\mathbf{0}$ & $\mathbf{0}$ & 4 & 2 & $\mathbf{0}$ & $\mathbf{0}$ \\
\hline BB only (8) & 13 & $\mathbf{0}$ & $\mathbf{0}$ & $\mathbf{0}$ & 50 & 1 & $\mathbf{0}$ & $\mathbf{0}$ \\
\hline Printing and Pub (14) & 7 & 5 & $\mathbf{0}$ & $\mathbf{0}$ & 7 & 2 & $\mathbf{0}$ & $\mathbf{0}$ \\
\hline BB only (1) & $\mathbf{0}$ & $\mathbf{0}$ & $\mathbf{0}$ & $\mathbf{0}$ & $\mathbf{0}$ & $\mathbf{0}$ & $\mathbf{0}$ & $\mathbf{0}$ \\
\hline Chemical (695) & $\mathbf{0}$ & $\mathbf{0}$ & 1 & 5 & 5 & 21 & $\mathbf{0}$ & $\mathbf{0}$ \\
\hline BB only (16) & 13 & $\mathbf{0}$ & $\mathbf{0}$ & $\mathbf{0}$ & 31 & 4 & $\mathbf{0}$ & $\mathbf{0}$ \\
\hline Oil (3987) & 1 & 4 & $\mathbf{0}$ & 1 & 3 & 5 & $\mathbf{0}$ & 1 \\
\hline BB only (62) & 8 & 5 & 3 & $\mathbf{0}$ & 29 & 2 & 2 & $\mathbf{0}$ \\
\hline Rubber (318) & 1 & 2 & $\mathbf{0}$ & 1 & 4 & 15 & $\mathbf{0}$ & $\mathbf{0}$ \\
\hline BB only (1) & 100 & 2 & $\mathbf{0}$ & $\mathbf{0}$ & 100 & 45 & $\mathbf{0}$ & $\mathbf{0}$ \\
\hline
\end{tabular}

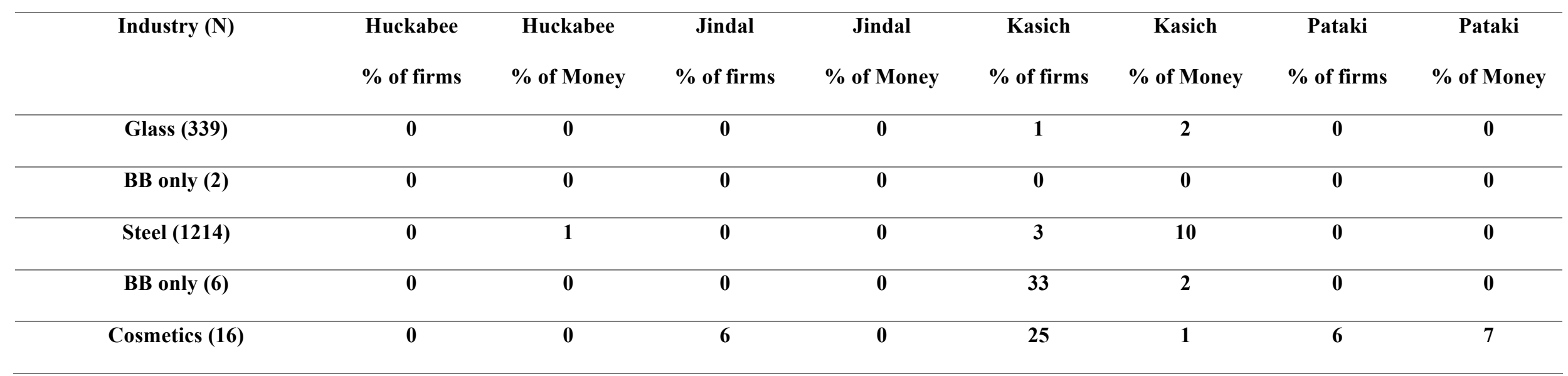




\begin{tabular}{|c|c|c|c|c|c|c|c|c|}
\hline BB only (9) & $\mathbf{0}$ & $\mathbf{0}$ & 11 & $\mathbf{0}$ & 33 & 1 & 11 & 8 \\
\hline Altern Energy (22) & $\mathbf{0}$ & $\mathbf{0}$ & $\mathbf{0}$ & $\mathbf{0}$ & $\mathbf{0}$ & $\mathbf{0}$ & $\mathbf{0}$ & $\mathbf{0}$ \\
\hline Electronics (121) & 2 & 2 & 2 & 1 & 15 & 5 & $\mathbf{0}$ & $\mathbf{0}$ \\
\hline BB only (13) & 15 & 1 & 8 & $\mathbf{0}$ & 62 & 8 & $\mathbf{0}$ & $\mathbf{0}$ \\
\hline Guns, Ammo (8) & $\mathbf{0}$ & $\mathbf{0}$ & $\mathbf{0}$ & $\mathbf{0}$ & $\mathbf{0}$ & $\mathbf{0}$ & $\mathbf{0}$ & $\mathbf{0}$ \\
\hline Machinery (222) & 2 & $\mathbf{0}$ & $\mathbf{0}$ & $\mathbf{0}$ & 9 & 50 & $\mathbf{0}$ & $\mathbf{0}$ \\
\hline BB only (14) & 29 & $\mathbf{0}$ & 7 & 1 & 50 & 19 & $\mathbf{0}$ & $\mathbf{0}$ \\
\hline Defense Prod and Serv (19) & 5 & 6 & 5 & 6 & 5 & 1 & $\mathbf{0}$ & $\mathbf{0}$ \\
\hline Autos (97) & 2 & 3 & $\mathbf{0}$ & $\mathbf{0}$ & 5 & 5 & 1 & 1 \\
\hline BB only (12) & $\mathbf{0}$ & $\mathbf{0}$ & $\mathbf{0}$ & $\mathbf{0}$ & 33 & 8 & $\mathbf{0}$ & $\mathbf{0}$ \\
\hline Aerospace (31) & 19 & 1 & 6 & $\mathbf{0}$ & 32 & 7 & $\mathbf{0}$ & $\mathbf{0}$ \\
\hline BB only (9) & 56 & $\mathbf{0}$ & 22 & $\mathbf{0}$ & 78 & 7 & $\mathbf{0}$ & $\mathbf{0}$ \\
\hline Pharma (587) & 1 & $\mathbf{0}$ & $\mathbf{0}$ & $\mathbf{0}$ & 5 & 11 & $\mathbf{0}$ & 1 \\
\hline BB only (18) & 11 & $\mathbf{0}$ & $\mathbf{0}$ & $\mathbf{0}$ & 67 & 28 & $\mathbf{0}$ & $\mathbf{0}$ \\
\hline Computres (41) & 5 & $\mathbf{0}$ & 2 & 1 & 22 & 2 & $\mathbf{0}$ & $\mathbf{0}$ \\
\hline BB only (17) & 12 & $\mathbf{0}$ & 6 & 1 & 18 & 1 & $\mathbf{0}$ & $\mathbf{0}$ \\
\hline Internet Mfgr (17) & 6 & $\mathbf{0}$ & $\mathbf{0}$ & $\mathbf{0}$ & 35 & 29 & $\mathbf{0}$ & $\mathbf{0}$ \\
\hline BB only (2) & $\mathbf{0}$ & $\mathbf{0}$ & $\mathbf{0}$ & $\mathbf{0}$ & 100 & 34 & $\mathbf{0}$ & $\mathbf{0}$ \\
\hline Software (138) & 4 & $\mathbf{0}$ & 1 & $\mathbf{0}$ & 19 & 2 & 1 & $\mathbf{0}$ \\
\hline
\end{tabular}




\begin{tabular}{|c|c|c|c|c|c|c|c|c|}
\hline BB only (30) & 13 & $\mathbf{0}$ & 3 & $\mathbf{0}$ & 27 & $\mathbf{0}$ & $\mathbf{0}$ & $\mathbf{0}$ \\
\hline Telecom (1552) & 1 & $\mathbf{0}$ & $\mathbf{0}$ & $\mathbf{0}$ & 3 & 4 & $\mathbf{0}$ & $\mathbf{0}$ \\
\hline BB only (49) & 6 & $\mathbf{0}$ & 2 & $\mathbf{0}$ & 29 & 3 & 4 & $\mathbf{0}$ \\
\hline Beverages (38) & 3 & $\mathbf{0}$ & 3 & $\mathbf{0}$ & 11 & 2 & $\mathbf{0}$ & $\mathbf{0}$ \\
\hline BB only (5) & 20 & 1 & $\mathbf{0}$ & $\mathbf{0}$ & 40 & 2 & $\mathbf{0}$ & $\mathbf{0}$ \\
\hline Health (29951) & $\mathbf{0}$ & $\mathbf{0}$ & $\mathbf{0}$ & 2 & 1 & 4 & $\mathbf{0}$ & 1 \\
\hline BB only (18) & 11 & $\mathbf{0}$ & 6 & 23 & 39 & 3 & $\mathbf{0}$ & $\mathbf{0}$ \\
\hline Health Insur. (23) & 13 & $\mathbf{0}$ & 9 & 1 & 39 & 8 & 9 & 4 \\
\hline BB only (10) & 30 & $\mathbf{0}$ & 20 & 1 & 80 & 5 & 20 & 5 \\
\hline
\end{tabular}

\begin{tabular}{|c|c|c|c|c|c|c|c|c|}
\hline Industry (N) & Huckabee & Huckabee & Jindal & Jindal & Kasich & Kasich & Pataki & Pataki \\
\hline & $\%$ of firms & \% of Money & $\%$ of firms & \% of Money & $\%$ of firms & \% of Money & $\%$ of firms & \% of Money \\
\hline Credit Reporting (10) & $\mathbf{0}$ & $\mathbf{0}$ & $\mathbf{0}$ & $\mathbf{0}$ & 50 & 15 & $\mathbf{0}$ & $\mathbf{0}$ \\
\hline BB only (2) & $\mathbf{0}$ & $\mathbf{0}$ & $\mathbf{0}$ & $\mathbf{0}$ & 100 & 1 & $\mathbf{0}$ & $\mathbf{0}$ \\
\hline Auto Dealers (3188) & $\mathbf{0}$ & $\mathbf{0}$ & $\mathbf{0}$ & 1 & 1 & 2 & $\mathbf{0}$ & $\mathbf{0}$ \\
\hline BB only (7) & $\mathbf{0}$ & $\mathbf{0}$ & $\mathbf{0}$ & $\mathbf{0}$ & 14 & $\mathbf{0}$ & $\mathbf{0}$ & $\mathbf{0}$ \\
\hline
\end{tabular}




\begin{tabular}{|c|c|c|c|c|c|c|c|c|}
\hline Transp, Trk, RR (1659) & 1 & 1 & $\mathbf{0}$ & $\mathbf{0}$ & 1 & 2 & $\mathbf{0}$ & $\mathbf{0}$ \\
\hline BB only (11) & 18 & 1 & $\mathbf{0}$ & $\mathbf{0}$ & 36 & 2 & $\mathbf{0}$ & $\mathbf{0}$ \\
\hline Airlines (14) & 21 & 2 & $\mathbf{0}$ & $\mathbf{0}$ & 36 & 4 & $\mathbf{0}$ & $\mathbf{0}$ \\
\hline BB only (4) & 75 & 2 & $\mathbf{0}$ & $\mathbf{0}$ & 100 & 3 & $\mathbf{0}$ & $\mathbf{0}$ \\
\hline Utilities (2582) & $\mathbf{0}$ & $\mathbf{0}$ & $\mathbf{0}$ & $\mathbf{0}$ & 1 & 7 & $\mathbf{0}$ & $\mathbf{0}$ \\
\hline BB only (19) & 11 & $\mathbf{0}$ & 21 & $\mathbf{0}$ & 58 & 8 & 5 & $\mathbf{0}$ \\
\hline Commun (14) & $\mathbf{0}$ & $\mathbf{0}$ & $\mathbf{0}$ & $\mathbf{0}$ & 29 & 57 & 7 & $\mathbf{0}$ \\
\hline BB only (5) & $\mathbf{0}$ & $\mathbf{0}$ & $\mathbf{0}$ & $\mathbf{0}$ & 60 & 58 & 20 & $\mathbf{0}$ \\
\hline $\begin{array}{c}\text { Mortg and Non-Bk Lending } \\
\text { (136) }\end{array}$ & $\mathbf{0}$ & $\mathbf{0}$ & $\mathbf{0}$ & $\mathbf{0}$ & 5 & 29 & $\mathbf{0}$ & $\mathbf{0}$ \\
\hline BB only (5) & $\mathbf{0}$ & $\mathbf{0}$ & $\mathbf{0}$ & $\mathbf{0}$ & 40 & 36 & $\mathbf{0}$ & $\mathbf{0}$ \\
\hline Real Estate (12451) & 1 & 1 & $\mathbf{0}$ & 1 & 2 & 10 & $\mathbf{0}$ & 1 \\
\hline BB only (36) & 3 & $\mathbf{0}$ & $\mathbf{0}$ & $\mathbf{0}$ & 17 & 32 & 3 & 3 \\
\hline Insurance (4927) & 1 & 1 & $\mathbf{0}$ & 4 & 2 & 16 & $\mathbf{0}$ & $\mathbf{0}$ \\
\hline BB only (35) & 23 & 1 & 6 & 8 & 54 & 4 & 3 & $\mathbf{0}$ \\
\hline Comm Banking (3971) & 1 & $\mathbf{0}$ & $\mathbf{0}$ & $\mathbf{0}$ & 3 & 7 & $\mathbf{0}$ & $\mathbf{0}$ \\
\hline BB only (18) & 22 & $\mathbf{0}$ & 11 & $\mathbf{0}$ & 61 & 7 & 11 & $\mathbf{0}$ \\
\hline Invest and Hedge Funds (285) & 1 & $\mathbf{0}$ & 1 & 1 & 10 & 15 & $\mathbf{0}$ & $\mathbf{0}$ \\
\hline BB only (47) & 2 & $\mathbf{0}$ & $\mathbf{0}$ & $\mathbf{0}$ & 15 & 24 & 2 & $\mathbf{0}$ \\
\hline Priv Equity (14880) & $\mathbf{0}$ & $\mathbf{0}$ & $\mathbf{0}$ & 1 & 3 & 17 & $\mathbf{0}$ & $\mathbf{0}$ \\
\hline
\end{tabular}




\begin{tabular}{|c|c|c|c|c|c|c|c|c|}
\hline BB only (38) & $\mathbf{0}$ & $\mathbf{0}$ & $\mathbf{0}$ & $\mathbf{0}$ & 5 & 7 & $\mathbf{0}$ & $\mathbf{0}$ \\
\hline Brokers, Mut Fd (43) & 2 & $\mathbf{0}$ & 2 & $\mathbf{0}$ & 21 & 13 & 2 & 1 \\
\hline BB only (6) & $\mathbf{0}$ & $\mathbf{0}$ & 17 & $\mathbf{0}$ & 17 & $\mathbf{0}$ & 17 & 2 \\
\hline Retailing (195) & 2 & $\mathbf{0}$ & 3 & 1 & 18 & 58 & 1 & $\mathbf{0}$ \\
\hline BB only (68) & 4 & $\mathbf{0}$ & 7 & 1 & 35 & 62 & $\mathbf{0}$ & $\mathbf{0}$ \\
\hline 100 Small Bus nec (512364) & $\mathbf{0}$ & 3 & $\mathbf{0}$ & 1 & 1 & 12 & $\mathbf{0}$ & $\mathbf{0}$ \\
\hline
\end{tabular}

\begin{tabular}{|c|c|c|c|c|c|c|c|c|c|c|}
\hline Industry (N) & Paul & Paul & Perry & Perry & Rubio & Rubio & Santorum & Santorum & Walker & Walker \\
\hline & $\begin{array}{l}\% \text { of } \\
\text { firms }\end{array}$ & $\begin{array}{c}\text { \% of } \\
\text { Money }\end{array}$ & $\begin{array}{l}\% \text { of } \\
\text { firms }\end{array}$ & $\begin{array}{c}\text { \% of } \\
\text { Money }\end{array}$ & $\%$ of firms & \% of Money & $\%$ of firms & \% of Money & $\begin{array}{l}\% \text { of } \\
\text { firms }\end{array}$ & \% of Money \\
\hline Mining (26) & 8 & 1 & $\mathbf{0}$ & $\mathbf{0}$ & 12 & 2 & $\mathbf{0}$ & $\mathbf{0}$ & $\mathbf{0}$ & $\mathbf{0}$ \\
\hline BB only (2) & 50 & $\mathbf{0}$ & $\mathbf{0}$ & $\mathbf{0}$ & 50 & 1 & 50 & $\mathbf{0}$ & $\mathbf{0}$ & $\mathbf{0}$ \\
\hline Coal Mining (147) & 5 & $\mathbf{0}$ & 1 & 1 & 7 & 46 & 1 & $\mathbf{0}$ & 1 & 4 \\
\hline BB only (2) & $\mathbf{0}$ & $\mathbf{0}$ & $\mathbf{0}$ & $\mathbf{0}$ & 100 & 100 & 100 & $\mathbf{0}$ & $\mathbf{0}$ & $\mathbf{0}$ \\
\hline Accounting (275) & 1 & $\mathbf{0}$ & $\mathbf{0}$ & $\mathbf{0}$ & 4 & 10 & $\mathbf{0}$ & $\mathbf{0}$ & 2 & 3 \\
\hline BB only (3) & 67 & $\mathbf{0}$ & 33 & $\mathbf{0}$ & 100 & 10 & 100 & $\mathbf{0}$ & 67 & 2 \\
\hline BB only (9) & 22 & $\mathbf{0}$ & $\mathbf{0}$ & $\mathbf{0}$ & 22 & 1 & 89 & $\mathbf{0}$ & 11 & 3 \\
\hline Service General (2346) & 2 & 2 & $\mathbf{0}$ & $\mathbf{0}$ & 5 & 4 & $\mathbf{0}$ & $\mathbf{0}$ & 1 & 26 \\
\hline BB only (57) & 12 & 1 & 7 & $\mathbf{0}$ & 32 & 1 & 49 & $\mathbf{0}$ & 19 & 35 \\
\hline
\end{tabular}




\begin{tabular}{|c|c|c|c|c|c|c|c|c|c|c|}
\hline Residential (16) & 25 & $\mathbf{0}$ & 6 & 1 & 50 & 3 & $\mathbf{0}$ & $\mathbf{0}$ & 6 & 1 \\
\hline Heavy Constr. (5488) & 1 & 1 & $\mathbf{0}$ & 2 & 3 & 7 & $\mathbf{0}$ & $\mathbf{0}$ & 1 & 2 \\
\hline Waste Mgt. (8) & 13 & 2 & $\mathbf{0}$ & $\mathbf{0}$ & 13 & 2 & $\mathbf{0}$ & $\mathbf{0}$ & $\mathbf{0}$ & $\mathbf{0}$ \\
\hline BB only (2) & 50 & 2 & $\mathbf{0}$ & $\mathbf{0}$ & 50 & 3 & 100 & $\mathbf{0}$ & $\mathbf{0}$ & $\mathbf{0}$ \\
\hline Food (1668) & 1 & $\mathbf{0}$ & $\mathbf{0}$ & $\mathbf{0}$ & 5 & 12 & $\mathbf{0}$ & $\mathbf{0}$ & 1 & 5 \\
\hline BB only (34) & 18 & 1 & $\mathbf{0}$ & $\mathbf{0}$ & 32 & 7 & 59 & 1 & 12 & 6 \\
\hline Tobacco (15) & $\mathbf{0}$ & $\mathbf{0}$ & $\mathbf{0}$ & $\mathbf{0}$ & 27 & 20 & $\mathbf{0}$ & $\mathbf{0}$ & 7 & 11 \\
\hline BB only (3) & $\mathbf{0}$ & $\mathbf{0}$ & $\mathbf{0}$ & $\mathbf{0}$ & 100 & 24 & 100 & $\mathbf{0}$ & 33 & 13 \\
\hline Textiles (13) & $\mathbf{0}$ & $\mathbf{0}$ & $\mathbf{0}$ & $\mathbf{0}$ & $\mathbf{0}$ & $\mathbf{0}$ & $\mathbf{0}$ & $\mathbf{0}$ & $\mathbf{0}$ & $\mathbf{0}$ \\
\hline Apparel (23) & 9 & $\mathbf{0}$ & $\mathbf{0}$ & $\mathbf{0}$ & 26 & 5 & $\mathbf{0}$ & $\mathbf{0}$ & $\mathbf{0}$ & $\mathbf{0}$ \\
\hline BB only (5) & 20 & $\mathbf{0}$ & $\mathbf{0}$ & $\mathbf{0}$ & 40 & 1 & 60 & $\mathbf{0}$ & $\mathbf{0}$ & $\mathbf{0}$ \\
\hline Agribusiness (120) & $\mathbf{0}$ & $\mathbf{0}$ & $\mathbf{0}$ & $\mathbf{0}$ & 10 & 61 & $\mathbf{0}$ & $\mathbf{0}$ & 2 & 4 \\
\hline Paper (300) & 4 & $\mathbf{0}$ & $\mathbf{0}$ & $\mathbf{0}$ & 6 & 43 & $\mathbf{0}$ & $\mathbf{0}$ & 3 & 1 \\
\hline BB only (8) & 38 & $\mathbf{0}$ & $\mathbf{0}$ & $\mathbf{0}$ & 38 & 60 & 63 & $\mathbf{0}$ & $\mathbf{0}$ & $\mathbf{0}$ \\
\hline Printing and Pub (14) & 7 & $\mathbf{0}$ & $\mathbf{0}$ & $\mathbf{0}$ & 29 & 12 & 7 & $\mathbf{0}$ & 7 & $\mathbf{0}$ \\
\hline BB only (1) & 100 & $\mathbf{0}$ & $\mathbf{0}$ & $\mathbf{0}$ & 100 & 1 & 100 & $\mathbf{0}$ & $\mathbf{0}$ & $\mathbf{0}$ \\
\hline
\end{tabular}




\begin{tabular}{|c|c|c|c|c|c|c|c|c|c|c|}
\hline Oil (3987) & 2 & 1 & 1 & 12 & 6 & 7 & $\mathbf{0}$ & 0 & 2 & 3 \\
\hline BB only (62) & 24 & $\mathbf{0}$ & 15 & 16 & 52 & 8 & 73 & $\mathbf{0}$ & 23 & 2 \\
\hline
\end{tabular}

\begin{tabular}{|c|c|c|c|c|c|c|c|c|c|c|}
\hline Industry (N) & Paul & Paul & Perry & Perry & Rubio & Rubio & Santorum & Santorum & Walker & Walker \\
\hline & $\begin{array}{l}\% \text { of } \\
\text { firms }\end{array}$ & $\begin{array}{c}\text { \% of } \\
\text { Money }\end{array}$ & $\begin{array}{l}\% \text { of } \\
\text { firms }\end{array}$ & $\begin{array}{c}\% \text { of } \\
\text { Money }\end{array}$ & $\%$ of firms & \% of Money & $\%$ of firms & \% of Money & $\begin{array}{l}\% \text { of } \\
\text { firms }\end{array}$ & \% of Money \\
\hline Rubber (318) & 2 & 3 & $\mathbf{0}$ & $\mathbf{0}$ & 5 & 11 & $\mathbf{0}$ & $\mathbf{0}$ & 1 & 1 \\
\hline BB only (1) & 100 & 3 & $\mathbf{0}$ & $\mathbf{0}$ & 100 & 11 & 100 & $\mathbf{0}$ & 100 & 11 \\
\hline Glass (339) & 2 & 2 & $\mathbf{0}$ & $\mathbf{0}$ & 4 & 5 & $\mathbf{0}$ & $\mathbf{0}$ & 1 & $\mathbf{0}$ \\
\hline BB only (2) & 50 & $\mathbf{0}$ & $\mathbf{0}$ & $\mathbf{0}$ & 50 & $\mathbf{0}$ & 50 & $\mathbf{0}$ & $\mathbf{0}$ & $\mathbf{0}$ \\
\hline Steel (1214) & 2 & 3 & $\mathbf{0}$ & 1 & 4 & 11 & $\mathbf{0}$ & $\mathbf{0}$ & 1 & 4 \\
\hline BB only (6) & 33 & 5 & $\mathbf{0}$ & $\mathbf{0}$ & 33 & 11 & 67 & $\mathbf{0}$ & 17 & 1 \\
\hline BB only (9) & 22 & $\mathbf{0}$ & $\mathbf{0}$ & $\mathbf{0}$ & 22 & 30 & 56 & $\mathbf{0}$ & 11 & $\mathbf{0}$ \\
\hline Altern Energy (22) & 9 & 31 & $\mathbf{0}$ & $\mathbf{0}$ & 5 & 17 & $\mathbf{0}$ & $\mathbf{0}$ & 5 & 2 \\
\hline Electronics (121) & 13 & 3 & 2 & $\mathbf{0}$ & 21 & 20 & 2 & $\mathbf{0}$ & 4 & 5 \\
\hline BB only (13) & 46 & 7 & 8 & $\mathbf{0}$ & 31 & 7 & 85 & 1 & 15 & 1 \\
\hline Guns, Ammo (8) & 13 & $\mathbf{0}$ & 13 & 3 & 38 & 31 & $\mathbf{0}$ & $\mathbf{0}$ & 25 & 14 \\
\hline
\end{tabular}




\begin{tabular}{|c|c|c|c|c|c|c|c|c|c|c|}
\hline Machinery (222) & 8 & 2 & 1 & $\mathbf{0}$ & 11 & 3 & $\mathbf{0}$ & $\mathbf{0}$ & 6 & 5 \\
\hline BB only (14) & 71 & 4 & $\mathbf{0}$ & $\mathbf{0}$ & 50 & 5 & 93 & $\mathbf{0}$ & 50 & 3 \\
\hline Autos (97) & 9 & 4 & $\mathbf{0}$ & $\mathbf{0}$ & 9 & 5 & 1 & 1 & 3 & 1 \\
\hline BB only (12) & 33 & 4 & $\mathbf{0}$ & $\mathbf{0}$ & 33 & 5 & 67 & $\mathbf{0}$ & 8 & $\mathbf{0}$ \\
\hline Aerospace (31) & 35 & 4 & $\mathbf{0}$ & $\mathbf{0}$ & 39 & 10 & 6 & $\mathbf{0}$ & 19 & 3 \\
\hline BB only (9) & 89 & 4 & $\mathbf{0}$ & $\mathbf{0}$ & 78 & 9 & 89 & $\mathbf{0}$ & 56 & 3 \\
\hline Pharma (587) & 3 & 5 & $\mathbf{0}$ & $\mathbf{0}$ & 9 & 7 & $\mathbf{0}$ & $\mathbf{0}$ & 2 & 10 \\
\hline BB only (18) & 39 & 6 & 11 & $\mathbf{0}$ & 61 & 9 & 83 & $\mathbf{0}$ & 28 & 4 \\
\hline Computres (41) & 15 & 3 & 2 & 1 & 24 & 6 & 2 & $\mathbf{0}$ & 20 & 9 \\
\hline BB only (17) & 24 & 2 & 6 & 1 & 35 & 6 & 41 & $\mathbf{0}$ & 29 & 9 \\
\hline Internet Mfgr (17) & 47 & 5 & 6 & 3 & 41 & 5 & $\mathbf{0}$ & $\mathbf{0}$ & 18 & 2 \\
\hline BB only (2) & 100 & 4 & 50 & 4 & 100 & 7 & 100 & $\mathbf{0}$ & 50 & $\mathbf{0}$ \\
\hline Software (138) & 23 & 1 & $\mathbf{0}$ & $\mathbf{0}$ & 31 & 83 & 1 & $\mathbf{0}$ & 9 & $\mathbf{0}$ \\
\hline BB only (30) & 37 & 1 & $\mathbf{0}$ & $\mathbf{0}$ & 43 & 91 & 50 & $\mathbf{0}$ & 23 & $\mathbf{0}$ \\
\hline Telecom (1552) & 2 & 2 & $\mathbf{0}$ & 2 & 5 & 3 & $\mathbf{0}$ & $\mathbf{0}$ & 1 & 4 \\
\hline BB only (49) & 22 & 1 & $\mathbf{0}$ & $\mathbf{0}$ & 29 & 2 & 39 & $\mathbf{0}$ & 16 & 3 \\
\hline
\end{tabular}




\begin{tabular}{|c|c|c|c|c|c|c|c|c|c|c|}
\hline Health (29951) & 1 & 2 & $\mathbf{0}$ & 1 & 3 & 7 & $\mathbf{0}$ & $\mathbf{0}$ & 1 & 1 \\
\hline BB only (18) & 11 & 1 & $\mathbf{0}$ & $\mathbf{0}$ & 50 & 8 & 61 & $\mathbf{0}$ & $\mathbf{0}$ & $\mathbf{0}$ \\
\hline
\end{tabular}

\begin{tabular}{|c|c|c|c|c|c|c|c|c|c|c|}
\hline Industry (N) & Paul & Paul & Perry & Perry & Rubio & Rubio & Santorum & Santorum & Walker & Walker \\
\hline & $\begin{array}{l}\% \text { of } \\
\text { firms }\end{array}$ & $\begin{array}{c}\text { \% of } \\
\text { Money }\end{array}$ & $\begin{array}{l}\% \text { of } \\
\text { firms }\end{array}$ & $\begin{array}{c}\text { \% of } \\
\text { Money }\end{array}$ & $\%$ of firms & \% of Money & $\%$ of firms & \% of Money & $\begin{array}{l}\% \text { of } \\
\text { firms }\end{array}$ & \% of Money \\
\hline Health Insur. (23) & 39 & 1 & 9 & $\mathbf{0}$ & 57 & 7 & 9 & 1 & 22 & 1 \\
\hline BB only (10) & 70 & 2 & 20 & $\mathbf{0}$ & 80 & 8 & 100 & 2 & 30 & 1 \\
\hline Credit Reporting (10) & 40 & 1 & $\mathbf{0}$ & $\mathbf{0}$ & 50 & 4 & $\mathbf{0}$ & $\mathbf{0}$ & 20 & 1 \\
\hline BB only (2) & 100 & $\mathbf{0}$ & $\mathbf{0}$ & $\mathbf{0}$ & 100 & 3 & 100 & $\mathbf{0}$ & 50 & $\mathbf{0}$ \\
\hline Auto Dealers (3188) & 1 & 1 & $\mathbf{0}$ & 1 & 3 & 84 & $\mathbf{0}$ & $\mathbf{0}$ & 1 & $\mathbf{0}$ \\
\hline BB only (7) & 14 & $\mathbf{0}$ & 14 & 1 & 43 & 99 & 71 & $\mathbf{0}$ & $\mathbf{0}$ & $\mathbf{0}$ \\
\hline BB only (11) & 27 & 1 & $\mathbf{0}$ & $\mathbf{0}$ & 45 & 7 & 64 & $\mathbf{0}$ & 18 & -1 \\
\hline Airlines (14) & 36 & 4 & $\mathbf{0}$ & $\mathbf{0}$ & 43 & 11 & 7 & 1 & 29 & 2 \\
\hline BB only (4) & 100 & 5 & $\mathbf{0}$ & $\mathbf{0}$ & 100 & 12 & 100 & 1 & 100 & 2 \\
\hline Utilities (2582) & 1 & 1 & $\mathbf{0}$ & 1 & 3 & 9 & $\mathbf{0}$ & $\mathbf{0}$ & 1 & 2 \\
\hline BB only (19) & 32 & $\mathbf{0}$ & 5 & $\mathbf{0}$ & 79 & 9 & 95 & $\mathbf{0}$ & 26 & 1 \\
\hline Commun (14) & 7 & $\mathbf{0}$ & $\mathbf{0}$ & $\mathbf{0}$ & 36 & 1 & $\mathbf{0}$ & $\mathbf{0}$ & $\mathbf{0}$ & $\mathbf{0}$ \\
\hline
\end{tabular}




\begin{tabular}{|c|c|c|c|c|c|c|c|c|c|c|}
\hline BB only (5) & $\mathbf{0}$ & $\mathbf{0}$ & $\mathbf{0}$ & $\mathbf{0}$ & 60 & 1 & 40 & $\mathbf{0}$ & $\mathbf{0}$ & $\mathbf{0}$ \\
\hline $\begin{array}{c}\text { Mortg and Non-Bk Lending } \\
\text { (136) }\end{array}$ & 2 & $\mathbf{0}$ & 1 & $\mathbf{0}$ & 10 & 1 & $\mathbf{0}$ & $\mathbf{0}$ & 4 & $\mathbf{0}$ \\
\hline BB only (5) & $\mathbf{0}$ & $\mathbf{0}$ & $\mathbf{0}$ & $\mathbf{0}$ & 60 & $\mathbf{0}$ & 100 & $\mathbf{0}$ & 20 & $\mathbf{0}$ \\
\hline Real Estate (12451) & 1 & 1 & $\mathbf{0}$ & 1 & 4 & 14 & $\mathbf{0}$ & 1 & 1 & 2 \\
\hline BB only (36) & 3 & $\mathbf{0}$ & 6 & $\mathbf{0}$ & 17 & 34 & 22 & $\mathbf{0}$ & 3 & 1 \\
\hline Insurance (4927) & 1 & 2 & $\mathbf{0}$ & 1 & 4 & 10 & $\mathbf{0}$ & $\mathbf{0}$ & 1 & 3 \\
\hline BB only (35) & 51 & 2 & 3 & $\mathbf{0}$ & 77 & 11 & 91 & $\mathbf{0}$ & 29 & 1 \\
\hline Comm Banking (3971) & 2 & 3 & $\mathbf{0}$ & 1 & 5 & 16 & $\mathbf{0}$ & $\mathbf{0}$ & 1 & 1 \\
\hline Invest and Hedge Funds (285) & 2 & $\mathbf{0}$ & 1 & $\mathbf{0}$ & 15 & 27 & 1 & $\mathbf{0}$ & 5 & 1 \\
\hline BB only (47) & $\mathbf{0}$ & $\mathbf{0}$ & 2 & $\mathbf{0}$ & 19 & 44 & 17 & $\mathbf{0}$ & 15 & 1 \\
\hline Priv Equity (14880) & 1 & 12 & $\mathbf{0}$ & 1 & 6 & 9 & $\mathbf{0}$ & 1 & 1 & 2 \\
\hline BB only (38) & $\mathbf{0}$ & $\mathbf{0}$ & $\mathbf{0}$ & $\mathbf{0}$ & 5 & 2 & 21 & $\mathbf{0}$ & 3 & $\mathbf{0}$ \\
\hline Brokers, Mut Fd (43) & 9 & $\mathbf{0}$ & 5 & $\mathbf{0}$ & 23 & 17 & $\mathbf{0}$ & $\mathbf{0}$ & 7 & 2 \\
\hline BB only (6) & 17 & $\mathbf{0}$ & $\mathbf{0}$ & $\mathbf{0}$ & 50 & 1 & 33 & $\mathbf{0}$ & 33 & 3 \\
\hline Retailing (195) & 15 & 4 & 1 & $\mathbf{0}$ & 26 & 5 & 1 & $\mathbf{0}$ & 9 & 2 \\
\hline BB only (68) & 28 & 5 & $\mathbf{0}$ & $\mathbf{0}$ & 38 & 5 & 62 & $\mathbf{0}$ & 21 & 1 \\
\hline
\end{tabular}


Table 5

Industrial Structure of the Democratic Race

Numbers Are Rounded

\begin{tabular}{|c|c|c|c|c|c|c|c|c|}
\hline Industry (N) & $\begin{array}{l}\text { Clinton } \\
\% \text { of firms }\end{array}$ & $\begin{array}{l}\text { Clinton } \\
\% \text { of Money }\end{array}$ & $\begin{array}{l}\text { Sanders } \\
\% \text { of firms }\end{array}$ & $\begin{array}{l}\text { Sanders } \\
\% \text { of Money }\end{array}$ & $\begin{array}{l}\text { O'Malley } \\
\% \text { of firms }\end{array}$ & $\begin{array}{l}\text { O'Malley } \\
\text { \% of Money }\end{array}$ & $\begin{array}{c}\text { Webb } \\
\% \text { of firms }\end{array}$ & $\begin{array}{c}\text { Webb } \\
\% \text { of Money }\end{array}$ \\
\hline Mining (26) & 31 & 79 & 27 & 20 & 0 & 0 & 4 & 1 \\
\hline BB only (2) & 100 & 84 & 50 & 16 & 0 & 0 & 0 & 0 \\
\hline Coal Mining (147) & 6 & 68 & 5 & 18 & 1 & 14 & 0 & 0 \\
\hline BB only (2) & 0 & 0 & 0 & 0 & 50 & 100 & 0 & 0 \\
\hline Accounting (275) & 25 & 96 & 12 & 4 & 1 & 0 & 0 & 0 \\
\hline BB only (3) & 100 & 96 & 100 & 4 & 67 & 0 & 0 & 0 \\
\hline Casinos (19) & 47 & 93 & 32 & 5 & 5 & 2 & 0 & 0 \\
\hline BB only (9) & 44 & 94 & 22 & 3 & 11 & 2 & 0 & 0 \\
\hline Service General (2346) & 33 & 93 & 22 & 7 & 1 & 0 & 0 & 0 \\
\hline BB only (56) & 46 & 94 & 30 & 6 & 5 & 0 & 2 & 0 \\
\hline Residential (16) & 75 & 99 & 38 & 1 & 0 & 0 & 0 & 0 \\
\hline Heavy Constr. (5488) & 12 & 93 & 7 & 6 & 0 & 1 & 0 & 0 \\
\hline BB only (9) & 67 & 95 & 67 & 5 & 0 & 0 & 0 & 0 \\
\hline
\end{tabular}




\begin{tabular}{|c|c|c|c|c|c|c|c|c|}
\hline Waste Mgt. (8) & 75 & 68 & 63 & 32 & 0 & 0 & 0 & 0 \\
\hline BB only (2) & 100 & 77 & 100 & 23 & 0 & 0 & 0 & 0 \\
\hline Food (1668) & 25 & 93 & 16 & 7 & 0 & 0 & 0 & 0 \\
\hline BB only (34) & 62 & 93 & 56 & 7 & 6 & 0 & 0 & 0 \\
\hline Tobacco (15) & 40 & 98 & 27 & 2 & 0 & 0 & 0 & 0 \\
\hline BB only (3) & 100 & 99 & 67 & 1 & 0 & 0 & 0 & 0 \\
\hline Textiles (13) & 31 & 88 & 23 & 12 & 0 & 0 & 0 & 0 \\
\hline BB only (1) & 0 & 0 & 0 & 0 & 0 & 0 & 0 & 0 \\
\hline Apparel (23) & 91 & 98 & 65 & 1 & 9 & 0 & 0 & 0 \\
\hline BB only (5) & 100 & 97 & 40 & 2 & 20 & 1 & 0 & 0 \\
\hline Agribusiness (120) & 10 & 93 & 3 & 7 & 0 & 0 & 0 & 0 \\
\hline BB only (1) & 100 & 100 & 0 & 0 & 0 & 0 & 0 & 0 \\
\hline Paper (300) & 24 & 78 & 22 & 22 & 0 & 0 & 0 & 0 \\
\hline BB only (8) & 63 & 78 & 63 & 22 & 0 & 0 & 0 & 0 \\
\hline Printing and Pub (14) & 71 & 95 & 50 & 5 & 0 & 0 & 0 & 0 \\
\hline BB only (1) & 100 & 83 & 100 & 17 & 0 & 0 & 0 & 0 \\
\hline Chemical (695) & 19 & 93 & 14 & 6 & 0 & 0 & 0 & 0 \\
\hline BB only (16) & 63 & 96 & 56 & 3 & 13 & 0 & 0 & 0 \\
\hline Oil (3987) & 20 & 97 & 10 & 3 & 0 & 0 & 0 & 0 \\
\hline
\end{tabular}




\begin{tabular}{|c|c|c|c|c|c|c|c|c|}
\hline BB only (62) & 60 & 95 & 55 & 5 & 2 & 0 & 0 & 0 \\
\hline Rubber (318) & 12 & 72 & 8 & 18 & 0 & 10 & 0 & 0 \\
\hline BB only (1) & 100 & 81 & 100 & 19 & 0 & 0 & 0 & 0 \\
\hline Glass (339) & 18 & 94 & 19 & 6 & 0 & 0 & 0 & 0 \\
\hline BB only (2) & 50 & 99 & 50 & 1 & 0 & 0 & 0 & 0 \\
\hline Steel (1214) & 15 & 91 & 11 & 8 & 0 & 0 & 0 & 1 \\
\hline BB only (6) & 67 & 87 & 83 & 13 & 0 & 0 & 0 & 0 \\
\hline Cosmetics (16) & 56 & 96 & 38 & 4 & 6 & 0 & 0 & 0 \\
\hline BB only (9) & 78 & 95 & 56 & 4 & 11 & 0 & 0 & 0 \\
\hline Altern Energy (22) & 50 & 98 & 23 & 2 & 0 & 0 & 0 & 0 \\
\hline Electronics (121) & 79 & 90 & 62 & 10 & 4 & 0 & 1 & 0 \\
\hline BB only (13) & 92 & 87 & 85 & 13 & 15 & 0 & 0 & 0 \\
\hline Guns, Ammo (8) & 38 & 92 & 38 & 8 & 0 & 0 & 0 & 0 \\
\hline Machinery (222) & 42 & 85 & 35 & 14 & 2 & 1 & 2 & 0 \\
\hline BB only (14) & 100 & 86 & 100 & 12 & 14 & 2 & 21 & 0 \\
\hline Defense Prod and Serv (19) & 21 & 80 & 26 & 20 & 0 & 0 & 0 & 0 \\
\hline Autos (97) & 55 & 89 & 43 & 11 & 3 & 0 & 1 & 0 \\
\hline BB only (12) & 75 & 81 & 58 & 18 & 0 & 0 & 8 & 0 \\
\hline Aerospace (31) & 58 & 80 & 45 & 19 & 16 & 0 & 10 & 0 \\
\hline
\end{tabular}




\begin{tabular}{|c|c|c|c|c|c|c|c|c|}
\hline BB only (9) & 100 & 80 & 89 & 19 & 56 & 1 & 33 & 0 \\
\hline Pharma (587) & 49 & 94 & 23 & 6 & 1 & 0 & 0 & 0 \\
\hline BB only (18) & 83 & 94 & 72 & 6 & 6 & 0 & 0 & 0 \\
\hline Computers (41) & 63 & 89 & 51 & 11 & 2 & 0 & 2 & 0 \\
\hline BB only (17) & 59 & 90 & 41 & 10 & 6 & 0 & 6 & 0 \\
\hline Internet Mfgr (17) & 94 & 88 & 94 & 12 & 18 & 0 & 6 & 0 \\
\hline BB only (2) & 100 & 91 & 100 & 9 & 100 & 0 & 50 & 0 \\
\hline Software (138) & 76 & 90 & 64 & 10 & 9 & 0 & 1 & 0 \\
\hline BB only (30) & 63 & 90 & 40 & 10 & 23 & 0 & 7 & 0 \\
\hline Telecom (1552) & 30 & 98 & 17 & 2 & 1 & 0 & 0 & 0 \\
\hline BB only (49) & 63 & 99 & 37 & 1 & 14 & 0 & 8 & 0 \\
\hline Beverages (38) & 53 & 98 & 37 & 2 & 3 & 0 & 0 & 0 \\
\hline BB only (5) & 80 & 98 & 60 & 2 & 20 & 0 & 0 & 0 \\
\hline Health (29951) & 32 & 91 & 16 & 9 & 0 & 1 & 0 & 0 \\
\hline BB only (17) & 72 & 99 & 61 & 1 & 11 & 0 & 6 & 0 \\
\hline Health Insur. (23) & 83 & 97 & 78 & 3 & 17 & 0 & 0 & 0 \\
\hline BB only (10) & 100 & 97 & 100 & 3 & 40 & 0 & 0 & 0 \\
\hline Credit Reporting (10) & 80 & 93 & 70 & 7 & 0 & 0 & 0 & 0 \\
\hline BB only (2) & 100 & 95 & 100 & 5 & 0 & 0 & 0 & 0 \\
\hline
\end{tabular}




\begin{tabular}{|c|c|c|c|c|c|c|c|c|}
\hline BB only (1) & 100 & 100 & 0 & 0 & 0 & 0 & 0 & 0 \\
\hline Auto Dealers (3188) & 9 & 92 & 7 & 7 & 0 & 1 & 0 & 0 \\
\hline BB only (7) & 71 & 84 & 43 & 15 & 14 & 1 & 0 & 0 \\
\hline Transp, Trk, RR (1659) & 13 & 94 & 9 & 6 & 0 & 0 & 0 & 0 \\
\hline BB only (11) & 64 & 81 & 64 & 19 & 9 & 0 & 0 & 0 \\
\hline Airlines (14) & 79 & 85 & 71 & 13 & 29 & 2 & 7 & 0 \\
\hline BB only (4) & 100 & 86 & 100 & 13 & 75 & 1 & 25 & 0 \\
\hline Utilities (2582) & 12 & 90 & 12 & 9 & 0 & 1 & 0 & 0 \\
\hline BB only (19) & 95 & 94 & 89 & 6 & 5 & 0 & 11 & 0 \\
\hline Commun (14) & 57 & 94 & 57 & 4 & 21 & 1 & 7 & 0 \\
\hline BB only (5) & 60 & 93 & 60 & 5 & 40 & 2 & 20 & 0 \\
\hline $\begin{array}{l}\text { Mortg and Non-Bk Lending } \\
(136)\end{array}$ & 33 & 90 & 18 & 9 & 1 & 1 & 1 & 0 \\
\hline BB only (5) & 80 & 90 & 60 & 9 & 20 & 1 & 20 & 0 \\
\hline Real Estate (12451) & 21 & 98 & 7 & 1 & 1 & 0 & 0 & 0 \\
\hline BB only (36) & 39 & 100 & 3 & 0 & 3 & 0 & 0 & 0 \\
\hline Insurance (4927) & 15 & 93 & 7 & 6 & 0 & 0 & 0 & 0 \\
\hline BB only (35) & 91 & 93 & 89 & 7 & 11 & 0 & 0 & 0 \\
\hline Comm Banking (3971) & 20 & 92 & 9 & 3 & 1 & 5 & 0 & 0 \\
\hline BB only (18) & 72 & 98 & 67 & 2 & 22 & 0 & 0 & 0 \\
\hline
\end{tabular}




\begin{tabular}{|c|c|c|c|c|c|c|c|}
\hline $\begin{array}{c}\text { Invest and Hedge Funds } \\
\text { (285) }\end{array}$ & 36 & 100 & 7 & 0 & 0 & 0 \\
\hline BB only (47) & 45 & 100 & 9 & 0 & 6 & 0 & 0 \\
\hline Priv Equity (14880) & 29 & 99 & 7 & 1 & 1 & 0 & 0 \\
\hline BB only (38) & 42 & 100 & 0 & 0 & 0 & 0 & 0 \\
\hline Brokers, Mut Fd (43) & 63 & 95 & 49 & 4 & 7 & 0 & 2 \\
\hline BB only (6) & 50 & 97 & 33 & 3 & 17 & 0 & 0 \\
\hline Retailing (195) & 69 & 93 & 58 & 7 & 3 & 0 & 0 \\
\hline BB only (68) & 75 & 92 & 62 & 8 & 6 & 0 & 0 \\
\hline 100 Small Bus nec (512364) & 28 & 89 & 16 & 10 & 0 & 0 \\
\hline
\end{tabular}

Source: Computed by Authors From FEC and IRS Data 
Figure 3

Money and Votes in 2016 Congressional Elections

Sources: Data From FEC and IRS, Authors Calculations

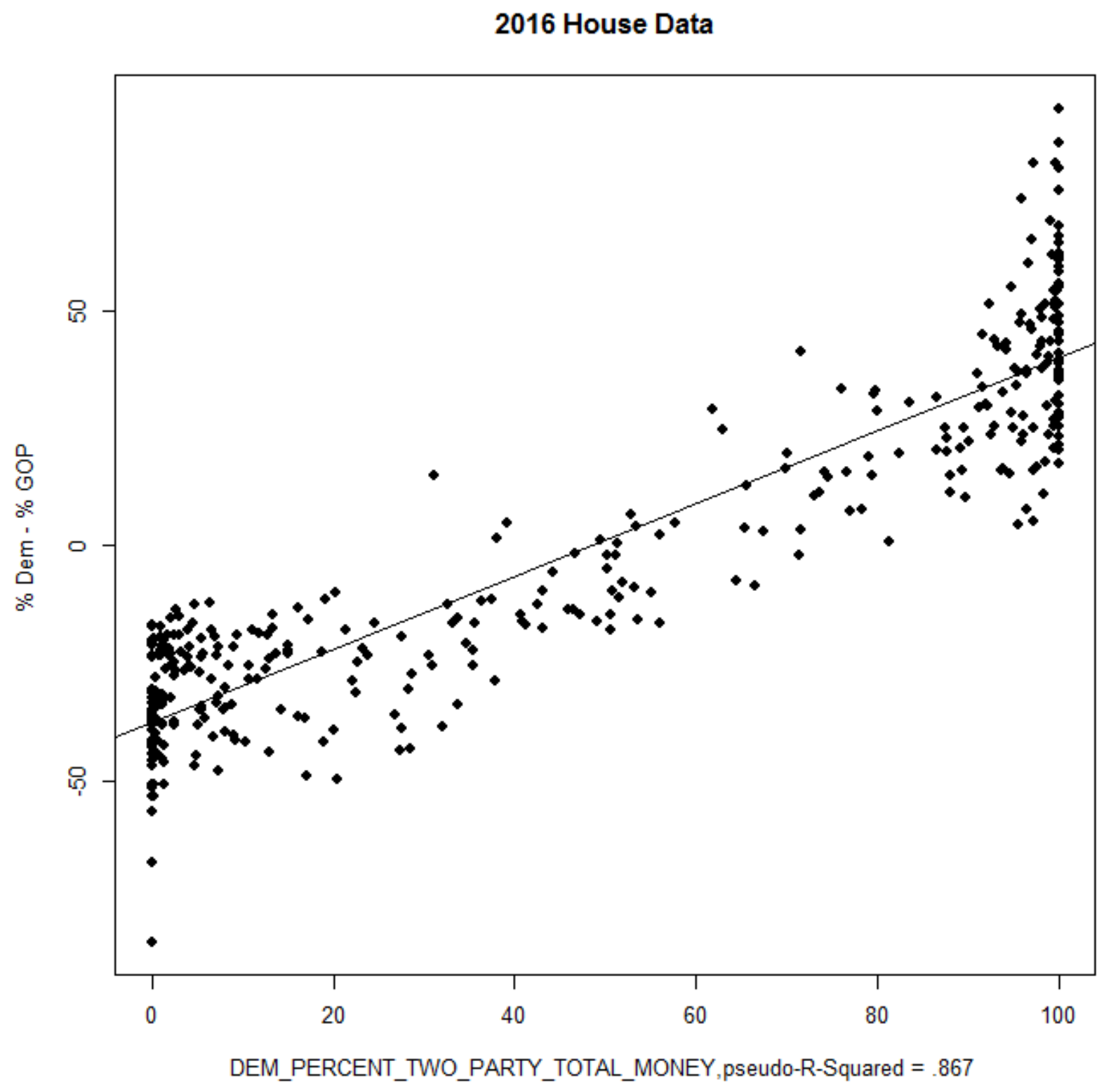

Regression, Spatial Latent Instrumental Variable Model 


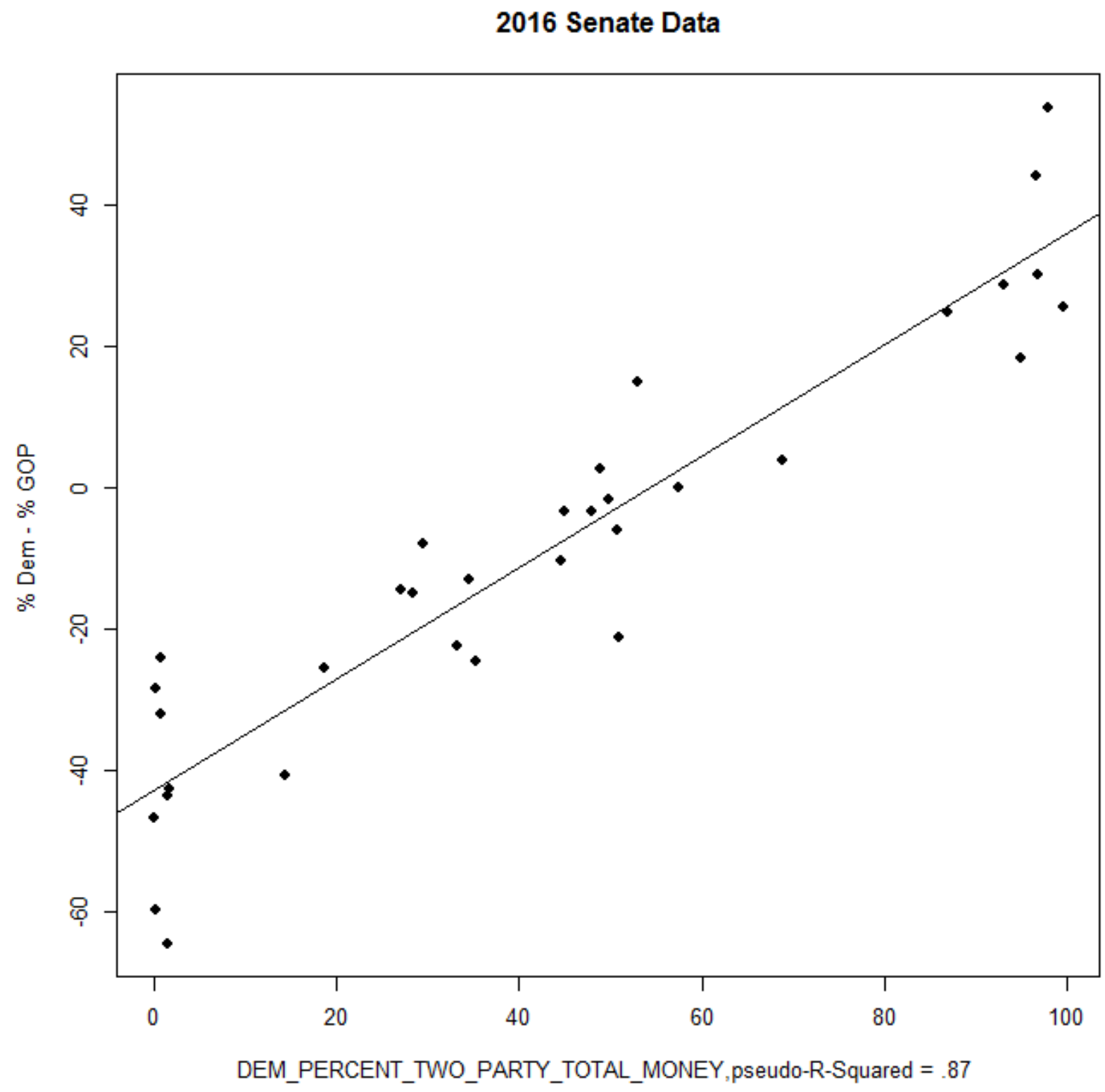

Sources: Data From FEC and IRS, Authors Calculations

Regression, Spatial Latent Instrumental Variable Model 
Figure 4

Total Money Flow into Trump Campaign; Romney 2012 Used for Comparison

Source: Computed by Authors From FEC and IRS Data

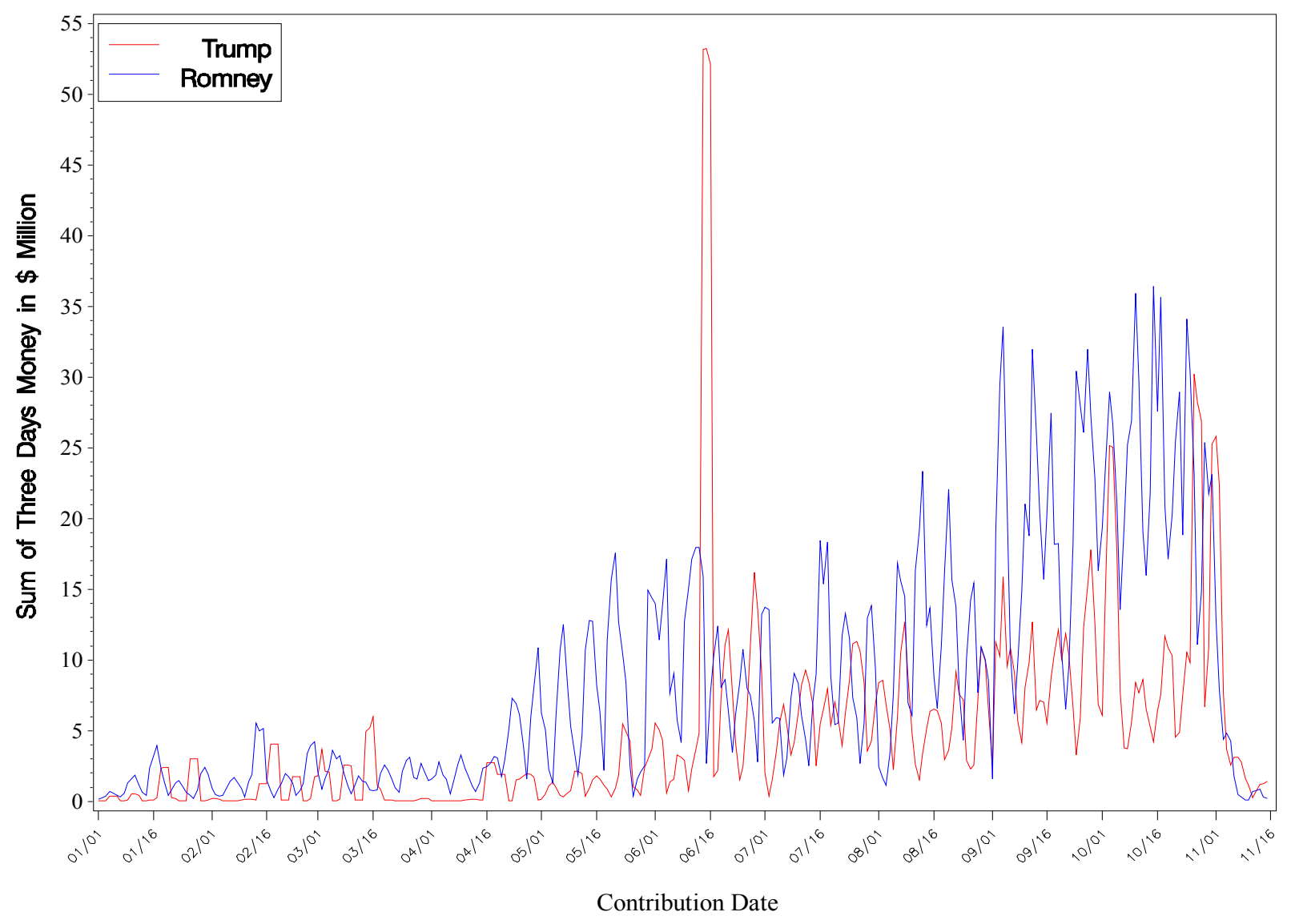


Table 6

Three Stages of the Trump Campaign

\begin{tabular}{|c|c|c|c|c|c|c|c|c|}
\hline Industry (N) & $\begin{array}{l}\text { Trump } \\
\% \text { of firms }\end{array}$ & $\begin{array}{l}\text { Trump } \\
\text { Money }\end{array}$ & $\begin{array}{c}\text { Trump } \\
\text { \% of firms } \\
\text { Before May } 04\end{array}$ & $\begin{array}{c}\text { Trump } \\
\text { \% of Money } \\
\text { Before May } \\
04\end{array}$ & $\begin{array}{c}\text { \% of firms } \\
\text { May 04- } \\
\text { Aug12 }\end{array}$ & $\begin{array}{c}\text { \% of Money } \\
\text { May 04-Aug } \\
12\end{array}$ & $\begin{array}{c}\% \text { of firms } \\
\text { After Aug } \\
13 .\end{array}$ & $\begin{array}{l}\text { Trump } \\
\% \text { of Money } \\
\text { After Aug } 13\end{array}$ \\
\hline Mining (26) & 38 & 277,462 & 8 & 0 & 31 & 96 & 27 & 4 \\
\hline BB only (2) & 50 & 268,133 & 50 & 0 & 50 & 98 & 50 & 2 \\
\hline Coal Mining (147) & 37 & $2,434,624$ & 3 & 0 & 25 & 46 & 22 & 54 \\
\hline BB only (2) & 100 & 401,000 & 0 & 0 & 0 & 0 & 100 & 100 \\
\hline Accounting (275) & 21 & 494,168 & 3 & 1 & 15 & 51 & 15 & 48 \\
\hline BB only (3) & 100 & 373,843 & 67 & 0 & 100 & 47 & 100 & 53 \\
\hline Casinos (19) & 68 & $23,448,870$ & 16 & 0 & 26 & 2 & 68 & 98 \\
\hline BB only (9) & 89 & $23,412,279$ & 22 & 0 & 33 & 2 & 89 & 98 \\
\hline $\begin{array}{l}\text { Service General } \\
(2346)\end{array}$ & 17 & $11,628,129$ & 1 & 0 & 10 & 48 & 13 & 52 \\
\hline BB only (56) & 50 & $10,139,577$ & 11 & 0 & 39 & 48 & 38 & 52 \\
\hline Residential (16) & 56 & 66,012 & 0 & 0 & 44 & 84 & 56 & 16 \\
\hline $\begin{array}{c}\text { Heavy Constr. } \\
(5488)\end{array}$ & 25 & $3,310,486$ & 1 & 2 & 12 & 38 & 19 & 60 \\
\hline
\end{tabular}




\begin{tabular}{|c|c|c|c|c|c|c|c|c|}
\hline BB only (9) & 67 & 67,209 & 22 & 5 & 67 & 33 & 56 & 62 \\
\hline Waste Mgt. (8) & 50 & 8,886 & 13 & 6 & 50 & 49 & 50 & 45 \\
\hline BB only (2) & 100 & 7,104 & 50 & 7 & 100 & 45 & 100 & 48 \\
\hline Food (1668) & 21 & $1,330,344$ & 1 & 1 & 10 & 32 & 17 & 67 \\
\hline BB only (34) & 59 & 176,956 & 12 & 2 & 38 & 68 & 50 & 30 \\
\hline Tobacco (15) & 27 & 138,285 & 0 & 0 & 20 & 75 & 27 & 25 \\
\hline BB only (3) & 100 & 135,375 & 0 & 0 & 100 & 76 & 100 & 24 \\
\hline Textiles (13) & 23 & 1,787 & 8 & 0 & 23 & 42 & 23 & 58 \\
\hline Apparel (23) & 35 & 500,174 & 4 & 1 & 26 & 12 & 26 & 87 \\
\hline BB only (5) & 60 & 403,185 & 0 & 0 & 40 & 0 & 60 & 100 \\
\hline Agribusiness (120) & 11 & 67,034 & 1 & 0 & 5 & 20 & 9 & 80 \\
\hline Paper (300) & 28 & 213,282 & 2 & 1 & 16 & 36 & 21 & 63 \\
\hline BB only (8) & 63 & 39,575 & 25 & 3 & 63 & 28 & 63 & 69 \\
\hline $\begin{array}{l}\text { Printing and Pub } \\
\text { (14) }\end{array}$ & 43 & 67,739 & 21 & 2 & 29 & 11 & 29 & 87 \\
\hline BB only (1) & 100 & 53,586 & 100 & 1 & 100 & 1 & 100 & 98 \\
\hline Chemical (695) & 31 & $1,086,241$ & 3 & 2 & 17 & 77 & 25 & 21 \\
\hline BB only (16) & 69 & 193,337 & 19 & 1 & 56 & 84 & 56 & 15 \\
\hline
\end{tabular}




\begin{tabular}{|c|c|c|c|c|c|c|c|c|}
\hline Oil (3987) & 27 & $6,835,437$ & 2 & 1 & 14 & 47 & 21 & 52 \\
\hline BB only (62) & 73 & $2,779,747$ & 23 & 0 & 61 & 58 & 65 & 42 \\
\hline Rubber (318) & 36 & 343,720 & 3 & 1 & 21 & 65 & 28 & 34 \\
\hline BB only (1) & 100 & 152,701 & 0 & 0 & 100 & 99 & 100 & 1 \\
\hline Glass (339) & 26 & 71,417 & 2 & 2 & 16 & 37 & 18 & 61 \\
\hline BB only (2) & 50 & 1,703 & 0 & 0 & 50 & 33 & 50 & 67 \\
\hline Steel (1214) & 35 & $1,122,892$ & 2 & 2 & 20 & 34 & 26 & 64 \\
\hline BB only (6) & 67 & 59,381 & 17 & 3 & 67 & 27 & 67 & 70 \\
\hline Cosmetics (16) & 44 & $1,149,938$ & 0 & 0 & 31 & 45 & 44 & 55 \\
\hline BB only (9) & 56 & 255,428 & 0 & 0 & 44 & 30 & 56 & 70 \\
\hline Altern Energy (22) & 14 & 12,125 & 5 & 2 & 5 & 1 & 14 & 97 \\
\hline Electronics (121) & 70 & 853,526 & 12 & 1 & 43 & 14 & 60 & 85 \\
\hline BB only (13) & 85 & 481,568 & 23 & 1 & 77 & 9 & 85 & 90 \\
\hline Guns, Ammo (8) & 38 & 82,984 & 13 & 3 & 25 & 84 & 25 & 13 \\
\hline Machinery (222) & 39 & 752,235 & 4 & 1 & 26 & 57 & 36 & 42 \\
\hline BB only (14) & 93 & 458,352 & 29 & 0 & 71 & 48 & 93 & 52 \\
\hline $\begin{array}{c}\text { Defense Prod and } \\
\text { Serv (19) }\end{array}$ & 21 & 6,370 & 0 & 0 & 16 & 24 & 21 & 76 \\
\hline
\end{tabular}




\begin{tabular}{|c|c|c|c|c|c|c|c|c|}
\hline Autos (97) & 44 & 915,507 & 7 & 0 & 28 & 17 & 39 & 83 \\
\hline BB only (12) & 67 & 768,004 & 17 & 0 & 50 & 5 & 67 & 95 \\
\hline Aerospace (31) & 58 & 531,683 & 19 & 1 & 52 & 55 & 55 & 44 \\
\hline BB only (9) & 89 & 508,477 & 67 & 1 & 89 & 56 & 89 & 43 \\
\hline Pharma (587) & 22 & $1,065,685$ & 3 & 3 & 14 & 69 & 18 & 28 \\
\hline BB only (18) & 83 & 204,589 & 28 & 1 & 72 & 33 & 83 & 66 \\
\hline Computers (41) & 46 & 292,480 & 20 & 2 & 39 & 51 & 37 & 47 \\
\hline BB only (17) & 41 & 235,760 & 24 & 1 & 35 & 57 & 29 & 42 \\
\hline Internet Mfgr (17) & 76 & $2,327,028$ & 41 & 0 & 76 & 12 & 65 & 88 \\
\hline BB only (2) & 100 & $2,293,741$ & 100 & 0 & 100 & 12 & 100 & 88 \\
\hline Software (138) & 57 & $2,552,028$ & 15 & 0 & 43 & 8 & 51 & 92 \\
\hline BB only (30) & 50 & $2,116,190$ & 20 & 0 & 43 & 4 & 47 & 96 \\
\hline Telecom (1552) & 17 & $5,874,713$ & 2 & 0 & 9 & 30 & 13 & 70 \\
\hline BB only (49) & 39 & $4,400,873$ & 20 & 0 & 39 & 31 & 35 & 69 \\
\hline Beverages (38) & 42 & 263,306 & 11 & 2 & 34 & 53 & 32 & 45 \\
\hline BB only (5) & 60 & 139,553 & 40 & 0 & 60 & 49 & 40 & 51 \\
\hline Health (29951) & 16 & $8,166,200$ & 1 & 5 & 8 & 40 & 13 & 55 \\
\hline
\end{tabular}




\begin{tabular}{|c|c|c|c|c|c|c|c|c|}
\hline BB only (17) & 65 & 527,131 & 29 & 1 & 59 & 93 & 65 & 6 \\
\hline Health Insur. (23) & 78 & 611,632 & 30 & 1 & 61 & 67 & 78 & 32 \\
\hline BB only (10) & 100 & 569,667 & 50 & 1 & 100 & 69 & 100 & 30 \\
\hline $\begin{array}{l}\text { Credit Reporting } \\
\text { (10) }\end{array}$ & 70 & 342,857 & 10 & 0 & 60 & 5 & 60 & 95 \\
\hline BB only (2) & 100 & 123,234 & 0 & 0 & 100 & 1 & 100 & 99 \\
\hline Auto Dealers (3188) & 19 & $1,908,866$ & 1 & 1 & 10 & 22 & 14 & 77 \\
\hline BB only (7) & 71 & 3,665 & 0 & 0 & 43 & 41 & 71 & 59 \\
\hline $\begin{array}{c}\text { Transp, Trk, RR } \\
\text { (1659) }\end{array}$ & 26 & $1,391,134$ & 2 & 1 & 13 & 40 & 19 & 59 \\
\hline BB only (11) & 64 & 100,799 & 36 & 1 & 55 & 66 & 64 & 33 \\
\hline Airlines (14) & 71 & 535,884 & 43 & 2 & 57 & 38 & 71 & 60 \\
\hline BB only (4) & 100 & 507,371 & 100 & 2 & 100 & 39 & 100 & 59 \\
\hline Utilities (2582) & 24 & 845,433 & 1 & 2 & 13 & 48 & 18 & 50 \\
\hline BB only (19) & 95 & 153,660 & 42 & 3 & 84 & 51 & 95 & 46 \\
\hline Commun (14) & 21 & 109,936 & 7 & 0 & 21 & 6 & 21 & 94 \\
\hline BB only (5) & 40 & 108,886 & 20 & 0 & 40 & 6 & 40 & 94 \\
\hline $\begin{array}{l}\text { Mortg and Non-Bk } \\
\text { Lending (136) }\end{array}$ & 27 & 262,872 & 1 & 1 & 18 & 74 & 20 & 25 \\
\hline
\end{tabular}




\begin{tabular}{|c|c|c|c|c|c|c|c|c|}
\hline BB only (5) & 100 & 127,403 & 0 & 0 & 60 & 63 & 80 & 37 \\
\hline Real Estate (12451) & 20 & $10,680,447$ & 1 & 4 & 10 & 39 & 15 & 57 \\
\hline BB only (36) & 22 & $1,021,894$ & 3 & 0 & 11 & 29 & 19 & 71 \\
\hline Insurance (4927) & 18 & $2,712,087$ & 1 & 1 & 10 & 50 & 13 & 49 \\
\hline BB only (35) & 91 & 507,872 & 46 & 2 & 86 & 46 & 89 & 52 \\
\hline $\begin{array}{c}\text { Comm Banking } \\
(3971)\end{array}$ & 16 & $8,590,666$ & 1 & 2 & 10 & 33 & 12 & 65 \\
\hline BB only (18) & 78 & $1,808,447$ & 56 & 6 & 72 & 78 & 67 & 16 \\
\hline $\begin{array}{l}\text { Invest and Hedge } \\
\text { Funds (285) }\end{array}$ & 17 & $3,973,409$ & 4 & 13 & 11 & 75 & 13 & 12 \\
\hline BB only (47) & 17 & $1,162,999$ & 9 & 43 & 13 & 35 & 9 & 22 \\
\hline Priv Equity (14880) & 15 & $23,115,940$ & 1 & 2 & 8 & 40 & 11 & 58 \\
\hline BB only (38) & 21 & $2,067,692$ & 3 & 0 & 18 & 22 & 11 & 78 \\
\hline Brokers, Mut Fd (43) & 47 & 321,117 & 21 & 1 & 33 & 82 & 37 & 17 \\
\hline BB only (6) & 33 & 225,164 & 33 & 1 & 33 & 96 & 17 & 3 \\
\hline Retailing (195) & 53 & $1,515,087$ & 10 & 1 & 40 & 34 & 45 & 65 \\
\hline BB only (68) & 62 & 807,657 & 21 & 1 & 56 & 49 & 51 & 50 \\
\hline $\begin{array}{c}100 \text { Small Bus nec } \\
(512364)\end{array}$ & 14 & $168,344,380$ & 1 & 2 & 7 & 60 & 10 & 38 \\
\hline
\end{tabular}


Table 7

Clinton vs. Trump

Industry Differences in Major Party Candidate Support 2016: Firm Contributions and Distribution of Money (in \% -- Subtract Clinton \% From 100\% for Trump \%)

\begin{tabular}{|c|c|c|c|}
\hline \multirow[t]{3}{*}{ INDUSTRY (N) } & CLINTON & CLINTON & TRUMP \\
\hline & $\% \mathrm{OF}$ & $\%$ OF MONEY & $\%$ OF FIRMS \\
\hline & FIRMS & & \\
\hline Mining (26) & 30.77 & 8.10 & 38.46 \\
\hline BB only (2) & 100.00 & 4.16 & 50.00 \\
\hline Coal Mining (147) & 6.12 & 0.74 & $37.41 * *$ \\
\hline BB only (2) & 0.00 & 0.00 & 100.00 \\
\hline Accounting (275) & 24.73 & 80.39 & 21.45 \\
\hline BB only (3) & 100.00 & 83.49 & 100.00 \\
\hline Casinos (19) & 47.37 & 0.54 & $68.42 *$ \\
\hline BB only (9) & 44.44 & 0.45 & $88.89 *$ \\
\hline Service General (2346) & 32.65 & 40.05 & $16.62 * *$ \\
\hline BB only (56) & 46.43 & 21.49 & 50.00 \\
\hline Residential (16) & 75.00 & 72.91 & 56.25 \\
\hline Heavy Constr. (5488) & 11.90 & 46.66 & $24.87^{* *}$ \\
\hline BB only (9) & 66.67 & 91.89 & 66.67 \\
\hline Waste Mgt. (8) & 75.00 & 66.54 & $50.00(.157)$ \\
\hline BB only (2) & 100.00 & 66.11 & 100.00 \\
\hline Food (1668) & 25.00 & 56.42 & $21.46^{*}$ \\
\hline BB only (34) & 61.76 & 68.89 & 58.82 \\
\hline Tobacco (15) & 40.00 & 52.57 & 26.67(.157) \\
\hline BB only (3) & 100.00 & 52.96 & 100.00 \\
\hline Textiles (13) & 30.77 & 83.05 & 23.08 \\
\hline Apparel (23) & 91.30 & 69.16 & $34.78 * *$ \\
\hline BB only (5) & 100.00 & 49.14 & 60.00 \\
\hline Agribusiness (120) & 10.00 & 31.33 & 10.83 \\
\hline BB only (1) & 100.00 & 100.00 & 0.00 \\
\hline Paper (300) & 23.67 & 42.86 & $28.33(.194)$ \\
\hline BB only (8) & 62.50 & 51.85 & 62.50 \\
\hline Printing and Pub (14) & 71.43 & 81.52 & $42.86^{*}$ \\
\hline BB only (1) & 100.00 & 30.84 & 100.00 \\
\hline Chemical (695) & 18.99 & 52.21 & $31.22 * *$ \\
\hline BB only (16) & 62.50 & 81.54 & 68.75 \\
\hline Oil (3987) & 19.71 & 54.86 & $27.09 * *$ \\
\hline BB only (62) & 59.68 & 31.03 & $72.58^{*}$ \\
\hline
\end{tabular}




\begin{tabular}{|c|c|c|c|}
\hline Rubber (318) & 11.64 & 14.09 & $36.16^{* *}$ \\
\hline BB only (1) & 100.00 & 5.24 & 100.00 \\
\hline Glass (339) & 17.70 & 88.36 & $26.25 * *$ \\
\hline BB only (2) & 50.00 & 99.58 & 50.00 \\
\hline Steel (1214) & 14.74 & 35.18 & $35.01 * *$ \\
\hline BB only (6) & 66.67 & 43.22 & 66.67 \\
\hline Cosmetics (16) & 56.25 & 24.54 & 43.75 \\
\hline BB only (9) & 77.78 & 58.63 & 55.56 \\
\hline Altern Energy (22) & 50.00 & 88.06 & $13.64 * *$ \\
\hline Electronics (121) & 78.51 & 70.47 & $70.25^{*}$ \\
\hline BB only (13) & 92.31 & 56.14 & 84.62 \\
\hline Guns, Ammo (8) & 37.50 & 24.18 & 37.50 \\
\hline Machinery (222) & 42.34 & 50.61 & 39.19 \\
\hline BB only (14) & 100.00 & 51.65 & 92.86 \\
\hline Defense Prod and Serv (19) & 21.05 & 84.62 & 21.05 \\
\hline Autos (97) & 54.64 & 53.17 & 44.33 \\
\hline BB only (12) & 75.00 & 30.80 & 66.67 \\
\hline Aerospace (31) & 58.06 & 69.22 & 58.06 \\
\hline BB only (9) & 100.00 & 68.37 & 88.89 \\
\hline Pharma (587) & 48.89 & 74.57 & $21.81 * *$ \\
\hline BB only (18) & 83.33 & 89.57 & 83.33 \\
\hline Computers (41) & 63.41 & 90.98 & $46.34(.071)$ \\
\hline BB only (17) & 58.82 & 92.44 & 41.18 \\
\hline Internet Mfgr (17) & 94.12 & 30.57 & $76.47(.180)$ \\
\hline BB only (2) & 100.00 & 28.03 & 100.00 \\
\hline Software (138) & 76.09 & 80.86 & $57.25 * *$ \\
\hline BB only (30) & 63.33 & 79.60 & 50.00 \\
\hline Telecom (1552) & 30.41 & 87.64 & $17.07 * *$ \\
\hline BB only (49) & 63.27 & 88.50 & $38.78 * *$ \\
\hline Beverages (38) & 52.63 & 84.03 & 42.11 \\
\hline BB only (5) & 80.00 & 84.35 & 60.00 \\
\hline Health (29951) & 31.67 & 80.61 & $16.17^{* *}$ \\
\hline BB only (17) & 76.47 & 93.45 & 64.71 \\
\hline Health Insur. (23) & 82.61 & 91.20 & 78.26 \\
\hline BB only (10) & 100.00 & 91.48 & 100.00 \\
\hline Credit Reporting (10) & 80.00 & 50.43 & 70.00 \\
\hline BB only (2) & 100.00 & 63.92 & 100.00 \\
\hline BB only (1) & 100.00 & 100.00 & 0.00 \\
\hline Auto Dealers (3188) & 9.22 & 31.91 & $19.04 * *$ \\
\hline BB only (7) & 71.43 & 84.54 & 71.43 \\
\hline Transp, Trk, RR (1659) & 12.90 & 57.23 & $25.86 * *$ \\
\hline BB only (11) & 63.64 & 59.95 & 63.64 \\
\hline Airlines (14) & 78.57 & 66.20 & 71.43 \\
\hline
\end{tabular}




\begin{tabular}{|c|c|c|c|}
\hline BB only (4) & 100.00 & 66.15 & 100.00 \\
\hline Utilities (2582) & 11.89 & 71.64 & $24.36 * *$ \\
\hline BB only (19) & 94.74 & 90.40 & 94.74 \\
\hline Commun (14) & 57.14 & 85.96 & $21.43^{*}$ \\
\hline BB only (5) & 60.00 & 82.27 & 40.00 \\
\hline $\begin{array}{l}\text { Mortg and Non-Bk Lending } \\
\text { (136) }\end{array}$ & 33.09 & 55.18 & 27.21 \\
\hline BB only (5) & 80.00 & 62.92 & 100.00 \\
\hline Real Estate (12451) & 20.87 & 78.57 & $19.97(.090)$ \\
\hline BB only (36) & 38.89 & 95.66 & $22.22(.180)$ \\
\hline Insurance (4927) & 15.06 & 64.79 & 18.25 \\
\hline BB only (35) & 91.43 & 83.48 & 91.43 \\
\hline Comm Banking (3971) & 20.02 & 56.03 & $16.17^{* *}$ \\
\hline BB only (18) & 72.22 & 77.70 & 77.78 \\
\hline Invest and Hedge Funds (285) & 36.14 & 90.92 & $17.19 * *$ \\
\hline BB only (47) & 44.68 & 96.61 & $17.02 * *$ \\
\hline Priv Equity (14880) & 28.74 & 77.87 & $15.43 * *$ \\
\hline BB only (38) & 42.11 & 53.69 & $21.05(.074)$ \\
\hline Brokers, Mut Fd (43) & 62.79 & 78.60 & $46.51 *$ \\
\hline BB only (6) & 50.00 & 65.45 & 33.33 \\
\hline Retailing (195) & 69.23 & 81.26 & $53.338 *$ \\
\hline BB only (68) & 75.00 & 86.44 & $61.76^{*}$ \\
\hline 100 Small Bus nec (512364) & 27.97 & 67.88 & $14.13 * *$ \\
\hline
\end{tabular}

Note that: BB only = only firms in big business in the industry just above. ${ }^{* *}$ and $*$ differences between percentages of support from firms for Clinton and Trump are significant at the .01 and .05 level respectively using the McNemar test and repeated logistic model. Other significance levels are reported in parentheses; if nothing is reported, the differences are insignificant.

Source: Computed by Authors From FEC and IRS Data 


\section{Table 8}

Size of Contributions to Trump Inaugural Celebration

$\begin{array}{lc}\text { AMOUNT } & \text { PERCENT OF TOTAL } \\ \text { UNITEMIZED } & .6 \\ <=\$ 250 & .02 \\ 251-499 & .05 \\ 500-999 & .03 \\ 1,000-9,999 & .36 \\ 10,000-99,9999 & 5.76 \\ >=100,000 & 93.17\end{array}$

The average of those gifts totaling $\$ 100,000$ or more is $\$ 405,841$.

Source: See Text 


\section{References}

AD HOC COMMITTEE, American Association for Opinion Research. 2017. An Evaluation of 2016 Election Polls in the U.S.: American Association for Opinion Research.

ALBRIGHT, J. 2016. Left+Right: The Combined Post-\#Election News "Ecosystem". Medium, December 11,2016.

ALBRIGHT, J. 2017a. Total Reach by Page. Tableau Public, October 5, 2017.

ALBRIGHT, J. 2017b. Who Hacked the Election? Ad Tech Did. Through "Fake News," Identity Resolution, and Hyper-Personalization. Medium, July 31, 2017.

ALLCOTT, H. \& GENTZKOW, M. 2017. Social Media and Fake News in the 2016 Election. Journal of Economic Perspectives, 31, 211-36.

ALLEN, J. \& PARNES, A. 2017. Shattered -- Inside Hillary Clinton's Doomed Campaign, New York, Crown.

ANNE, R. 2017. Sinclair Broadcast Group -- The Greatest Threat to Our Democracy Since Fox News. Rantt, September 6, 2017.

ASSANGE, J. 2014. When Google Met Wikileaks, New York, OR Books.

AUTOR, D., DORN, D., HANSON, G. \& MAJLESI, K. 2016. Importing Political Polarization? The Electoral Consequences of Rising Trade Exposure. Cambridge, Massachusetts: Massachusetts Institute of Technology. Working Paper No. 22637.

AUTOR, D., DORN, D., HANSON, G. \& MAJLESI, K. 2017. A Note on the Effect of Rising Trade Exposure on the 2016 Election. Cambridge, Massachusetts: Massachusetts Institute of Technology. On the web at https://economics.mit.edu/files/12418

BALLHAUS, R. \& BYKOWICZ, J. 2017. Data Firm's WikiLeaks Outreach Came As It Joined Trump's Campaign. Wall Street Journal, November10, 2017.

BARAJAS, M. 2016. "Project Alamo": Lessons From Inside Trump's SA-Based Digital Nerve Center. San Antonio Current, October 27, 2017.

BARTELS, L. 2016. 2016 Was An Ordinary Election, Not A Realignment. Washington Post, November 10, 2016.

BEHRAKIS, Y. 2014. German Official Says It Was Wrong to Make Ukraine Pick Between EU and Russia. Reuters, May 14, 2014.

BENTELE, K. \& O'BRIEN, E. 2013. Jim Crow 2.0? Why States Consider and Adopt Restrictive Voter Access Policies. Perspectives on Politics, 11, 1088-1116.

BERNSTEIN, J. 2017. Alt-White: How the Breitbart Machine Laundered Racist Hate. BuzzFeed, October 5, 2017.

BERTRAND, N. 2017. Shuttered Facebook Group That Organized Anti-Clinton, AntiImmigrant Rallies Across Texas Was Linked To Russia. Business Insider, September 13, 2017.

BLAIR, G. 2015. The Trumps, New York, Simon \& Schuster.

BLOCK, S. 2017. The Trump Administration Will Always Side With Corporations Over Labor. Truthout, September 17, 2017.

BLUMENTHAL, P. 2017. Billionaires, Big Oil Flooded Mitch McConnell's Super PAC in Campaign's Final Weeks. Huffington Post, December 8, 2016.

BORGER, J. 2017. Investigators Explore If Russian Colluded With Pro-Trump Sites During Election. Guardian, July 5, 2017. 
BOXELL, L., GENTZKOW, M. \& SCHAPIRO, J. M. 2017. Is the Internet Causing Political Polarization? Evidence From Demographics. On the web at: https://www.brown.edu/Research/Shapiro/pdfs/age-polars.pdf

BRAZILE, D. 2017. Hacks, New York, Hachette.

BRENNAN, J. 2017. House Intel Committee Hearing; Brennan on Contact with Russia. CNN Transcripts, May 23, 2017.

BROX, B. J. \& GIAMMO, J. D. 2009. Late Deciders in US Presidential Elections. American Review of Politics, 30, 333-55.

BUMP, P. 2017. "60 Minutes" Profiles the Genius Who Won Trump's Campagin. Washington Post, October 9, 2017.

BURNHAM, W. D. \& FERGUSON, T. 2014. Americans Are Sick to Death of Both Parties: Why Our Political System Is in Worse Shape Than We Thought. AlterNet, March 30, 2015. On the web at: https://www.alternet.org/americans-are-sick-death-both-partieswhy-our-politics-worse-shape-we-thought

CADWALLADR, C. 2017a. The Great British Brexit Robbery: How Our Democracy Was Hijacked. Guardian, May 7, 2017.

CADWALLADR, C. 2017b. Robert Mercer: The Big Data Billionaire Waging War on Mainstream Media. Guardian, February 26, 2017.

CASE, A. \& DEATON, A. 2017. Mortality and Morbidity in the Twenty-First Century. Washington, D.C.: Brookings Institution.

CHOZICK, A. 2016. Hillary Clinton's Expectations, and Her Ultimate Campaign Missteps. New York Times, November 9, 2016.

CILLUFO, A. 2017. Five Facts About Student Debt. Fact Tank. Washington, D.C.: Pew Research Center.

CLINTON, H. 2017. What Happened, New York, Simon \& Schuster.

COHN, N. 2016. A 2016 Review: There's Reason To Be Skeptical of A Comey Effect. New York Times, May 8, 2017.

COLLINS, B., RESNICK, G., POULSEN, G. \& ACKERMAN, S. 2017. Exclusive: Russians Appear To Use Facebook to Push Trump Rallies in 17 US Cities. Daily Beast, September 20, 2017.

COOPER, M. 2016. Overcharged and Underserved. New York: Roosevelt Institute.

COSTA, R., DELREAL, J. A. \& JOHNSON, J. 2016. Trump Shakes Up Campaign, Demotes Top Adviser. Washington Post, August 17, 2016.

COSTANTINI, O. 2015. The Cyclically Adjusted Budget: The History and Exegesis of a Fateful Estimate. Institute for New Economic Thinking Working Paper No.24.

CROTTY, W. (ed.) 2017. Winning the Presidency 2016, New York: Routledge.

DE PLOEG, C. K. 2017. Ukraine in the Crossfire, Atlanta, Clarity Press.

DESILVER, D. 2016. Turnout Was High in the 2016 Primary Season, But Just Short of 2008 Record. FactTank. Washington, D.C.: Pew Research Center.

DICKERSON, C. 2017. How Fake News Turned A Small Town Upside Down. New York Times, September 26, 2017.

DIJULIO, B., KIRZINGER, A., WU, B. \& BRODIE, M. 2017. Data Note: Americans' Challenges With Health Care Costs. Kaiser Family Foundation.

DIPPEL, C., HEBLICH, S. \& GOLD, R. 2015. Globalization and Its (Dis-)Content: Trade Shocks and Voting Behavior. Cambridge: National Bureau of Economic Research. 
DOWARD, J. \& GIBBS, A. 2017. Did Cambridge Analytica Influence the Brexit Vote and the US Election. Guardian, March 4, 2017.

EMBER, S. \& GRYNBAUM, M. 2017. BuzzFeed Posts Unverified Claims on Trump, Igniting a Debate. New York Times, January 10, 2017.

ENNS, P., LAGODNY, J. \& SCHULDT, J. P. 2017. Understanding the 2016 US Presidential Polls: The Importance of Hidden Trump Supporters. Statistics, Politics and Policy, 8, 4163.

ENTEN, H. 2016. There Were No Purple States on Tuesday. FiveThirtyEight, November 10, 2016.

ENTOUS, A., BARRETT, D. \& HELDERMAN, R. 2017a. Clinton Campaign, DNC Paid for Russia Dossier. Washington Post, October 24, 2017.

ENTOUS, A., NAKASHIMA, E. \& MILLER, G. 2016. Secret CIA Assessment Says Russia Was Trying to Help Trump Win White House. Washington Post, December 9, 2016.

ENTOUS, A., TIMBERG, C. \& DWOSKIN, E. 2017b. Obama Tried to Give Zuckerberg A Wake-Up Call on Fake News on Facebook. Washington Post, September 24, 2017.

ENTOUS, A., TIMBERG, C. \& DWOSKIN, E. 2017c. Russian Operatives Used Facebook Ads To Exploit Divisions Over Black Political Activism and Muslims. Washingon Post, September 25, 2017.

EPSTEIN, G. \& MONTECINO, J. A. 2016. Overcharged: The High Cost of High Finance. Roosevelt Institute.

FARENTHOLD, D. A. 2017. After Crowdsourced Investigation, Trump Inaugural Committee Admits There Were Errors in Its Donor List. Washington Post, April 25, 2017.

FARIS, R., ROBERTS, H., ETLING, B., BOURASSA, N., ZUCKERMAN, E. \& BENCHLER, Y. 2017. Partisanship, Propaganda, and Disinformation: Online Media and the U.S. Presidential Election. Berkman Klein Center: Harvard University.

FERGUSON, T. 1995a. Golden Rule: The Investment Theory Of Party Competition And The Logic Of Money-Driven Political Systems, Chicago, University of Chicago Press.

FERGUSON, T. 1995b. Party Realignment and American Industrial Structure: The Investment Theory of Political Parties in Historical Perspective. Golden Rule: The Investment Theory of Party Competition and the Logic of Money-Driven Political Systems. Chicago: University of Chicago Press.

FERGUSON, T. 2005. Holy Owned Subsidiary: Globalization, Religion, and Politics in the 2004 Election. In: CROTTY, W. (ed.) A Defining Election: The Presidential Race of 2004. Armonk, N.Y.: M.E. Sharpe.

FERGUSON, T. 2014a. Big Money, Mass Media, and the Polarization of Congress. In: CROTTY, W. (ed.) Polarized Politics: The Impact of Divsiveness in the US Political System. Boulder: Lynne Rienner Books.

FERGUSON, T. 2014b. What's the Real Reason "Capital in the 21 st Century Is Doing So Well in the United States? AlterNet, May 16, 2014.

FERGUSON, T. \& JOHNSON, R. 2009a. Too Big To Bail: The 'Paulson Put,' Presidential Politics, and the Global Financial Meltdown, Part I: From Shadow Banking System To Shadow Bailout, Part I. International Journal of Political Economy, 38, 3-34.

FERGUSON, T. \& JOHNSON, R. 2009b. Too Big To Bail: The "Paulson Put," Presidential Politics, and the Global Financial Meltdown Part II: Fatal Reversal- Single Payer and Back. International Journal of Political Economy, 38, 5-45. 
FERGUSON, T. \& JOHNSON, R. 2011. A World Upside Down? Deficit Fantasies in the Great Recession. International Journal of Political Economy, 40, 3-47.

FERGUSON, T., JORGENSEN, P. \& CHEN, J. 2013. Party Compeititon and Industrial Structure in the 2012 Elections. International Journal of Political Economy, 42, 3-41.

FERGUSON, T., JORGENSEN, P. \& CHEN, J. 2016. How Money Drives US Congressional Elections. Institute for New Economic Thinking, Working Paper \#48. On the web at https://papers.ssrn.com/sol3/papers.cfm?abstract id=2817705

FERGUSON, T., JORGENSEN, P. \& CHEN, J. 2017. Fifty Shades of Green: High Finance, Political Money, and the US Congress. New York: Roosevelt Institute. On the web at: http://rooseveltinstitute.org/wp-content/uploads/2017/05/FiftyShadesofGreen 0517.pdf

FERGUSON, T. \& PAGE, B. 2017. The Hinge of Fate: Economic and Social Populism in the 2016 Election. Institute For New Economic Thinking. Edinburgh Conference.

FERGUSON, T. \& ROGERS, J. 1986. Right Turn: The Decline Of The Democrats And The Future of American Politics, New York, Hill \& Wang.

FOWLER, E. F., RIDOUT, T. \& FRANZ, M. 2016. Political Advertising in 2016: The Presidential Election As Outlier? The Forum, 14, 445-69.

GELLER, E. 2016. Emails Show Powell Unloading on Clinton, Rumsfeld and Trump. Politico, September 14, 2016.

GELMAN, A. 2016. 19 Things We Learned From the 2016 Election. Statistical Modeling, Causal Inference, and Social Science. December 8, 2016.

GERSCHENKRON, A. 1962. Economic Backwardness in Historical Perspective, Cambridge, Harvard University Press.

GERSCHENKRON, A. 1966. Bread and Democracy in Germany, New York, Howard Fertig.

GIORDANO, D. 2017. Giordano: IBEW On Board With Trump. Daily News Philly.com, February 1, 2017.

GLAESER, E. 2011. Triumph of the City, New York, Penguin.

GOLD, M. 2016. The Rise of GOP Mega-Donor Rebekah Mercer. Washington Post, September $16,2017$.

GOLD, M. \& DWOSKIN, E. 2017. Trump Campaign's Embrace of Facebook Shows Company's Growing Reach in Elections. Washington Post, October 8, 2017.

GOODWYN, L. 1976. Democratic Promise, New York, Oxford University Press.

GRASSEGER, H. \& KROGERUS, M. 2016. Ich Habe Nur Gezeigt dass Es Die Bombe Gibt. Das Magazin, December 3, 2016, No. 48.

GREEN, J. 2017. Devil's Bargain -- Steve Bannon, Donald Trump, and the Storming of the Presidency, New York, Penguin.

GREENWALD, G. 2017. Yet Another Major Russia Story Falls Apart: Is Skepticism Permissible Yet? The Intercept, September 28, 2017.

GUO, J. 2016. Death Predicts Whether People Will Vote For Donald Trump. Washington Post, March 4, 2016.

HAJNAL, Z., LAJEVARDI, N. \& NIELSON, L. 2017. Voter Identification Laws and the Suppression of Minority Votes. Journal of Politics, 79.

HARDING, L., KIRCHGAESSENER, S. \& HOPKINS, N. 2017. British Spies Were First to Spot Trump Team's Links to Russia. Guardian, April 13, 2017.

HARRIS, S. 2016. Ahead in the Polls, Hillary Clinton Embraces GOP Neocon War Hawks: Interview With Robert Parry. Between The Lines, August 27, 2016. 
HELDERMAN, R., HAMBURGER, T. \& RICH, S. 2015. Clintons' Foundation Has Raised Nearly \$2 Billion -- And Some Key Questions. Washington Post, February 18, 2015.

HIRSCH, B. T. \& MACHPHERSON, D. A. 2017. Union Membership and Coverage Database From the CPS. Unionstats.com.

HIRSCHMAN, A. O. 1970. Exit, Voice, and Loyalty, Cambridge Harvard University Press.

HOWARD, P. N., KOLLANYI, B., BRADSHAW, S. \& NEUDERT, L.-M. 2017. Social Media, News, and Political Information During the US Election: Was Polarizing Content Concentrated in Swing States? Comprop Data Memo 2017.8. Oxford Oxford University.

INTELLIGENCE, O. O. T. D. O. N. 2017. Assessing Russian Activities and Intentions in Recent US Elections. Intelligence Community Assessment. Washington, D.C.: Office of the Director of National Intelligence.

ISAAC, M. \& SHANE, S. 2017. Facebook's Russia-Linked Ads Came in Many Disguises. New York Times, October 2, 2017.

ISENSTADT, A. 2016. Panicked GOP Makes Major Last-Minute Senate Investment. Politico, October 25, 2016.

JACOBSON, G. 2015. Obama and Nationalized Electoral Politics in the 2014 Midterm. Political Science Quarterly, 130, 1-25.

JOHNSON, A. 2016. Washington Post Ran 16 Negative Stories on Bernie Sanders in 16 Hours. FAIR.org, March 8, 2016.

KARNI, A. 2016. Inside Clinton's GOP Recruitment Plan. Politico, August 9, 2016.

KAYE, K. 2016. Trump Camp and RNC Say This Facebook Onslaught Was Risky. Ad Age, September 26, 2016.

KEHR, E. 1977. Economic Interest, Militarism, and Foreign Policy, Berkeley, University of Califiornia Press.

KEHR, E. 2012. Schlachtflottenbau und Parteipolitik 1894-1901, Paderborn, CT SalzwasserVerlag GmbH \& Company. KG.

KOWALJOW, A. 2017. So Schokiert von Trump Wie Alle Anderen. Die Zeit, January 20, 2017.

KRANISH, M. \& FISHER, M. 2016. Trump Revealed, New York, Simon \& Schuster.

KREISS, D. \& MCGREGOR, S. 2017. Forget Russian Trolls: Facebook's Own Staff Helped Win the Election. Buzzfeed, October 3, 2017.

KRINER, D. L. \& SHEN, F. X. 2017. Battlefield Casualties and Ballot Box Defeat: Did the Bush Obama Wars Cost Clinton the White House? SSRN.

KURTH, J. 1984. The Political Consequences of the Product Cycle: Industrial History and Political Outcomes. International Organization, 33, 1-34.

KUTTNER, R. 2017. Steve Bannon, Unrepentent. American Prospect, August 16, 2017.

LAZONICK, W. 2009. Sustainable Prosperity in the New Economy: Business Organization and High Tech Employment in the United States, Kalamazoo, Upjohn Institute.

LAZONICK, W. 2016. The Value Extracting CEO: How Executive Stock-Based Pay Undermines Investment in Productive Capabilities. New York: Institute for New Economic Thinking. Working Paper No. 54.

LAZONICK, W. 2017. The Functions of the Stock Market and the Fallacies of Shareholder Value. New York: Institute for New Economic Thinking. Working Paper No. 58.

LEOPOLD, J., CORMIER, A. \& GARRISON, J. 2017. Secret Finding: 60 Russian Payments "To Finance Election Campaign of 2016". BuzzFeed, November 14, 2017.

LICHTBLAU, E. 2017. The CIA Had Evidence of Russian Effort to Help Trump Earlier Than Believed. New York Times, April 6, 2017. 
LICHTBLAU, E. \& MEYERS, S. L. 2016. Investigating Donald Trump, F.B.I. Sees No Clear Link to Russia. New York Times, October 31, 2016.

LINSKEY, A. 2016. As A Senator, Hillary Clinton Was Hands Off On Wall Street. Boston Globe, January 17, 2016.

LOBIANCO, T. 2017. First on CNN: House Russia Investigators Want to Bring In Trump Digital Director. CNN.com, June 16, 2017.

LUBOLD, G. \& HARRIS, S. 2017. Russian Hackers Stole NSA Data On U.S. Cyber Defense. Wall Street Journal, October 5, 2017.

MADRIGAL, A. 2017. 15 Things We Learned From the Tech Giants at the Senate Hearings. The Atlantic, November 2, 2017.

MARCUS, R. 2017. Hillary Clinton, Smash Your Rearview Mirror. Washington Post, June 2, 2017.

MILlER, G., NAKASHIMA, E. \& ENTOUS, A. 2017. Obama's Secret Struggle to Punish Russia for Putin's Election Assault. Washington Post, June 23, 2016.

MITCHELL, A., GOTFRIED, J., BARTHEL, M. \& SHEARER, E. 2016. Trust and Accuracy. Washington, D.C.: Pew Research Center.

MONEY, C. 2017. The Fake News Machine: Inside A Town Gearing Up for 2020.

MONNAT, S. \& BROWN, D. 2017. Deaths of Despair and Support For Trump in the 2016 Presidential Election. Journal of Rural Studies, 55, 227-36.

PATTERSON, T. 2016a. News Coverage of the 2016 General Election: How the Press Failed the Voters. Shorenstein Center on Media, Politics, and Public Policy, December 7, 2016.

PATTERSON, T. 2016b. Pre-Primary News Coverage of the 2016 Race: Trump's Rise, Sanders' Emergence, Clinton's Struggle. Shorenstein Center on Media, Politics, and Public Policy, June 13, 2016.

PHILLIPS-FEIN, K. 2009. Invisible Hands, New York, W.W. Norton.

QUIGLEY, A., 2017. Podesta: 'Forces Within the FBI May Have Cost Clinton the Election, February 21, 2017.

RHODE, P. W. \& STRUMPF, K. 2004. Historical Presidential Betting Markets. Journal of Economic Perspectives, 18, 127-42.

RHODE, P. W. \& STRUMPF, K. 2007. Manipulating Political Stock Markets: A Field

Experiment and a Century of Observational Data. Available: http://www.unc.edu/ cigar/papers/ManipNBER.pdf [Accessed July 15, 2016].

RHODE, P. W. \& STRUMPF, K. 2008. Historical Political Futures Markets: An International Perspective. [Accessed July 14, 2016].

RITTER, S. 2017. Time to Reassess the Roles Played By Guccifer 2.0 and Russia in the DNC Hack Truth Dig, July 28, 2017.

ROGERS, K. 2017. Ignored By Big Telecom, Detroit's Marginalized Communities Are Building Their Own Internet. Motherboard.vice.com.

ROSENBERG, A. 1939. Democracy and Socialism, New York, Knopf.

ROSENBERG, A. 1991. Geschichte der Weimarer Republik, Hamburg, Europaeische Verlagsanstalt

RUFFINI, P. 2017. Why Russia's Facebook Campaign Wasn't Such A Success. Washington Post, November 3, 2017.

SACHS, J. 2016. Hillary Is the Candidate of the War Machine. Huffington Post, February 5, 2016. 
SATTER, R., DONN, J. \& DAY, C. 2017. Inside Story: How the Russians Hacked the Democrats' Emails. APNews.com, November 4, 2017.

SCHWARTZ, N. 2017. Trade Worries Led Wisconsin Mill Town to Trump. It's Still Uneasy. New York Times, November 24, 2017.

SCHWEITZER, P. 2015. Clinton Cash, New York, HarperCollins.

SHEPHERDSON, D. 2017. Trump Meets With Leaders of Building, Sheet Metal Unions. Reuters, January 23, 2017.

SHERMAN, G. 2016. How Paul Manafort Took Over the Trump Campaign. New York Magazine, April 19, 2016.

SIDES, J. 2016. Five Key Lessons From Donald Trump's Surprising Victory. Washington Post, November 9, 2017.

STAFF, N. C. 2016. Donald Trump, Speech, Debate and Campaign Quotes. Newsday.com, November 9, 2016.

STORM, S. 2017. The New Normal: Demand, Secular Stagnation, and the Vanishing Middle Class. New York: Institute for New Economic Thinking. Working Paper No. 55.

STURGIS, S. 2017. Paul Manafort's Role in the Republican's Notorious "Southern Strategy". Truthout, November 8, 2017.

SUBRAMANIAN, S. 2017. Fake: Inside the Macedonian Fake News Complex. Wired, February $15,2017$.

SULLIVAN, S. 2016. Trump Hires Ex-Cruz Super Pac Strategist Kellyanne Conway. Washington Post, July 1, 2016.

SWANN, S. 2017. The Politics Behind Your College and How You Pay For It. OpenSecrets.org, August 8, 2017.

TEMIN, P. 2015. The American Dual Economy: Race, Globalization, and the Politics of Exclusion. New York: Institute for New Economic Thinking. Working Paper No. 26.

TEMIN, P. 2016. Race and the Vanishing Middle Class, Cambridge, MIT Press.

TIMBERG, C. 2017. Russian Propaganda May Have Been Shared Hundreds of Millions of Times New Research Says. Washington Post, October 5, 2017.

TIMES, N. Y. 2017. Correction: June 29, 2017. New York Times, June 29, 2017.

TROYAN, M. \& SCHOUTEN, F. 2016. Mitch McConnell's Late Fundraising "Flare" Raised Millions for Senate Races. USA Today, November 10, 2016.

TRUDO, H. and VOGEL, K., 2016. Convicted Ponzi Schemer: I'll Conduct \$50 Million Marketing Campaign for Trump. Politico, June 16, 2016.

UCHILL, J. 2016. Report: Russia Tried to Start Own Wikileaks. The Hill, August 12, 2016.

VOGEL, K. \& GOODSTEIN, L. 2017. In Tax Debate, Gift to Religious Right Could Be Bargaining Chip. New York Times, November 26, 2017.

VOGEL, K. \& HABERMAN, M. 2017. Conservative Website First Funded Research That Later Produced Dossier. New York Times, October 27, 2017.

VOGEL, K. \& SAMUELSOHN, D. 2016. Trump's Secret Data Reversal. Politico, June 28, 2016.

VOGEL, K. \& STERN, D. 2017. Ukrainian Efforts to Sabatoge Trump Backfire. Politico, January 11, 2017.

WEIL, D. 2017. The Fissured Workplace: , Cambridge, Harvard University Press.

WHEELER, M. 2016. The Obamacare Not Comey Effect. The Empty Wheel, December 11, 2016. 
WHEELER, M. 2017a. Facebook Anonymously Admits It Id'd Guccifer 2.0 in Real Time. The Empty Wheel, September 24, 2017.

WHEELER, M. 2017b. We Have No Idea What Emails the Papadopoulos Emails Refer To. The Empty Wheel, October 31, 2017.

WINES, M. 2016. Some Republicans Acknowledge Leveraging Voter ID Laws For Political Gain. New York Tiimes, September 16, 2016.

YOON, R. 2016. \$153 Million in Bill and Hillary Clinton Speaking Fees, Documented. CNN, Februrary 6, 2016.

ZONTA, M., EDELMAN, S. \& MCARTHUR, C. 2016. The Role of Midwestern Housing Instability in the 2016 Election. Washington, D.C.: Center for American Progress. 


\section{Notes}

${ }^{1}$ In a vast literature, see, e.g., JACOBSON, G. 2015. Obama and Nationalized Electoral Politics in the 2014

Midterm. Political Science Quarterly, 130, 1-25.

2 See, e.g., NBC News, “Trump Ad Invokes Anti-Semitic Tropes,” Nov. 6, 2016;

https://www.nbcnews.com/card/anti-defamation-league-trump-ad-invokes-anti-semitic-tropes-n678686 ; accessed September 19, 2017.

${ }^{3}$ The speech was widely available; our citation comes from https://egbertowillies.com/2016/06/29/donald-trumpspeech-in-monessen-pennsylvania-video-transcript/

${ }^{4}$ Books and articles on the election are proliferating. For basic references, see, e.g., ALLEN, J. \& PARNES, A. 2017. Shattered -- Inside Hillary Clinton's Doomed Campaign, New York, Crown; and GREEN, J. 2017. Devil's Bargain -- Steve Bannon, Donald Trump, and the Storming of the Presidency, New York, Penguin.

5 These results come from the CNN website compilation, "2016 Election Results,"

http://www.cnn.com/election/results

${ }^{6}$ For Trump meetings with union leaders, see, e.g., SHEPHERDSON, D. 2017. Trump Meets With Leaders of Building, Sheet Metal Unions. Reuters, January 23, 2017. January 23, 2017; GIORDANO, D. 2017. Giordano: IBEW On Board With Trump. Daily News Philly.com, February 1, 2017., February 1, 2017.

${ }^{7}$ ALLEN, J. \& PARNES, A. 2017. Shattered -- Inside Hillary Clinton's Doomed Campaign, New York, Crown.

${ }^{8}$ Ibid. See also the account by Hillary Clinton herself: CLINTON, H. 2017. What Happened, New York, Simon \& Schuster. How the emails got to Wikileaks has been hotly contested; Julian Assange has denied that WikiLeaks obtained them from Russia. US government sources insist they did, directly or indirectly. A particularly interesting account is SATTER, R., DONN, J. \& DAY, C. 2017. Inside Story: How the Russians Hacked the Democrats' Emails. APNews.com, November 4, 2017. A problem is that when the breach was discovered, the Democratic National Committee did not allow the government agencies direct access to its servers. Instead the agencies relied on the judgment of a private security firm hired by the DNC. See the discussion below, but especially RITTER, S. 2017. Time to Reassess the Roles Played By Guccifer 2.0 and Russia in the DNC Hack Truth Dig, July $28,2017$. Our discussion here treats the "Podesta Emails" in a conventional sense. Note that Marcy Wheeler and other analysts have cautioned against assuming that we truly understand how many emails from various actors were accessed or exactly when they leaked. There is strong evidence, for example, that some of the so-called "Podesta Emails" were leaked long before October, 2016, including some in batches that have usually been attributed to hacks on the Democratic National Committee. See the discussion and references in WHEELER, M. 2017b. We Have No Idea What Emails the Papadopoulos Emails Refer To. The Empty Wheel, October 31, 2017.

Note that the Podesta emails were but one of many security breaches now under discussion, including many at state election boards and that we quite accept that some forms of Russian interference during the election happened. As will become clearer below, the question is how much they mattered, with so many other actors also bent on changing minds via the internet.

${ }^{9}$ For accounts of behind the scenes infighting, see, e.g., LICHTBLAU, E. 2017. The CIA Had Evidence of Russian Effort to Help Trump Earlier Than Believed. New York Times, April 6, 2017. An earlier report was ENTOUS, A., NAKASHIMA, E. \& MILLER, G. 2016. Secret CIA Assessment Says Russia Was Trying to Help Trump Win White House. Washington Post, December 9, 2016.

${ }^{10}$ Office of the Director of National Intelligence, “Assessing Russian Activities and Intentions in Recent US Elections. Washington, D.C. https:/www.dni.gov/files/documents/ICA 2017 01.pdf

${ }^{11}$ On the compartmentalized process that generated the report, see, above all, MILLER, G., NAKASHIMA, E. \& ENTOUS, A. 2017. Obama's Secret Struggle to Punish Russia for Putin's Election Assault. Washington Post, June 23, 2016, BRENNAN, J. 2017. House Intel Committee Hearing; Brennan on Contact with Russia. CNN Transcripts, May 23, 2017. The differences in accounts of the process are clearly outlined in RITTER, S. 2017. Time to Reassess the Roles Played By Guccifer 2.0 and Russia in the DNC Hack Truth Dig, July 28, 2017. See also the rather late acknowledgement of the facts in TIMES, N. Y. 2017. Correction: June 29, 2017. New York Times, June $29,2017$.

12 Office of the Director of National Intelligence, "Assessing Russian Activities and Intentions in Recent US Elections. Washington, D.C. https://www.dni.gov/files/documents/ICA 2017 01.pdf

13 EMBER, S. \& GRYNBAUM, M. 2017. BuzzFeed Posts Unverified Claims on Trump, Igniting a Debate. New York Times, January 10, 2017. For the European intelligence agencies, see, e.g., HARDING, L., 
KIRCHGAESSENER, S. \& HOPKINS, N. 2017. British Spies Were First to Spot Trump Team's Links to Russia. Guardian, April 13, 2017. For the DNC and Ukraine, see VOGEL, K. \& STERN, D. 2017. Ukrainian Efforts to Sabatoge Trump Backfire. Politico, January 11, 2017. January 11, 2017.

${ }^{14}$ Since the election, an enormous literature has grown up on data firms associated with the Trump campaign and also, in some cases, perhaps with Brexit. Much of the attention centers on Cambridge Analytica. GREEN, J. 2017. Devil's Bargain -- Steve Bannon, Donald Trump, and the Storming of the Presidency, New York, Penguin., pp. 13435 describes it as an "off shoot" of a British company, Strategic Communication Laboratories (SCL). Green identifies Robert Mercer as the latter's "principal owner" but adds that Steve Bannon also had an ownership stake and a seat on the board. All sorts of claims have been made about what are said to be breakthroughs in election and opinion manipulation by psychologists associated with SCL or Cambridge Analytica. A story in the Zurich based Das Magazin shortly after the election attracted worldwide attention. GRASSEGER, H. \& KROGERUS, M. 2016. Ich Habe Nur Gezeigt dass Es Die Bombe Gibt. Das Magazin, December 3, 2016, p.No. 48. The literature is too vast to discuss here, though we will touch upon it below. A series of articles on the companies published in the Guardian introduced many of these themes into English. SCL and Cambridge Analytica have disputed certain claims of these. See DOWARD, J. \& GIBBS, A. 2017. Did Cambridge Analytica Influence the Brexit Vote and the US Election. Guardian, March 4, 2017.March 4, 2017 https:/www.theguardian.com/politics/2017/mar/04/nigel-oakes-

cambridge-analytica-what-role-brexit-trump; CADWALLADR, C. Robert Mercer: The Big Data Billionaire Waging War on Mainstream Media. February 26, 2017. Feb. 26, 2017;

https://www.theguardian.com/politics/2017/feb/26/robert-mercer-breitbart-war-on-media-steve-bannon-donaldtrump-nigel-farage ; and CADWALLADR, C. 2017a. The Great British Brexit Robbery: How Our Democracy Was Hijacked. Guardian, May 7, 2017. May 7, 2017, https:/www.theguardian.com/technology/2017/may/07/the-greatbritish-brexit-robbery-hijacked-democracy

${ }^{15}$ See, e.g., DE PLOEG, C. K. 2017. Ukraine in the Crossfire, Atlanta, Clarity Press.

${ }^{16}$ INTELLIGENCE, O. O. T. D. O. N. 2017. Assessing Russian Activities and Intentions in Recent US Elections. Intelligence Community Assessment. Washington, D.C.: Office of the Director of National Intelligence.

${ }^{17}$ The literature is now very large, with some pollsters continuing to maintain that polls remain slightly superior. See, e.g., RHODE, P. W. \& STRUMPF, K. 2008. Historical Political Futures Markets: An International Perspective. [Accessed July 14, 2016]. RHODE, P. W. \& STRUMPF, K. 2004. Historical Presidential Betting Markets. Journal of Economic Perspectives, 18, 127-42, RHODE, P. W. \& STRUMPF, K. 2007. Manipulating Political Stock Markets: A Field Experiment and a Century of Observational Data. Available on the web:

http://www.unc.edu/ cigar/papers/ManipNBER.pdf [Accessed July 15, 2016]. Of course the outstanding feature of the last several years has been the degree to which both polls and betting markets got things wrong, which does not negate the point about private information here.

${ }^{18}$ This point seems to be lost in the discussion in the US; it is not omitted in Europe. See the piece by a strong critic of the current Russian regime in Die Zeit: KOWALJOW, A. 2017. So Schokiert von Trump Wie Alle Anderen. Die Zeit, January 20, 2017. Jan. 20, 2017 http://www.zeit.de/politik/ausland/2017-01/russland-donald-trump-wahlsiegueberraschung-manipulation-wladimir-putin

${ }^{19}$ QUIGLEY, A., 2017. Podesta: 'Forces Within the FBI May Have Cost Clinton the Election, February 21, 2017; CLINTON, H. 2017. What Happened, New York, Simon \& Schuster.

${ }^{20}$ The literature here is very large, but see on DC Leaks, e.g., UCHILL, J. 2016. Report: Russia Tried to Start Own Wikileaks. The Hill, August 12, 2016. DC Leaks published some material from various Republican sources and also treated many topics that clearly had no connection with the election. Its relation to Guccifer 2.0 has been widely debated.

${ }^{21}$ ALLEN, J. \& PARNES, A. 2017. Shattered -- Inside Hillary Clinton's Doomed Campaign, New York, Crown. The claim relates to comments about Catholics by two Catholics in the Clinton campaign. We are skeptical; if Clinton had trouble with Catholics, her campaign was its own worst enemy. When she refused an invitation to speak at Notre Dame University, the campaign explained that "white Catholics were not the audience she needed to spend time reaching out to"; CHOZICK, A. 2016. Hillary Clinton's Expectations, and Her Ultimate Campaign Missteps. New York Times, November 9, 2016.

In her book, Clinton cites Appleton, Wisconsin as a place where searches were especially high. This is actually an area that has been badly hurt by the erosion of the US paper industry; see SCHWARTZ, N. 2017. Trade Worries Led Wisconsin Mill Town to Trump. It's Still Uneasy. Ibid., November 24, 2017. We examined Google Trends for "Podesta Emails" and "Podesta Emails Wikileaks" from April 15, 2016 to December 31; Wisconsin's score was a very low 41, where 100 registered highest. We could not examine individual towns, but the site indicates the highest levels in the state came in the areas around Madison and Milwaukee. See CLINTON, H. 2017. What Happened, 
New York, Simon \& Schuster. It is only fair to note that slight differences in timing or exact search terms (whether one adds Wikileaks, for example) can affect results, though not substantially in our experience.

${ }^{22}$ See for the strong claims, e.g., BORGER, J. 2017. Investigators Explore If Russian Colluded With Pro-Trump Sites During Election. Guardian, July 5, 2017; CLINTON, H. 2017. What Happened, New York, Simon \& Schuster.

${ }^{23}$ We are grateful to Roger Trilling for making this point to us. For an example, see LUBOLD, G. \& HARRIS, S. 2017. Russian Hackers Stole NSA Data On U.S. Cyber Defense. Wall Street Journal, October 5, 2017.

${ }^{24}$ An incisive discussion is WHEELER, M. 2017a. Facebook Anonymously Admits It Id'd Guccifer 2.0 in Real Time. The Empty Wheel, September 24, 2017.

${ }^{25}$ See the discussion in TIMBERG, C. 2017. Russian Propaganda May Have Been Shared Hundreds of Millions of Times New Research Says. Washington Post. The study, by Jonathan Albright, posted on Tableau Public, is here: https://public.tableau.com/profile/d1gitt!/vizhome/FB4/TotalReachbyPage On the question of readers effects, see the discussion below of ALLCOTT, H. \& GENTZKOW, M. 2017. Social Media and Fake News in the 2016 Election. Journal of Economic Perspectives, 31, 211-36. For the Congressional testimony, see especially MADRIGAL, A. 2017. 15 Things We Learned From the Tech Giants at the Senate Hearings. The Atlantic, November 2, 2017.

${ }^{26}$ Note that Breitbart is strongly pro-Israel, as the site explained repeatedly in the wake of Charlottesville. Steve Bannon's own movies are also quite sympathetic to African-American problems. But these facts hardly exhaust Breitbart or Bannon's relationships to the substantial segment of the far right that is openly anti-Semitic and white supremacist. See BERNSTEIN, J. 2017. Alt-White: How the Breitbart Machine Laundered Racist Hate. BuzzFeed, October 5, 2017. Cf. also the discussion in GREEN, J. 2017. Devil's Bargain -- Steve Bannon, Donald Trump, and the Storming of the Presidency, New York, Penguin.

${ }^{27}$ ALBRIGHT, J. 2017b. Who Hacked the Election? Ad Tech Did. Through "Fake News," Identity Resolution, and Hyper-Personalization. Medium, July 31, 2017.

${ }^{28}$ See also HAJNAL, Z., LAJEVARDI, N. \& NIELSON, L. 2017. Voter Identification Laws and the Suppression of Minority Votes. Journal of Politics, 79. BENTELE, K. \& O'BRIEN, E. 2013. Jim Crow 2.0? Why States Consider and Adopt Restrictive Voter Access Policies. Perspectives on Politics, 11, 1088-1116.

${ }^{29}$ We do not mean to suggest that some state and local authorities were not hacked; that seems plain, but situations like those Greenwald details in his account do not help by exaggeration. State and federal authorities should be compelled to coordinate their claims and resolve differences for basic credibility.

${ }^{30}$ Claims that Macedonians were heavily engaged by Russian agents to work on behalf of Trump, for example, look grossly exaggerated. In a city acknowledged to be a center of internet trolling, a reporter for Wired found free enterprise - money for clicks on sites - driving the process. SUBRAMANIAN, S. 2017. Fake: Inside the Macedonian Fake News Complex. Wired, February 15, 2017. So did CNN Money. MONEY, C. 2017. The Fake News Machine: Inside A Town Gearing Up for 2020.

${ }^{31}$ Note that there is no claim that all that attempts at rallies do is stimulate searches; we simply accept the now common research idea that many internet operations can be at least imperfectly checked by studying trends in search behavior.

${ }^{32}$ BOXELL, L., GENTZKOW, M. \& SCHAPIRO, J. M. 2017. Is the Internet Causing Political Polarization? Evidence From Demographics.

${ }^{33}$ For the announcement of the increases, see $h t t p: / / m o n e y . c n n . c o m / 2016 / 10 / 24 /$ news/economy/obamacarepremiums/index.html; WHEELER, M. 2016. The Obamacare Not Comey Effect. The Empty Wheel, December 11, 2016. This has a convenient figure with some dates, though the shape of the figure is precisely what the arguments about averaging are about. For Bill Clinton, ALLEN, J. \& PARNES, A. 2017. Shattered -- Inside Hillary Clinton's Doomed Campaign, New York, Crown.

${ }^{34}$ There is of course the possibility that something leaked; it could be either polls, which in our experience leak like sieves and definitely move markets; or someone with knowledge of Comey's deliberations, which would underscore Podesta's point cited earlier.

${ }^{35}$ We expect to update our earlier FERGUSON, T., JORGENSEN, P. \& CHEN, J. 2016. How Money Drives US Congressional Elections. Institute for New Economic Thinking, Working Paper \#48; and will analyze the Congressional wave in detail there.

${ }^{36}$ ENNS, P., LAGODNY, J. \& SCHULDT, J. P. 2017. Understanding the 2016 US Presidential Polls: The Importance of Hidden Trump Supporters. Statistics, Politics and Policy, 8, 41-63. Compare Trump's showing in various state polls with surveys of Senate races in the course of building an interesting case for the notion of a submerged pro-Trump vote that polls largely missed. We lack the space to take up their main arguments here and can only state some key points relevant to our own discussion. Firstly, we are not as impressed by the customary 
arguments in favor of unchanging preferences that motivates their paper. 2016 was so extraordinary that we find it hard to believe that substantial numbers of voters were not in fact wavering. We interpret their findings as really about a class of so-called "leaners." If viewed in those terms the role of a wave of political money becomes straightforward, but that is a longer discussion. We would note that the parallel changes in the Senate and Presidential campaigns that we discuss here do not imply that the different campaigns start from the same levels; they simply change in the aggregate. That is our point.

${ }^{37}$ During the campaign, Trump reportedly committed to repealing the 1954 Johnson Amendment, which bans churches and some other non-profits from engaging in political activity VOGEL, K. \& GOODSTEIN, L. 2017. In Tax Debate, Gift to Religious Right Could Be Bargaining Chip. New York Times, November 26, 2017.

${ }^{38}$ CADWALLADR, C. 2017a. The Great British Brexit Robbery: How Our Democracy Was Hijacked. Guardian, May 7, 2017. as well as the literature cited in above. Note that many of the claims advanced about the firm's methods appear to be over-hyped. BARAJAS, M. 2016. "Project Alamo": Lessons From Inside Trump's SA-Based Digital Nerve Center. San Antonio Current, October 27, 2017.

${ }^{39}$ See also SIDES, J. 2016. Five Key Lessons From Donald Trump's Surprising Victory. Washington Post, November 9, 2017.

${ }^{40} \mathrm{Kehr}$ and Rosenberg wrote their classic works mostly in the interwar period. See, e.g., KEHR, E. 2012. Schlachtflottenbau und Parteipolitik 1894-1901, Paderborn, CT Salzwasser-Verlag GmbH \& Company. KG; KEHR, E. 1977. Economic Interest, Militarism, and Foreign Policy, Berkeley, University of Califiornia Press. ROSENBERG, A. 1991. Geschichte der Weimarer Republik, Hamburg, Europaeische Verlagsanstalt; ROSENBERG, A. 1939. Democracy and Socialism, New York, Knopf. A generation later, the approach returned, mostly at the hands of authors from the right, rather than the left. See in particular, GERSCHENKRON, A. 1966.

Bread and Democracy in Germany, New York, Howard Fertig; GERSCHENKRON, A. 1962. Economic Backwardness in Historical Perspective, Cambridge, Harvard University Press. Among Kurth's works, see especially KURTH, J. 1984. The Political Consequences of the Product Cycle: Industrial History and Political Outcomes. International Organization, 33, 1-34.

${ }^{41}$ The possible errors and limitations in these codes need to be borne in mind, as outlined in our 2013 article. Though no system is perfect, we believe the big business assignments are of very high quality. In the much larger universe of smaller firms, the data likely become less reliable as firms get smaller and smaller. An offset to that is that truly small firms account generally for very little money.

In the data for 2016, we believe too many smaller firms show in the private equity classification; for many purposes that might better be added to the data for hedge funds and treated as a broader "finance" classification. By contrast the big business data for private equity, which figured importantly in the last stages of the Trump campaign, is of much higher reliability.

421896 is often considered to be an election which pitted populist farmers against a business community united around the Republican standard bearer. This is simply false; see the discussion in GOODWYN, L. 1976.

Democratic Promise, New York, Oxford University Press. The silver companies backing Bryan, an editor of a newspaper they supported, were among the largest firms in the United States - true giants, which is why they so easily brushed aside the genuine Populists. See the discussion in FERGUSON, T. 1995b. Party Realignment and American Industrial Structure: The Investment Theory of Political Parties in Historical Perspective. Golden Rule: The Investment Theory of Party Competition and the Logic of Money-Driven Political Systems. Chicago: University of Chicago Press.

${ }^{43}$ See also COSTANTINI, O. 2015. The Cyclically Adjusted Budget: The History and Exegesis of a Fateful Estimate. Institute for New Economic Thinking Working Paper No.24.; and the work by Antonella Palumbo and others cited therein.

${ }^{44}$ A fine set of statistics is produced regularly by the National Center for Children in Poverty at the Millman School of Public Health, Columbia University at http://www.nccp.org/publications/fact sheets.html

${ }^{45}$ See, e.g., Trade Union Density, OECD.Stat, https://stats.oecd.org/Index.aspx?DataSetCode=UN DEN

${ }^{46}$ So, of course, do studies that do not carefully track the actual experiences of districts with regard to plant

relocation and imports, which are quite different things.

${ }^{47} \mathrm{We}$ are grateful to Orsola Costantini for discussions as she prepares her own study of consumer debt.

${ }^{48}$ The discussion in the 2005 paper was truncated; the full version is available on the web as Working Paper \#32 of the University of Texas Inequality Project: http://utip.lbj.utexas.edu/papers/utip 32.pdf

${ }^{49}$ See the discussion in GELMAN, A. 2016. 19 Things We Learned From the 2016 Election. Statistical Modeling, Causal Inference, and Social Science, December 8, 2016.

${ }^{50}$ Thereafter we count money coming in for Trump as part of the general election; we also use that date as the cutoff point for beginning to count money to the Republican National Committee as money for Trump, parallel to our 
treatment of Obama and other presidential nominees in earlier years. Note that other reports of money in the election count all donations to anti-Clinton Super Pacs as pro-Trump. We do not until after this May date.

The relations between the Trump campaign and the RNC were the subject of many news articles, but it is clear that they in fact worked together quite closely. We count all money given to the Democratic National Committee as a contribution to the Clinton campaign; it was obvious from leaked emails long before Donna Brazile revealed details of the secret agreements between the DNC and the Clinton campaign that the latter controlled the committee. BRAZILE, D. 2017. Hacks, New York, Hachette.

${ }^{51}$ Note that when we speak of money coming from particular firms, unless otherwise indicated, we are using shorthand for an amalgamation of money from different sources: the executives of the firms who mostly donate in their own names, funds directly paid out by corporations (which do not go directly into campaign committees, but to nominally independent committees promoting candidates), contributions from firm political action committees, etc. The usage does not normally imply that contributions came in the name of the firm. See the discussion in FERGUSON, T., JORGENSEN, P. \& CHEN, J. 2013. Party Compeititon and Industrial Structure in the 2012 Elections: . International Journal of Political Economy, 42, 3-41. And FERGUSON, T. 1995a. Golden Rule: The Investment Theory Of Party Competition And The Logic Of Money-Driven Political Systems, Chicago, University of Chicago Press.

Those two sources also outline our system for making industrial sector assignments, which we carry over in this paper. Identifying firms below our cut offs for big business is inevitably tricky, because finding sectoral data becomes very difficult. When that is unavailable, some sectors, notably oil or steel, provide many clues in the names of many firms. But not all sectors do. It is inevitable that errors and omissions creep into the small firm statistics; for big firms, the problems are different. In those, the data is much easier to find, but sometimes can mislead.

${ }^{52}$ For the differences within the telecom sector in regard to network neutrality, see the discussion and references in FERGUSON, T., JORGENSEN, P. \& CHEN, J. 2017. Fifty Shades of Green: High Finance, Political Money, and the US Congress. New York: Roosevelt Institute.

${ }^{53}$ The local rescinded the invitation at the last minute under pressure from the national union. Trump came anyway and was welcomed by the local members. See the discussion in GREEN, J. 2017. Devil's Bargain -- Steve Bannon, Donald Trump, and the Storming of the Presidency, New York, Penguin.

${ }^{54}$ PATTERSON, T. 2016b. Pre-Primary News Coverage of the 2016 Race: Trump's Rise, Sanders' Emergence, Clinton's Struggle. Shorenstein Center on Media, Politics, and Public Policy, June 13, 2016, dismisses complaints about the media's coverage of Sanders, though conceding he was initially ignored. We think this is a mistake and that the study should have directly compared the treatment of Trump by the media with Sanders and looked more closely at the tone than the study did. Compare the many quantitative assessments of coverage on the website of Fairness and Accuracy in Reporting; for example, JOHNSON, A. 2016. Washington Post Ran 16 Negative Stories on Bernie Sanders in 16 Hours. FAIR.org, March 8, 2016.

${ }^{55}$ Total union contributions to Clinton before August 1, 2016 amounted to just under \$34 million dollars; total union contributions to Sanders totaled just over $\$ 5.4$ million. The number of individual union members contributing we can identify to each campaign is almost the same, running close to 450,000 for both. But there are many more organizational and political action contributions to the Clinton campaign from labor sources.

${ }^{56}$ Note that as we have stressed many times, two way causality between money and votes happens. But as we argued in detail in FERGUSON, T., JORGENSEN, P. \& CHEN, J. 2016. How Money Drives US Congressional Elections. Institute for New Economic Thinking, Working Paper \#48, money typically is the more important factor. The 2016 Senate results are an especially striking case in point, since the wave of Republican money that preserved the Senate came when their polls were strikingly unpromising. More of this in another paper.

${ }^{57}$ We repeat our caution above that mentioning firms is usually a shorthand for summarizing a wide variety of contributions, including from individual executives, not firms per se. The big Facebook contribution is something of a surprise, given the wave of publicity that insists that the firm was lopsidedly partial to Democrats. But we cannot explore this question here. It also came in the name of the firm.

${ }^{58}$ We have several times received queries about whether foreign money could be mixed into these numbers. Various unconfirmed reports swirling around also raise this question in a pointed fashion. See, e.g., LEOPOLD, J.,

CORMIER, A. \& GARRISON, J. 2017. Secret Finding: 60 Russian Payments "To Finance Election Campaign of 2016". BuzzFeed, November 14, 2017. We have run the obvious checks for eastern European names of people and companies, with no interesting results. Essentially all the very large transactions are relatively easy to trace and do not raise questions. An organized effort to channel many small contributions is possible, but there is no real way to rule something like that out. But our view is that to add appreciably to the fantastic sums clearly raised domestically, any such effort would have to so large it probably would surface. The sums bandied around 
speculatively in various news reports simply wouldn't make a real difference. The U.S. political system is moneydriven and needs no foreign intervention to reach that status.

One caution on Figure 4; one giant contribution in mid-June distorts it, even though we use a three day moving average. See the discussion in TRUDO, H. and VOGEL, K., 2016. Convicted Ponzi Schemer: I'll Conduct \$50 Million Marketing Campaign for Trump. Politico, June 16, 2016; this appears to have been carried out.

${ }^{59}$ See the discussion above on the relative reliability of the data on private equity; the point is that the big business data is likely quite good.

${ }^{60}$ The sources for this table are more complex than they should be. The Federal Election Commission, as this paper concludes, has a Committee ID number for a " $58^{\text {th }}$ Presidential Inaugural Committee." That ID isC00629584, but that takes you to a notice that there is as yet no data. There was at one time a pdf of the donors available, though not the electronic file that would be normal. We are not sure that the pdf is still available, but earlier we did acquire a copy and have used it for our tabulations along with the list compiled (presumably from that pdf) at Open Secrets: https://docs.google.com/spreadsheets/d/1MgxCjiw0niZxuSlfUEqbHpiLhrSL97XYOisgTzYbmVc/edit\#gid=899971 $\underline{993}$

We also consulted the crowd sourced compilation that Huffington Post organized; see FARENTHOLD, D. A. 2017. After Crowdsourced Investigation, Trump Inaugural Committee Admits There Were Errors in Its Donor List. Washington Post, April 25, 2017. This pointed to a series of names that were rather plainly fake.

${ }^{61}$ Which the American state also pursues heavily in various sectors; see the earlier discussion of state investment in electronics, pharmaceuticals, and others, above. 